\title{
WestVirginiaUniversity
}

THE RESEARCH REPOSITORY @ WVU

Graduate Theses, Dissertations, and Problem Reports

2007

\section{Analysis of motor activity of recombinant myosin-1c}

Anindita Biswas

West Virginia University

Follow this and additional works at: https://researchrepository.wvu.edu/etd

\section{Recommended Citation}

Biswas, Anindita, "Analysis of motor activity of recombinant myosin-1c" (2007). Graduate Theses,

Dissertations, and Problem Reports. 4291.

https://researchrepository.wvu.edu/etd/4291

This Thesis is protected by copyright and/or related rights. It has been brought to you by the The Research Repository @ WVU with permission from the rights-holder(s). You are free to use this Thesis in any way that is permitted by the copyright and related rights legislation that applies to your use. For other uses you must obtain permission from the rights-holder(s) directly, unless additional rights are indicated by a Creative Commons license in the record and/ or on the work itself. This Thesis has been accepted for inclusion in WVU Graduate Theses, Dissertations, and Problem Reports collection by an authorized administrator of The Research Repository @ WVU. For more information, please contact researchrepository@mail.wvu.edu. 


\title{
Analysis of motor activity of recombinant Myosin-1c
}

\author{
Anindita Biswas \\ Thesis submitted to the School of Medicine \\ at West Virginia University \\ in partial fulfillment of the requirements
}

for the degree of

Master of Science in

Biochemistry and Molecular Biology

\author{
Janet L. Cyr, Ph.D., West Virginia University; Committee chairperson \\ Ashok P. Bidwai, Ph.D., West Virginia University \\ Peter H. Mathers. Ph.D., West Virginia University \\ Maxim Sokolov, Ph.D., West Virginia University
}

Department of Biochemistry

Sensory Neuroscience Research Center

Morgantown, WV

2007

Keywords: Myo1c, Calmodulin, lever arm, ATPase assay, IQ domain, PCR sewing 


\section{Abstract \\ Analysis of motor activity of recombinant Myosin-1c}

Hair cells of the inner ear are responsible for hearing and balance. These hair cells are limited in number and do not regenerate following injury. To better appreciate the function of these cells it is important to understand the molecular basis of hearing and the roles of the various molecules involved in this process. The overall goal of our laboratory is to understand the molecular basis of mechanotransduction, a process that converts the mechanical sound wave to an electrical stimulus that is transmitted to the brain. We are specifically interested in the motor protein myosin-1c (Myo1c) that has been previously shown to be involved in the adaptation response, a process that makes the hair cells sensitive to prolonged stimulation. Myolc is a mechanoenzyme that uses the energy of ATP hydrolysis to power its movement along F-actin. The goal of this research is to examine the motor properties of Myolc, specifically the role of the neck region of the protein in its ATPase activity. Research with other myosins of the same class has elucidated the importance of the neck length of myosins in their enzyme activity and to date no such reports exist for Myo1c. In addition to hair cells, Myo1c is also expressed in other cell types, such as neurons and adipocytes in culture and is involved in motility and vesicle transport in these cells respectively. Thus understanding the regulation of Myolc function will also enable us to understand its role in various physiological processes. 


\section{Acknowledgements}

I would like to thank my advisor, Dr. Janet L. Cyr for all her help and guidance throughout my graduate study and in accomplishing this work. I greatly appreciate all her patience and the time she spent in teaching me how to write. I believe my thorough scientific training under her supervision will help me immensely in the future and for that I can never thank her enough.

I am grateful to my other committee members, Dr. Pete Mathers, Dr. Max Sokolov and Dr. Ashok Bidwai for their help and valuable suggestions.

I would also like to thank Dr. Stephen Graber for his help and suggestions with regard to experiments.

A special word of thanks for Dr. Kelli R. Phillips for being a friend and teaching me many valuable experimental techniques. I am appreciative of the support and help I have received in the past month from Dr. Wioletta Scezszel-Fedorowicz. I would also like to thank my labmates William Towns and Jeff Christiansen for their support, help and for all the lively interactions we had in the lab. I express my gratitude for all the help and support I received from a number of graduate students in Biochemistry, Ali, Callie, Sushant, Sanjeev, Jason and Brian at different stages of my graduate life. Finally, last but not the least I am grateful to my husband Aritro Sen for always being there for me, and providing me with all the support I needed during all those days when I was ready to quit. "If I have seen further it is by standing on the shoulders of giants"

Isaac Newton 


\section{Table of Contents}
ABSTRACT
ACKNOWLEDGEMENTS.
III
LIST OF ABBREVIATIONS ..........................................................................

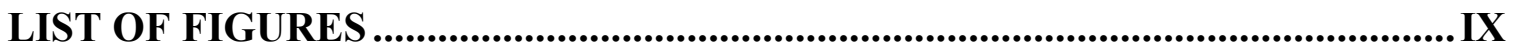
LIST OF TABLES ......................................................................................

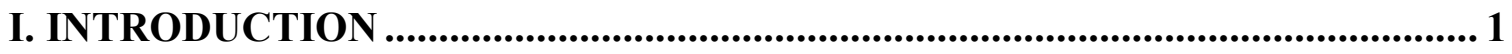

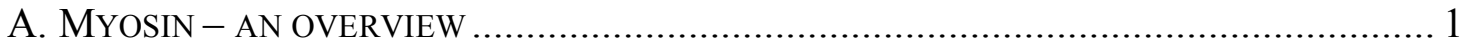
B. MYOSIN FORCE GENERATION ALONG ACTIN ........................................................ 2
C. STRUCTURE AND FUNCTION OF HAIR CELLS ..................................................... 4

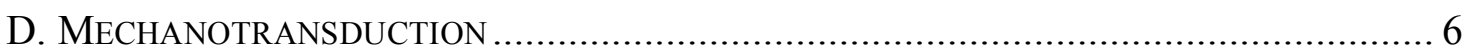
Mechanoelectrical transduction channels........................................................... 8

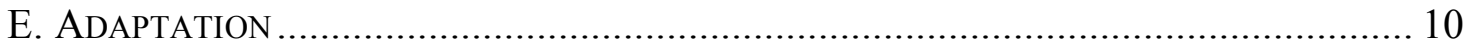
F. IDENTITY OF THE MOLECULAR MOTOR ............................................................ 11

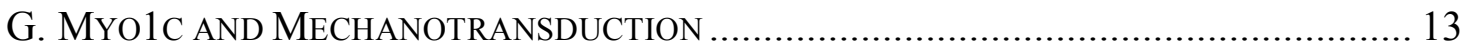
Other proteins of the transduction complex .................................................... 15

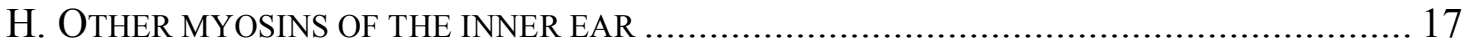

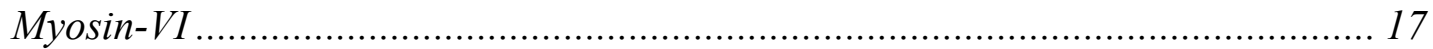

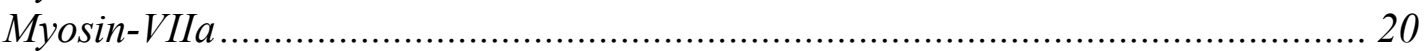

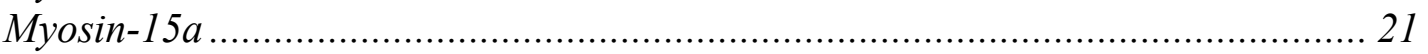

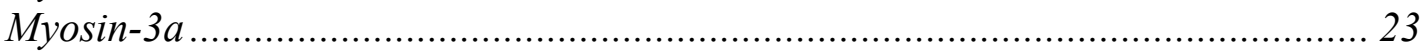

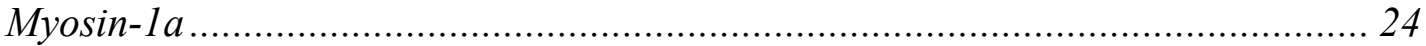

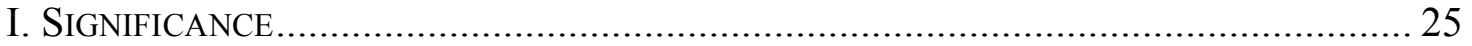

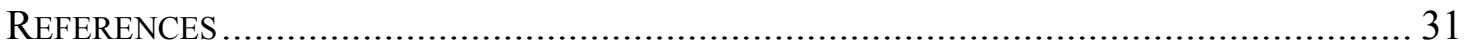

\section{DESIGNING TRUNCATED CONSTRUCTS OF MYOSIN 1C AND}

PURIFICATION OF PROTEINS.................................................................. 42

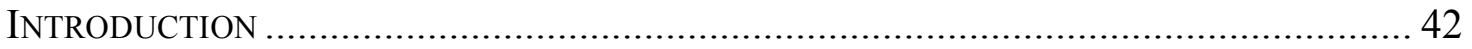

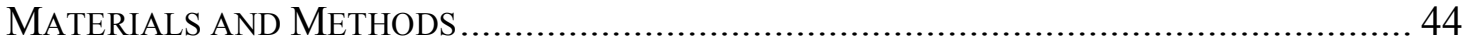

Generation of truncated constructs of Myolc containing the head, tail and each

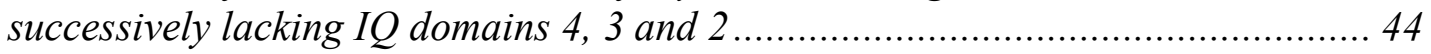

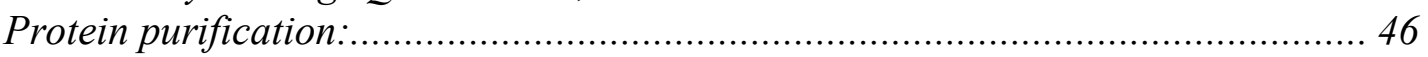

Actin purification from rabbit muscle acetone powder: .................................. 48

Actin cycling of the purified protein to assay the amount of functional Myolc:...... 48

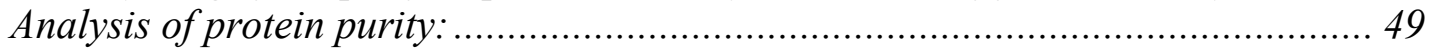

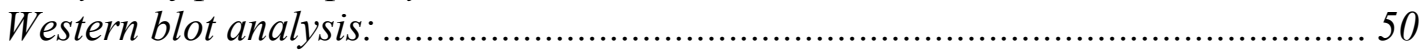

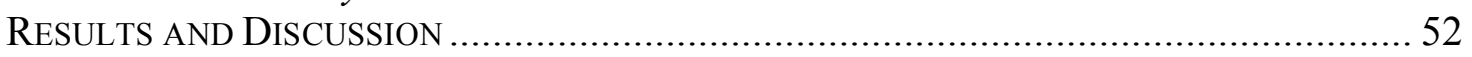

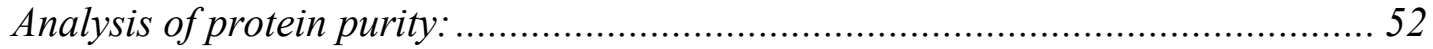

Purification of mutated Myolc constructs: ............................................................ 52

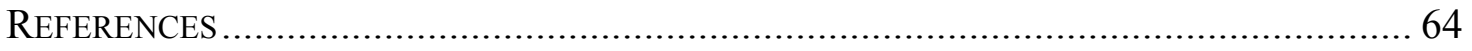

III. DETERMINATION OF ATPASE ACTIVITY OF MYO1C ............................. 66 


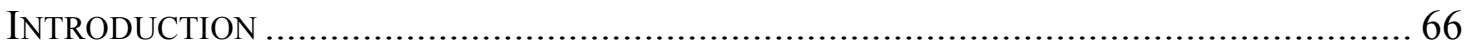

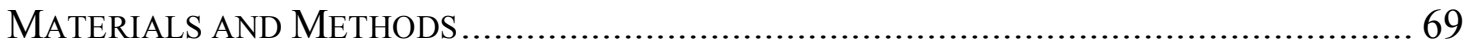

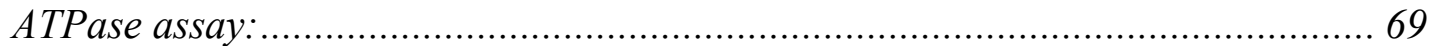

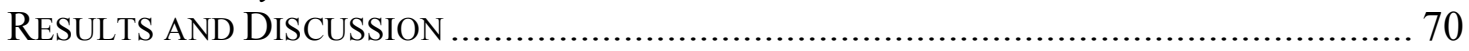

ATPase activity of frog wild type Myolc: ........................................................ 70

ATPase activity of mutant Myolc proteins: ..................................................... 72

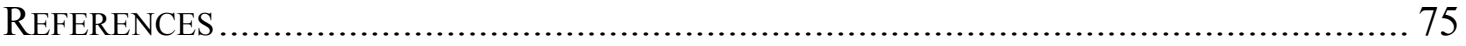

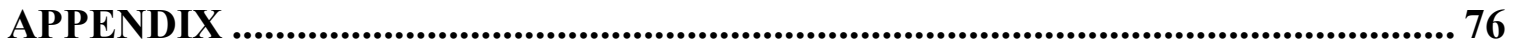

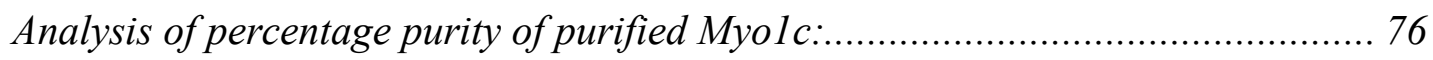

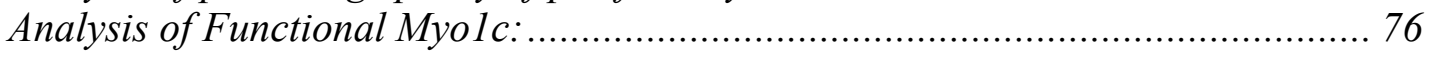




\section{List of Abbreviations}

3THD - Myosin-3 tail homology domain

AA - Alanine/alanine

ADP - Adenosine diphosphate

ATP - Adenosine triphosphate

BAPTA - 1,2-bis $(O$-aminophenoxy)ethane- $N, N, N 9, N 9$-tetraacetic acid

BSA - Bovine serum albumin

C - Cysteine

$\mathrm{Ca}^{2+}-$ Calcium ion

$\mathrm{CaCl}_{2}-$ Calcium chloride

CaM - Calmodulin

Cdh23 - Cadherin 23

DFNA - Deafness autosomal dominant

DFNB - Deafness autosomal recessive

DNA - Deoxyribonucleic acid

EGTA - Ethylene glycol-bis(beta aminoethyl ether)-N,N,N',N'-tetraacetic acid

EnaC - Epithelial sodium channel

F-actin - Filamentous actin

FERM - Band F ezrin-radixin-moesin homology domains

G-actin - Globular actin

HEPES - 4-(2-hydroxyethyl)-1-piperazineethanesulfonic acid

IQ - Isoleucine/ glutamine 


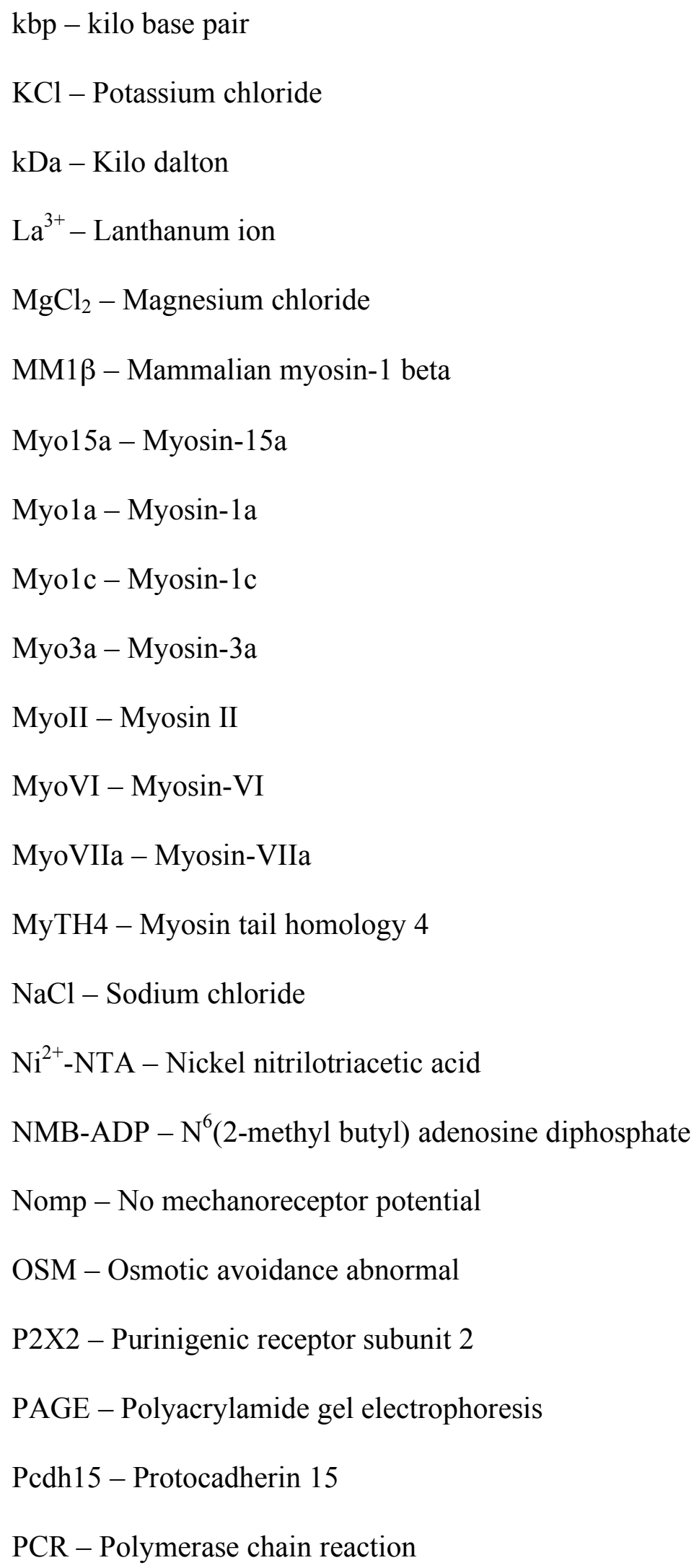


PDZ - Post synaptic density protein 95/ Discs-large protein/ ZO-1 protein

PHR1 - Pleckstrin homology domain retinal protein 1

$\mathrm{P}_{\mathrm{i}}$ - Inorganic phosphate

PMSF - Phenyl methyl sulphonyl fluoride

RG - Arginine/ glycine

RS - Restriction site

SDS - Sodium dodecayl sulphate

SH3 - Src homology domain 3

siRNA - Small inhibitory RNA

$s v$ - Snell's waltzer

Tris - Trishydroxymethylaminomethane

TRP - Transient receptor potential

Y - Tyrosine 


\section{List of Figures}

\section{Introduction}

Figure 1: Myosin force generation along actin.

Figure 2: Differential interference contrast image of an isolated hair cell.............28

Figure 3: Model for hair cell transduction....................................29

Figure 4: Distribution of myosins in the hair cell stereocilia.........................30

\section{II: Designing truncated constructs of Myosin 1c and purification of proteins}

Figure 1: Deletion constructs of Myolc.

Figure 2: Outline of PCR sewing technique.

Figure 3: Sequence of frog wild type Myosin .56

Figure 4: Ethidium bromide stained DNA gels of the truncated construct HIQ12T 60

Figure 5: Purification of frog wild type Myolc. 
Figure 6. Purification of mutated Myolc constructs...............................62

Figure 7. Purification of actin from rabbit muscle acetone powder..................63

\section{Determination of ATPase activity of Myo1c}

Figure 1. Hydrolysis of ATP by Myosin-1c.................................. 74 


\section{List of Tables}

II: Designing truncated constructs of Myosin 1c and purification of proteins

Table 1: Primer sequences for amplification of truncated Myo1c

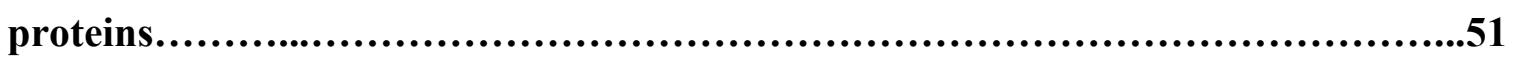

III: Determination of ATPase activity of Myo1c

Table 1: ATPase rates for frog Myo1c with or without $25 \mu M \quad$ Factin....................................................................................73 


\section{Introduction}

\section{A. Myosin - an overview}

Molecular motors have fascinated researchers for decades, with the visualization of vesicle movement (Allen et al., 1982) and then filamentous tracks (Schnapp et al., 1985; Vale et al., 1985b) in the giant axons of squids by differential interference microscopy (Brady et al., 1985). Such movement was observed only in the presence of cell extracts and the nucleotide adenosine trisphosphate (ATP) (Vale et al., 1985). Subsequently these tracks within cells were identified to be microtubules (Schnapp et al., 1985; Vale et al., 1985b) and a novel "protein translocator" was identified and named kinesin (Brady, 1985; Vale et al., 1985a). The existence of actin (Halliburton, 1887) and myosin (Kühne, W, 1859) proteins have been known to researchers for even longer and experiments in the microorganism Nitella demonstrated the movement of myosin proteins along actin tracks in the cells (Sheetz and Spudich, 1983b). This movement also required ATP and could be inhibited by inactivating the myosin head domain (Sheetz and Spudich, 1983a). These exciting observations have led to years of research identifying 18 different classes of eukaryotic myosins to date (for reviews, Thompson and Langford, 2002; Foth et al., 2006).

Myosins are broadly categorized into conventional and unconventional myosins. They are actin-activated motor proteins that use ATP hydrolysis to power their movement along actin tracks (Pollard and Korn, 1973b; for review, Sellers, 2000). The catalytic structure of all myosin classes has been conserved since all the myosins hydrolyze ATP molecules by the same mechanism (for review, Sellers, 2000); however, the domain 
structure differs considerably among different classes of myosins. The conventional myosins have two heavy chains consisting of the two N-terminal head domains, two light chains comprising the neck and an alpha-helical tail domain that is capable of dimerizing and forming filaments (Sellers, 1999). Conventional myosins are found in muscle cells and in the cytoplasm of animal cells and are important in cell division and muscle contraction (for review, Sellers, 2000). The first member of different classes of unconventional myosins was discovered in 1973 as a member of Myo1 family (Pollard and Korn, 1973a). The unconventional myosins, unlike conventional myosins, do not self assemble to form bipolar thick filaments. In general, they contain N-terminal globular head domain, approximately $70-80 \mathrm{kDa}$, followed by the neck region consisting of variable number of IQ domains and a C-terminal cargo-binding tail domain.

\section{B. Myosin force generation along actin}

Myosins bind and hydrolyze ATP and use the energy of hydrolysis to translocate along actin, a process called power stroke (Holmes et al., 2003; Tyska et al., 2002; Fig. 1). As depicted in Fig. 1, the myosin head remains attached to the actin filament after the power stroke from the previous cycle. In the absence of ATP, the system can remain in this state for an indefinitely long period. Binding of ATP to the myosin head results in the release of the head from the actin filament (Fig. 1, state 1). The breakdown of ATP to ADP and inorganic phosphate occurs on the myosin head (Fig 1, state 2). This causes the myosin to move further along the actin filament with the products of hydrolysis attached to the head. The release of the inorganic phosphate causes the myosin to generate the power stroke and move along the actin (Fig. 1, state 3). The myosin thus docks on a new 
site on actin and ADP is released (Fig. 1, state 4). This movement of myosin along actin is tightly regulated by calcium ions $\left(\mathrm{Ca}^{+2}\right)$ and light chain molecules bound to the neck domain (Uyeda et al., 1996; Purcell et al., 2002; Schott et al., 2002; Tanaka et al., 2002; Moore et al., 2004; Lin et al., 2005).

The lever arm theory (for review, Spudich, 1994) hypothesizes that for myosins, small movements of the head are amplified by the neck region that act as lever arms and thus produce a larger displacement of the myosin along actin. This theory has been tested extensively for a variety of conventional and unconventional myosins (Uyeda et al., 1996; Purcell et al., 2002; Schott et al., 2002; Tanaka et al., 2002; Moore et al., 2004; Lin et al., 2005). The lever arm hypothesis has been found to be true for the conventional muscle myosin like myosin-II (MyoII) (Uyeda et al., 1996; Purcell et al., 2002; Schott et al., 2002). There are conflicting data about the unconventional myosin, Myosin V. Several groups have demonstrated the importance of the neck length in myosin movement (Purcell et al., 2002; Schott et al., 2002; Moore et al., 2004; Sakamoto et al., 2005). In contrast, one group has shown that the neck length is not important in myosin movement (Tanaka et al., 2002).

The inner ear is notable for its repertoire of myosin proteins, both conventional and unconventional. Mutations in a number of these myosin molecules have been found to cause auditory and vestibular defects in mice and humans (Avraham et al., 1995; Mburu et al., 1997; Weil et al., 1997;Wang et al., 1998; Melchionda et al., 2001; Walsh et 
al., 2002; D'Adamo et al., 2003). In the following sections, the hair cell structure and function will be discussed in brief, followed by the role of myosins in these processes.

\section{Structure and function of hair cells}

The auditory and vestibular systems owe their sensitivity to hearing and balance respectively to hair cells (Fig. 2), the epithelial receptors found in the inner ear (for review, Hudspeth, 1989b). Hair cells are sensory cells that respond to acoustic vibrations and head movements and couple mechanical stimuli to electrical signals that are ultimately sent to the brain via the nervous system (for review, Hudspeth, 1989b). The most important characteristic feature of hair cells is the hair bundle, the mechanoreceptive structure that projects outwards from the apical surface of the hair cells. The hair bundle is composed of 20-300 stereocilia, each consisting of an actin cytoskeletal core that is extensively cross-linked. Each stereocilium is made up of parallel actin bundles that confer rigidity to the hair bundle. The actin bundles are highly crosslinked by actin bundling proteins like fimbrin (for review, Tilney et al., 1992) and espin (Zheng et al., 2000) and surrounded by a plasma membrane. Like in other cell types, the actin core in hair cells is polarized, with its barbed end, also called the $(+)$ end oriented towards the tip of the stereocilia and the pointed end or the (-) end directed towards the base of the stereocilia (for review, Tilney et al., 1992). Stereocilia are arranged in rows of increasing height giving the hair bundle a staircase-like appearance (Fig. 2). In the auditory organ, the cochlea, hair bundle height also varies allowing it to detect sounds of different frequencies (Holton and Hudspeth, 1983; for review, Tilney et al., 1992). Each stereocilium tapers towards its base where the number of actin filaments 
is reduced and inserts into a dense network of actin filaments called the cuticular plate. A single true cilium called the kinocilium is present at the tall extreme of the bundle (Hudspeth, 1989a) and specifies the orientation of the hair bundle (for review, Tilney et al., 1992). The kinocilium degenerates in the adult cochlea (Hudspeth and Jacobs, 1979) and is thought to be required during development of the hair bundle (Kelley et al., 1992).

Within the hair bundle each stereocilium is connected to its next tallest neighbor by very fine extracellular strands called the tip links (Pickles et al., 1984; Kachar et al., 2000), that have been implicated to play an important role in hair cell transduction (Holton and Hudspeth, 1986; Howard and Hudspeth, 1988; Zhao et al., 1996; Marquis and Hudspeth, 1997). The tip links are broken in the presence of the calcium chelators 1,2-bis( $O$-aminophenoxy)ethane- $N, N, N 9, N 9$-tetraacetic acid (BAPTA) or ethylene glycol-bis(beta aminoethyl ether)-N,N,N',N'-tetraacetic acid (EGTA; Assad et al., 1991; Zhao et al., 1996; Marquis and Hudspeth, 1997) and the cation lanthanum $\left(\mathrm{La}^{3+}\right.$; Kachar et al., 2000; Goodyear and Richardson, 2003). They are however resistant to the protease subtilisin (Goodyear and Richardson, 2003). Electron microscopic studies revealed that the tip link is a right-handed coiled-coil double filament that usually forks into two branches at the point of contact with the taller stereocilium (Kachar et al., 2000). In a recent finding, it has been suggested that the two structural proteins, cadherin 23 (Cdh23) and protochadherin 15 (Pcdh15), interact to form tip links in adult hair cells of guinea pigs (Kazmierczak et al., 2007). These two proteins are predicted to be structurally suitable to bridge the nearly $150 \mathrm{~nm}$ gap at the tips of the stereocilia (Kazmierczak et al., 2007). 


\section{Mechanotransduction}

Mechanosensory transduction is the process that converts mechanical stimuli to signals that are conveyed to the brain (Hudspeth and Jacobs, 1979). This is achieved by opening channels in the membrane of the transducing cells and increasing ion influx into cells, causing the cells to depolarize and initiate neural signaling (for review, Holt and Corey, 2000). Hair bundles respond to mechanical force by pivoting at their bases but do not bend along their lengths (Hudspeth, 1989a; for review, Hudspeth, 1997). This is due to the rigid structure of the stereocilium and the change in dimension at the base where it inserts into the cuticular plate (Hudspeth, 1989a, for review, Hudspeth, 1997). The displacement of the hair bundle (Fig. 3) can either be positive or negative, termed as excitatory and inhibitory stimuli respectively (for review, Hudspeth, 1989b). Positive displacements move the bundle towards its taller edge and open transduction channels (Hudspeth, 1985, 1989a, 1992; for review, Colclasure and Holt, 2003) and depolarize the cell. In contrast, negative displacements cause the bundles to move towards the shorter edge thereby hyperpolarizing the cells by closing the transduction channels (Hudspeth, 1985, 1989a, 1992; for review, Colclasure and Holt, 2003). Displacements at right angles to the bundle's axis of symmetry however do not produce any change in the resting potential of the cell (Hudspeth, 1985, 1989a, 1992). In a resting hair cell approximately $15 \%$ of the transduction channels remain open and the resting potential of the cell is about $-60 \mathrm{mV}$ (Hudspeth, 1989a). Therefore there is a resultant inward flow of current even in the absence of any stimulus. 
The time of response of hair cells to mechanical stimuli is approximately 100-500 microseconds (Hudspeth, 1989b, 1997). The hair cells respond very quickly to bundle displacement suggesting a direct model of hair cell transduction rather than the involvement of conventional signaling pathways using secondary messengers (Hudspeth, 1989a). As well, it has been demonstrated that the ion channel's gate swings 2-4 nm (Hudspeth et al., 2000) when it is open following bundle displacement. This led to the gating spring model of transduction (Corey and Hudspeth, 1983; Howard et al., 1988; Markin et al., 1995; for review, Eatock et al., 2000). According to this model, elastic gating springs transmit the mechanical force from the displacement to transduction channels located at the tips of the stereocilia and increase the open probability of the channels (Corey and Hudspeth, 1983). Thus the probability of the channel being open depends on the tension in these springs. When tension in the gating spring is high, channels remain open most of the time, while when tension is low, most of the channels close. The gating spring had been long assumed to be the tip link (for review, Hudspeth, 1989b; Assad et al., 1991; Pickles et al., 1991). However, the apparent rigidity of the tip link as determined by electron-microscopic examination of its structure, makes it unlikely to be the entire gating spring (for review, Hudspeth, 1997; Kachar et al., 2000; Howard and Bechstedt, 2004; Tsuprun et al., 2004). Instead the elastic element is thought to be lying in series with the tip link (Kachar et al., 2000; Howard and Bechstedt, 2004; Tsuprun et al., 2004). 


\section{Mechanoelectrical transduction channels}

Transduction channels are non-selective cation pores that permit the entry of potassium ions that are present in highest concentration in the endolymph bathing the hair bundles (for review, Gillespie and Walker, 2001). The channels are also permeable to divalent calcium ions (Corey and Hudspeth, 1979; for review, Corey, 2006; for review, Ricci et al., 2006) and the concentration of the latter increases during mechanotransduction (Denk et al., 1995; Lumpkin et al., 1997; Ricci and Fettiplace, 1997). The channels also allow the passage of amino glycoside antibiotics (Kroese et al., 1989) that can obstruct the channels and thus damage the hair cells leading to impaired hearing (Imamura and Adams, 2003; Kawamoto et al., 2004). As well, the channels can be blocked with amiloride derivatives, calcium channel antagonists like D-600 and nifedipine (Engel et al., 2002). However, this inhibition profile is inconsistent with any of the known contenders for the transduction channel protein discussed below.

Initial speculations that the transduction channel may consist of the alpha subunit of the epithelial sodium channels (EnaC) were discarded when mice lacking the alpha subunit demonstrated normal hair cell transduction (Rusch and Hummler, 1999). The purinigenic receptor $\mathrm{P} 2 \mathrm{X} 2$ present in hair bundles was another attractive candidate, however its expression is delayed with respect to the onset of transduction (Glowatzki, 1997). The transient receptor protein superfamily or TRP family appears to be quite suitable for this process and it also includes two known channels involved in mechanotransduction, no mechanoreceptor potential (NompC) in flies (Walker et al., 2000) and osmotic avoidance abnormal (OSM-9) in worms (Harteneck et al., 2000). The 
loss of function of nompC gene in Drosophila melanogaster results in the loss of sensory transduction (Walker et al., 2000; Kim et al., 2003; Gong et al., 2004). The zebrafish counterpart of nompC also encodes a TRP channel, important in mechanotransduction (Sidi et al., 2003). The kinocilium of Xenopus laevis expresses the $\mathrm{Ca}^{+2}$ sensitive channel protein TRPN1, a homolog of nompC and has been suggested to be involved in mechanotransduction (Shin et al., 2005). However, TRPN1 or other homologs of nompC are not present in mammals (Sidi et al., 2003; Shin et al., 2005).

TRP channels exhibit biophysical and pharmacological properties that are similar to those of transduction channels in hair cells (Strassmaier and Gillespie, 2002). The most interesting candidate examined thus far is TRPA1. The expression profile of this gene corelates well with the onset of mechanotransduction in mammals (Corey et al., 2004) and decrease of TRPA1 expression in the mouse vestibular hair cells by siRNA also impaired mechanotransduction (Corey et al., 2004). However, TRPA1 knockout mice have normal auditory function (Kwan et al., 2006; Bautista et al., 2006). Among other attractive candidates are TRPV4 (Liedtke et al., 2000; Takumida et al., 2005; for review, Cuajungco et al., 2007) and TRPML3 (Di Palma et al., 2002), both linked to hearing loss in mammals (for review, Cuajungco et al., 2007). However, their candidacies are still questionable (for review, Cuajungco et al., 2007) and the search for the transduction channel continues (for review, Corey, 2006). 


\section{E. Adaptation}

During mechanical stimulation, the hair bundle is deflected and the transduction channels open permitting an influx of cations into the bundle (for review, Eatock, 2000). The transduction channels are extremely sensitive to bundle displacements and following sustained deflection, the hair bundle adapts for the detection of the next stimulus (Holt et al., 1997). Adaptation is an extremely important process in hair cells that resets the sensitivity of the transduction channels to prolonged stimuli. Adaptation is distinguished from desensitization by the fact that following adaptation, a transduction channel can be fully opened if the mechanical force is large enough (for review, Eatock, 2000). Adaptation can be slow or fast and each modifies the mechanical properties of the hair bundle.

Fast adaptation is remarkably quick (1-2 ms) in lower vertebrates and involves active hair bundle movements (Ricci et al., 2000; Ricci, 2003). Fast adaptation is thought to involve calcium binding directly at or near the channel that alters the relation between tension in the gating springs and open probability of the channel (Wu et al., 1999). It is thought that calcium binds to intracellular sites on the channel and causes the channel to shut (Ricci and Fettiplace, 1997). As calcium concentration in the cell decreases, the channels return to their original resting state (for review, Holt and Corey, 2000).

Slow adaptation takes place over tens of milliseconds and is thought to be mediated by an adaptation motor (Howard and Hudspeth, 1987; Assad and Corey, 1992; for review, Holt and Corey, 2000). The motors are thought to attach the actin core of the 
stereocilium to the transduction channel, climbing along the stereocilium to adjust the tension in the gating springs (for review, Holt and Corey, 2000). In response to a positive bundle displacement, tension in the spring increases, opening cation selective channels in the bundle and the motor slips down along the actin core thus decreasing the tension and the channels close (Gillespie and Cyr, 2004). As a result, the bundle can be deflected further by a second stimulus, thus allowing for increased sensitivity following protracted hair bundle deflection. The adaptation motor may also play a role in assembling and properly positioning the transduction apparatus in the hair cells (Zhao et al., 1996).

\section{F. Identity of the molecular motor}

The adaptation motor actively generates force and physically interacts with the actin filaments in the stereocilia. These observations indicated that a myosin might be the appropriate candidate for the motor. Also the motor activity requires the presence of $\mathrm{Ca}^{+2}$ and CaM (Walker and Hudspeth, 1996; Lumpkin and Hudspeth, 1999) both of which control the activity of unconventional myosins (Wolenski, 1995; Bahler and Rhoads, 2002). Furthermore, the use of ADP analogs and myosin inhibitors have been found to block slow adaptation (Gillespie and Hudspeth, 1993). Using photochemical crosslinking experiments, an unconventional myosin, myosin-1c (Myo1c), belonging to the myosin I family was identified in hair bundles in 1993 (Gillespie et al., 1993). The head domain of Myo1c binds ATP and actin and produces force for the movement along actin (for review, Mooseker and Cheney, 1995b). Next to the head lies the alpha helical neck region consisting of four isoleucine and glutamine containing IQ domains with the

consensus sequence being $<\mathrm{IQX}_{3} \mathrm{RGX}_{3} \mathrm{R}>$ (Rhoads and Friedberg, 1997). These IQ 
domains can bind $\mathrm{CaM}$ and act as regulatory switches for myosin activity. The Cterminal domain is the most variable of all domains (Mooseker and Cheney, 1995a) and for Myo1c, it has been demonstrated to bind membrane and phospholipid (Reizes et al., 1994), specifically phosphoinosotide 4,5 bisphosphate (Hokanson and Ostap, 2006). Immunolocalization studies of hair bundles revealed the presence of Myolc near the stereociliary tips, in the pericuticular necklace and in the hair cell body (Gillespie et al., 1993, Hasson, 1997; Steyger et al., 1998; Garcia et al., 1998; Metcalf, 1998) and is absent from a distinct cap-like zone at the tips of the stereocilia (Schneider et al., 2006). In 1994, Metcalf et al., isolated a cDNA encoding myosin protein from the brain and sacculus of bullfrogs that resulted in the identification of a $119 \mathrm{kDa}$ protein with high sequence homology to the adrenal mammalian myosin1 beta (MM1 $\beta$ ). Thus the unconventional myosin, Myo1c (previously called Myolbeta) present in the tips of stereocilia where transduction takes place (Steyger et al., 1998; Garcia et al., 1998; Metcalf, 1998) has become the most well-supported candidate for the adaptation motor protein (Gillespie et al., 1993; Hasson et al., 1997; Holt et al., 2002).

In an experimental approach to examine the role of Myolc in adaptation, a mutant Myo1c was designed (Holt et al., 2002) with increased affinity of binding to an ADP analog (Gillespie et al., 1999). The mutant Myolc has a key tyrosine residue replaced by glycine in its ATP binding groove (Gillespie et al., 1999), making it sensitive to nonhydrolyzable ATP-analogs like $\mathrm{N}^{6}$ (2-methyl butyl) adenosine diphosphate (NMB-ADP) that maintains the Myolc in rigid conformation and inhibits its motor activity and thus inhibits adaptation. However, in the presence of ATP, the mutant Myo1c behaves similar 
to the wild-type protein (Gillespie et al., 1999). Thus the transgenic mice bearing this mutation allowed for targeted disruption of Myolc function when NMB-ADP was introduced into vestibular hair cells concomitant with mechanical stimulation of the hair bundle (Holt et al., 2002). The transgenic mice bearing the mutant Myolc had normal transduction and adaptation in the presence of ATP (Holt et al., 2002). However, when the ADP analog was introduced into the hair cells, adaptation was completely blocked (Holt et al., 2002). It is thought that in the presence of NMB-ADP, the mutant Myo1c molecules are unable to translocate along actin and freeze in their tracks thus abolishing adaptation (Holt et al., 2002; Stauffer et al., 2005). In addition, another finding implicates Myo1c in fast adaptation as well (Stauffer et al., 2005). The researchers show that the rate of fast adaptation is dependent on Myolc and that fast adaptation is also blocked in mutant Myo1c knock-in mice. Myo1c is suitably positioned near the transduction channels and it is hypothesized that following transduction, rapid conformational change of Myo1c causes calcium to bind directly to the Myolc-CaM complex and causes the channels to close (Stauffer et al., 2005; Manceva et al., 2007).

\section{G. Myo1c and Mechanotransduction}

In the proposed model of transduction, mechanical force increases tension in the gating spring, causing the transduction channels to open, permitting influx of cations including $\mathrm{Ca}^{2+}$ into the hair bundle (Corey and Hudspeth, 1979; for reviews, Corey, 2006;

Ricci et al., 2006). Accumulation of calcium and its interaction with $\mathrm{CaM}$ in the stereociliary cytoplasm is expected to deplete CaM from Myolc binding sites. The gating spring can thus pull down the myosin molecules alleviating the tension in the spring and 
it shortens. When the spring reaches its resting tension, the channel returns to its resting state with a decrease in intracellular calcium (reviewed in Gillespie and Cyr, 2004). This restores motility and the balance between the upward force produced by Myolc and downward tension in the springs (for review, Gillespie and Corey, 1997).

Myo1c binds to its 'receptors' that are specific intracellular binding sites for Myo1c located near the stereociliary tips and other subcellular locations (Cyr et al., 2002). This interaction is thought to be vital for the process of transduction and is regulated by calcium and CaM (Cyr et al., 2002). It is believed that the receptors are not endogenous CaM or self-aggregated Myolc molecules (Cyr et al., 2002). As well, it was concluded that the receptors were not membrane phospholipids (Phillips et al., 2006), although Myo1c has been shown to bind phosphoinosotide 4,5 bisphosphate (Hirono et al., 2004; Hokanson and Ostap, 2006). The Myolc receptors are thought to couple Myolc to the rest of the transduction apparatus. It has been shown that Myolc binds to its intracellular receptors through the IQ domains in its neck region (Cyr et al., 2002). This suggests that the interaction of Myo1c with the transduction complex is regulated by CaM. As well, CaM-free IQ2 domain of Myolc can bind intracellular receptors (Cyr et al., 2002; Phillips et al., 2006) and it is thought that CaM bound IQ3 may enhance the above interaction (Phillips et al., 2006).

Removal of CaM from the hair bundle halted the movement of the adaptation motor and thereby abolished adaptation (Walker and Hudspeth, 1996). However, CaM also binds to plasma membrane calcium ATPase in hair cells and depletion of CaM could have also depleted the calcium pump, abolishing adaptation. Also CaM binding calcium 
may control adaptation by speeding up the release of ADP from Myolc. This has important implications during mechanotransduction. The enhanced calcium concentration during transduction leads to dissociation of CaM but permits Myolc to go through its ATPase cycle with reduced force production by the motor. This in turn helps Myolc to perform its role in adaptation better by exerting less force on the transduction channel (for review, Gillespie and Cyr, 2004).

\section{Other proteins of the transduction complex}

Years of research focused on identifying the proteins other than Myolc in the assembled transduction complex has led to the identification of $\operatorname{Cdh} 23$ and $\operatorname{Pcdh} 15$ as components of the tip link (Siemens et al., 2004; Sollner et al., 2004; Kazmierczak et al., 2007). Of these, one potential candidate for the Myo1c receptor is the protein Cdh23 (Phillips et al., 2006). It has been shown that Myo1c interacts with Cdh23 in heterologous expression systems (Siemens et al., 2004), although such interactions have not yet been observed in hair cells. Cdh23 is mutated in humans with Usher syndrome type 1D (USH1D) that leads to both deafness and blindness and also to age-related hearing loss (Bolz et al., 2001; Bork et al., 2001; Di Palma et al., 2001; Noben-Trauth et al., 2003). Studies in the waltzer mouse with mutations in $\mathrm{Cdh} 23$ showed developmental defects in the stereociliary organization and implicated $\mathrm{Cdh} 23$ in hair cell differentiation (Di Palma et al., 2001). However its abundance in hair cells of adult animals was very low, persisting only near the kinocilial links in the vestibular organs (Lagziel et al., 2005; Michel et al., 2005) as compared to younger ones, suggesting its importance in development (Boeda et al., 2002). Siemens et al. (2003) have suggested that Cdh23 is a 
component of the tip link in adult animals. They have shown the persistence of Cdh23 in the stereocilia of older animals at the stereociliary tips where transduction actually occurs. The zebrafish mutant sputnik that has a mutation in the gene encoding Cdh23 (Sollner et al., 2004), associated with loss of tip links in these animals. Myolc receptor interaction is absent in hair cells of Cdh23 mutant mice (Phillips et al., 2006), suggesting that these proteins interact either directly or in the presence of a third molecule that is missing in Cdh23 mutant mice (Phillips et al., 2006).

Pcdh 15 was identified in the context of the human disorder Usher 1F (Ahmed et al., 2001) and the protein was found to be present in the stereocilia of the cochlea and the vestibule (Ahmed et al., 2003). The Ames waltzer mice deficient in protocadherin 15 were found to have defects in the polarity of the hair bundle (Senften et al., 2006) and degeneration of the stereocilia, suggesting a role for Pcdh 15 in development and maintenance of the hair bundles (Alagramam et al., 2001). In addition, these mice were also found to be defective in mechanotransduction thus explaining their deafness and circling phenotype (Senften et al., 2006). As well, the tip link antigen (TLA) present in the tip link and the kinocilial links of hair bundles (Goodyear and Richardson, 2003) has been identified by mass spectrometry to be Pcdh15 (Ahmed et al., 2006). Although Pcdh15 and Cdh23 have been shown to interact in vitro (Kazmierczak et al., 2007), further studies are necessary to put the missing pieces of the transduction complex puzzle together. 
Another hair cell protein pleckstrin homology domain retinal protein 1 (PHR1) has been shown to interact with Myolc (Etournay et al., 2005), however the fact that it interacts with IQ4-tail region of the protein excludes it from being the receptor (Phillips et al., 2006). In addition, PHR1 knockout mice do not demonstrate any sensory defects (Xu et al, 2004).

The model for Myolc regulation suggests that an increase in calcium concentration near the stereociliary tips causes the CaM bound to Myolc to dissociate and enables the interaction of Myolc with its receptors, thus facilitating adaptation (for review, Gillespie and Cyr, 2004). The paucity of the hair cells in the inner ear, however, makes it extremely difficult for molecular identification of the receptors.

\section{H. Other myosins of the inner ear}

\section{Myosin-VI}

Myosin-VI (MyoVI) (Fig. 4) is an unconventional myosin first identified in Drosophila and demonstrated to play an important role in embryogenesis (Kellerman and Miller, 1992). It is also expressed in adult flies and shown to be required during fly spermatogenesis (Rogat and Miller, 2002). MyoVI was first identified in mammals in the porcine kidney cell line LLC-PK1 (Hasson and Mooseker, 1994). Like its Drosophila homolog, this mammalian enzyme has a N-terminal head domain consisting of ATP and actin binding motifs, a 50 amino acid linker domain that is unique to MyoVI immediately following the head, a neck domain consisting of one IQ consensus region for binding $\mathrm{CaM}$ and a tail domain consisting of coiled-coil regions that is predicted to form 
homodimers (Hasson and Mooseker, 1994). MyoVI is different from other classes of unconventional myosins in that it moves along actin towards the pointed ends instead of barbed ends (Wells et al., 1999). It has been recently shown that the insert at the end of the motor domain binds to $\mathrm{Ca}^{+2}-\mathrm{CaM}$ (Bahloul et al., 2004) and determines the reversality of movement of MyoVI on actin (Park et al., 2007). This feature allows MyoVI to move cellular cargo from the surface of the cell to the inside, towards the pointed end of the actin filaments. MyoVI has also been demonstrated to be a processive motor that is bound to actin for longer intervals during the actin-crossbridge formation (Rock et al., 2001). This enables the protein to carry its load further along actin with fewer dissociations and reassociations.

Subsequent characterization of the Snell's waltzer (sv) mice, that exhibit profound deafness and circling behaviour, revealed that the mutation mapped to a region of the chromosome coding for MyoVI. The mutation deleted a $130 \mathrm{bp}$ region of the gene inducing a shift in the reading frame and a premature stop codon after the neck domain (Avraham et al., 1995). Hair cell degeneration in the $s v$ mice is visible at three weeks of age and Myo VI immunoreactivity was absent from cytoplasm and the cuticular plate of the inner and outer hair cells of the cochlea in the mutant mice compared to wild type (Avraham et al., 1995). In a later study by Self et al., (1999), it was found that the $s v$ mice had gross abnormalities of the stereocilia by postnatal day 7 , revealing fused stereocilia also called giant stereocilia. As reported years earlier (Deol and Green, 1966), the organ of Corti develops normally in the $s v$ mice up to postnatal day 12 followed by a progressive loss of hair cells (Avraham et al., 1995). The apparent discrepancy in the 
ages could be because of the use of light microscopy (Deol and Green, 1966; Avraham et al., 1995) compared to electron microscopy by Self et al. However, both studies reported that the $s v$ mice had gross stereociliary defects by postnatal day 20), indicating that MyoVI may play a role in maintaining the hair cells in these animals and not in their development. Because MyoVI is found at the base of the hair cells in the cuticular plate, it is speculated to be important in the transport of cellular components and anchoring the stereocilia in the dense actin network (Self et al., 1999). It has been shown that MyoVI is associated with the terminal web in brush border epithelia (Hasson and Mooseker, 1994), a polarized cell and thus thought to play a role in endocytosis. MyoVI has also been shown to associate with uncoated vesicles in clathrin-dependent endocytosis in polarized cells (Aschenbrenner et al., 2004). Thus the distribution and role of MyoVI are quite similar across different cell types.

Mutation in human MYOVI was first identified in an Italian family with an early onset of progressive loss of hearing but normal vestibular functions (Melchionda et al., 2001). By the age of 50, all adults in the family with the mutation in MYOVI were found to be suffering from profound deafness (Melchionda et al., 2001). The mutation (C442Y) results in the replacement of a crucial cysteine $(\mathrm{C})$ residue by tyrosine $(\mathrm{Y})$ in the motor domain of MyoVI that is thought to destabilize the protein and result in its degradation. In addition the zebrafish mutant satellite has been shown to carry mutations in myo6b, that results in defective stereocilia and decreased endocytosis (Seiler et al., 2004). Another zebrafish mutant ru920 lacking important structural motifs of MyoVI has also been shown to be defective in mechanotransduction (Kappler et al., 2004). 


\section{Myosin-VIIa}

Mutations in the motor domain of Myosin-VIIa (MyoVIIa) (Fig. 4) have been linked to the shaker phenotype in mice (Mburu et al., 1997) characterized by cochlear and vestibular defects as also in humans with Usher (USH) 1B syndrome (Weil et al., 1995) or non-syndromic deafness disorders DFNB2 (Weil et al., 1997) and DFNB11 (Friedman et al., 1999). Myo VIIa is an unconventional myosin consisting of an N-terminal head domain that can bind actin and ATP (Sellers, 2000). It is an actin plus-end directed motor protein (Udovichenko et al., 2002; Inoue and Ikebe, 2003). The head is followed by five IQ domains predicted to bind CaM (Udovichenko et al., 2002; Inoue and Ikebe, 2003) followed by a very long tail region consisting of several protein-protein interaction domains consisting of FERM, MyTH4 and SH3 domains (Sellers, 2000).

Several binding partners of the MyoVII tail have been identified over the years, a significant number of which were identified in the context of the Usher (USH) syndrome in humans, a genetic abnormality characterized by deafness and later onset of blindness associated with retinitis pigmentosa. These include the scaffold protein harmonin (Boeda et al., 2002), SANS (Adato et al., 2005), vezatin (Kussel-Andermann et al., 2000) and the recently identified tight junction protein shroom-2 (Etournay et al., 2007). Myo VIIa also binds to the structural protein protocadherin 15 to maintain cohesion among the bases of the stereocilia (Senften et al., 2006). It is suggested that MyoVIIa by virtue of its protein cross-linking ability plays a very important role in the stereociliary development and organization (Adato et al., 2005; Etournay et al., 2007). 
In addition to MyoVIIa's role in stabilizing the hair bundle, it has also been suggested that it plays an important role in mechanotransduction in the cochlea (Kros et al., 2002). The MyoVIIa mutant mouse shaker 1 have seven different mutations, out of which five have been mapped to the motor domain, thus potentially interrupting its motor properties. These mice had a very high bundle deflection threshold of about $150 \mathrm{~nm}$ and had abnormal transduction currents (Kros et al., 2002). As well, the hair bundles in these animals were grossly disorganized (Kros et al., 2002). The authors hypothesized that MyoVIIa, by virtue of its distribution in the stereocilia and its interactions with the scaffold proteins, would be an ideal candidate to maintain tension in the transduction channels at the tips of the stereocilia (Kros et al., 2002).

\section{Myosin-15a}

Myosin-15a (Myo15a) is an unconventional myosin localized to the tips of stereocilia (Fig. 4; Belyantseva et al., 2005). Like all other myosins of this class, Myo15a has a N-terminal motor domain containing ATP and actin-binding motifs, followed by two IQ domains predicted to bind $\mathrm{CaM}$ and a C-terminal tail containing potential proteininteracting domains like myosin tail homology 4 domain, (MyTH4), band F ezrinradixin-moesin homology domains (FERM), src-homology domain 3 (SH3) and post synaptic density protein 95/ Discs-large protein/ ZO-1 protein (PDZ) domains. Preceding the motor domain is a long stretch of proline-rich amino acids of unknown function (Anderson et al., 2000). As well, Myo15a is the only unconventional myosin known to contain a PDZ domain in its C-terminal (Belyantseva et al., 2005). Myo15a is an actin 
plus-end directed motor protein demonstrated to move cellular cargo to the tips of filopodia (Belyantseva et al., 2005).

Myo15a is thought to contribute to the maintenance of the staircase pattern of the stereocilia by transporting another PDZ domain-containing protein whirlin to the tips (Belyantseva et al., 2005). Whirlin has been demonstrated to be responsible for maintenance of hair bundle structure (Mburu et al., 2003). The graded and dynamic expression of whirlin at the tips of stereocilia is thought to be part of a molecular mechanism required to terminate actin polymerization at the tips (Kikkawa et al., 2005).

Mutations in Myo15a cause the non-syndromic deafness disorder DFNB3 in human patients (Wang et al., 1998) and gross cochlear and vestibular defects in the mouse mutant shaker 2 (Liang et al., 1999). The inner ear of shaker 2 mice revealed very short stereocilia and the appearance of abnormal actin-rich processes called cytocauds (Anderson et al., 2000). Shaker 2 mice have similar phenotype as whirler mice lacking the protein whirlin. Immunofluorescence studies of homozygous whirler mice revealed disorganized hair bundles and absence of whirlin, but Myo15a immunoreactivity was still present in these animals (Belyantseva et al., 2005). As well, heterologous expression and localization of GFP-myo15a and DsRed-whirlin in Cos7 cells demonstrated colocalization of the two proteins at the filopodia, whereas expression of a mutant Myo15a containing a mutation in the motor domain, failed to transport either proteins to the tips of the filopodia, indicating a role for Myo15a in the translocation of whirlin (Belyantseva et al., 2005). Despite abnormal architechture of the hair bundles in these mutants, 
mechanotransduction and adaptation are unaffected in young whirlin mutant mice as well as shaker 2 mutants before the onset of degeneration of the stereocilia (Stepanyan et al., 2006). Thus the principal role of this motor protein seems to be the transport of crucial cellular cargo and also in maintaining the structural integrity of the stereocilia at the tips where mechanotransduction occurs (Belyantseva et al., 2005).

\section{Myosin-3a}

Myosin-3a (Myo3a) is an unconventional myosin (Fig. 4), first identified in Drosophila and shown to play a role in photoreceptor structure and function (Porter and Montell, 1993). Analysis of the structure of the vertebrate Myo3a revealed the presence of a motor domain and a neck domain containing two IQ motifs and a third IQ motif in the tail domain, also predicted to contain two Myo3 tail homology domains, 3THDI and 3THDII (Dose and Burnside, 2000). Preceding the motor domain, lies an N-terminal kinase domain that undergoes autophosphorylation (Ng et al., 1996). Human Myo3a has been demonstrated to be an actin-activated molecular motor that moves toward the barbed-end of actin filaments (Komaba et al., 2003).

Mutation in the motor domain of human Myo3a has been linked to nonsyndromic hearing disorder DFNB30 characterized by late-onset of deafness, but balance and vision are unaffected in these individuals (Walsh et al., 2002). Subsequent immunolocalization studies of Myo3a in rats demonstrated that it is expressed around the stereociliary tips in a "thimble-like" pattern (Schneider et al., 2006) and is predicted to be involved in protein 
translocation to the tips, perhaps facilitating the assembly of the mechanotransduction apparatus, or in maintaining stereociliary tension (Schneider et al., 2006).

\section{Myosin-1a}

Myosin-1a (Myo1a) was identified as a $110 \mathrm{kDa}$ protein in the brush border of the renal microvilli (Coluccio, 1991) and also in the brush borders of the intestinal epithelial cells (Mooseker, 1985). Like other class I myosins, it has a N-terminal motor domain, three IQ-motif containing consensus regions and an acidic tail domain (Mooseker and Cheney, 1995a). It has been demonstrated to maintain the highly ordered actin-rich brush borders on the apical surface of intestinal enterocytes (Tyska and Mooseker, 2002). Subsequent development of Myola knockout mice did not reveal any overt phenotypes in the intestinal brush-border cells, although some fusions of the microvilli in the enterocytes and disorganization of the brush border structures were observed (Tyska et al., 2005). The most striking observation of this study was the up-regulation of Myo1c in the brush border, suggesting that the lack of phenotype in the knockout could be due to compensation of Myola function by Myo1c (Tyska et al., 2005).

In a recent study, non-syndromic deafness DFNA48 was mapped to the chromosome locus coding for Myola (D'Adamo et al., 2003). Eight different mutations of Myola were identified, of which six were predicted to be responsible for hearing loss in these patients (Donaudy et al., 2003). Expression of Myola in the cochlea was confirmed by reverse transcriptase PCR analysis from mouse cochlear tissue (Donaudy et al., 2003). However, Myola protein expression and localization in the inner ear is 
unknown and the Myola knockout mice have no apparent auditory or vestibular defects, although detailed examinations of inner ear defects have not been performed thus far. In another study researchers created a recombinant Myola with mutation in a key aspartate residue (Yengo et al., 2007) in the active site of the protein that has been shown to be associated with non-syndromic deafness (D'Adamo et al., 2003). It was found that the mutant protein had lower ATP hydrolyzing capacity compared to the wild type protein and failed to slide along actin in in vitro motility assays (Yengo et al., 2007). As well, unlike the wild type protein, the mutant proteins failed to localize to the apical protrusions in the polarized LLC-PK1 cell types, thus indicating that the mutation affected its ability to target to appropriate cellular compartments (Yengo et al., 2007). It is possible that in the human patients, inability of the mutant protein to localize properly affects the stability of the cells in the sensory epithelium. However, more in depth studies are necessary to definitively address that point.

\section{Significance}

Myo1c has been shown to play a role in glucose transporter recycling (Bose et al., 2002) and exocytosis (Bose et al., 2004), lamellipodial growth of neuronal cells (Diefenbach et al., 2002) and powering transcription in the nucleus together with RNA Pol II (Pestic-Dragovich et al., 2000), in addition to its role in adaptation in hair cells. Myo1c has also been localized in brush border epithelium in kidney cells (Boyd-White et al., 2001) and is implicated in sodium transport in kidney cell lines (Wagner et al., 2005). The motor properties of Myolc have been shown to be regulated by the $\mathrm{Ca}^{+2}$ and $\mathrm{CaM}$ bound to the IQ domains (Barylko et al., 1992; Zhu et al., 1996; Zhu et al., 1998). Myo1c 
is the slow adaptation motor in hair cells (Holt et al., 2002) and one of the functions attributed to the motor is proper positioning of the mechanotransduction apparatus in the hair bundle (Holt et al., 2002). It is thought that Myolc being an actin-based motor climbs up the actin cytoskeleton in hair bundles exerting force, thus maintaining the transduction channel at the position of maximum sensitivity (reviewed in Gillespie and Cyr, 2004). The importance of the lever arm in force production has not been investigated for Myolc, although the CaM molecules have been clearly shown to confer rigidity on this myosin molecule (Zhu et al., 1996; Zhu et al., 1998). It is the long-term goal of this research to further investigate the role of the neck length of Myolc to better understand its role in hair cell function and various other physiological processes. 


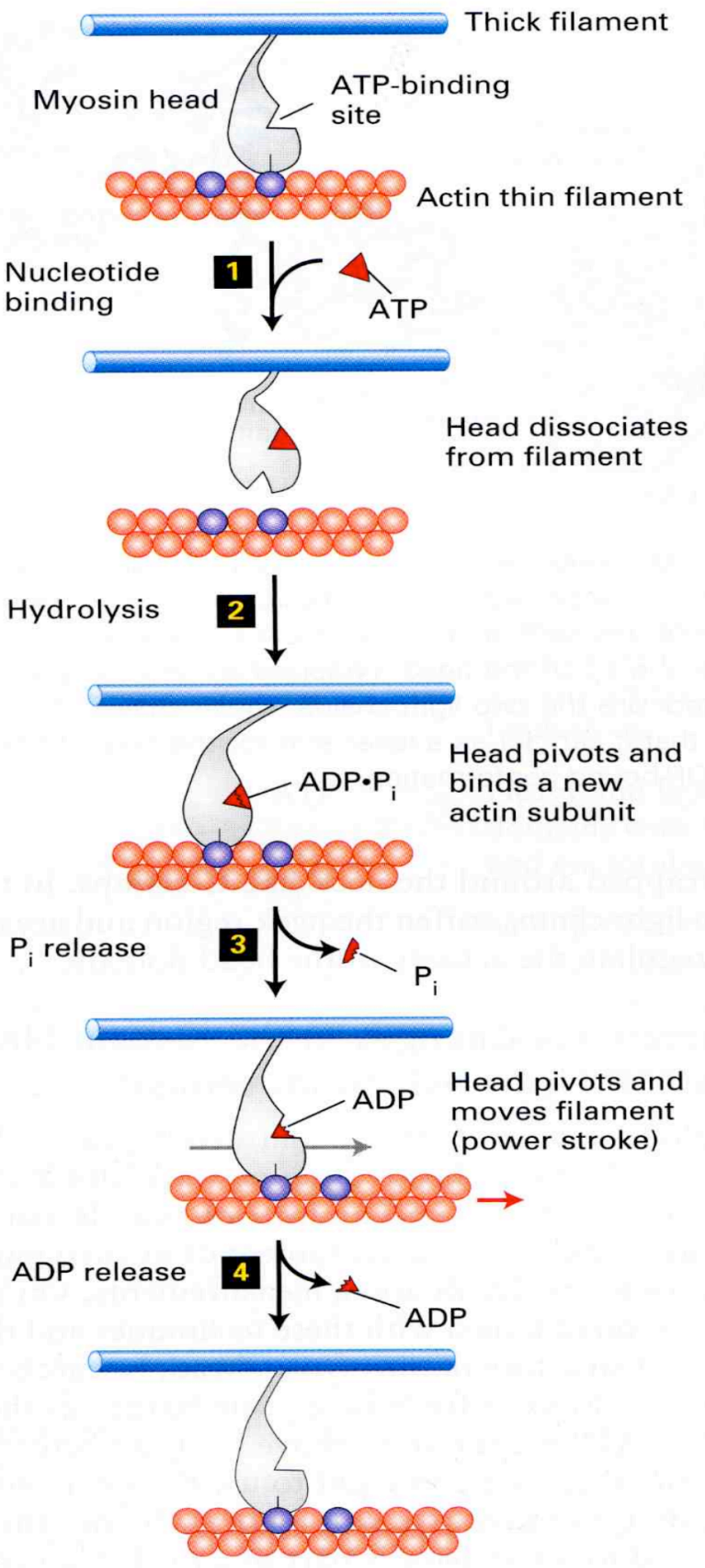

Figure 1. Myosin force generation along actin. Myosin head is bound to actin in a rigor state. In (1), binding of ATP to the myosin head causes it to dissociate from actin. In step (2) hydrolysis of ATP causes myosin to bind actin at a new site with ADP and Pi still bound to it. Release of Pi from the head (3) causes myosin to exert the power stroke along actin and dock to a new site on the latter. In step (4) the bound ADP dissociates from the head. Adapted by permission from W.H. Freeman \& company, Molecular Cell Biology, $5^{\text {th }}$ Edition. 


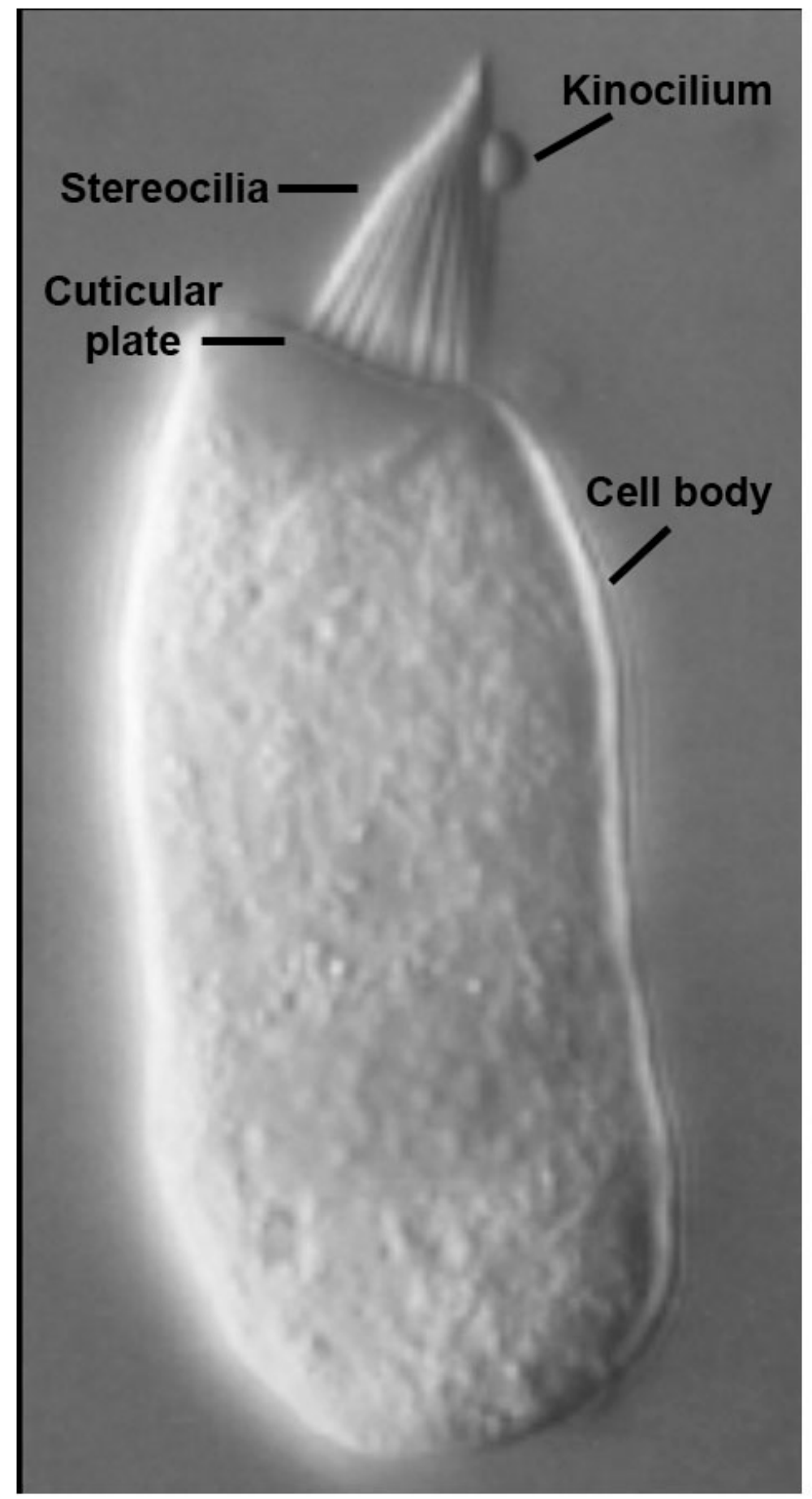

Figure 2. Differential interference contrast image of an isolated bullfrog saccular hair cell showing the stereocilia, kinocilium, the cuticular plate and the cell body. Used with permission from Dr. A.J. Hudspeth, The Rockefeller University, NY. 


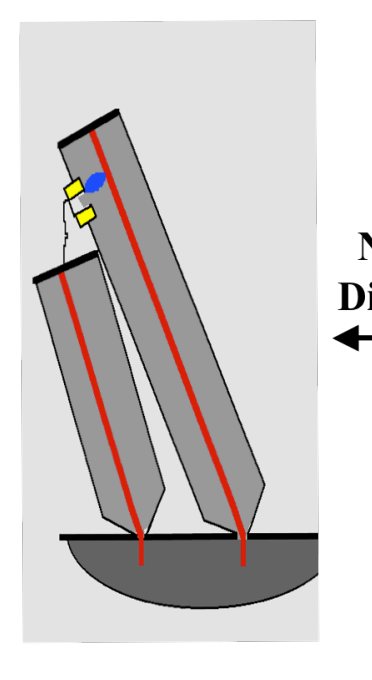

Channel Closes

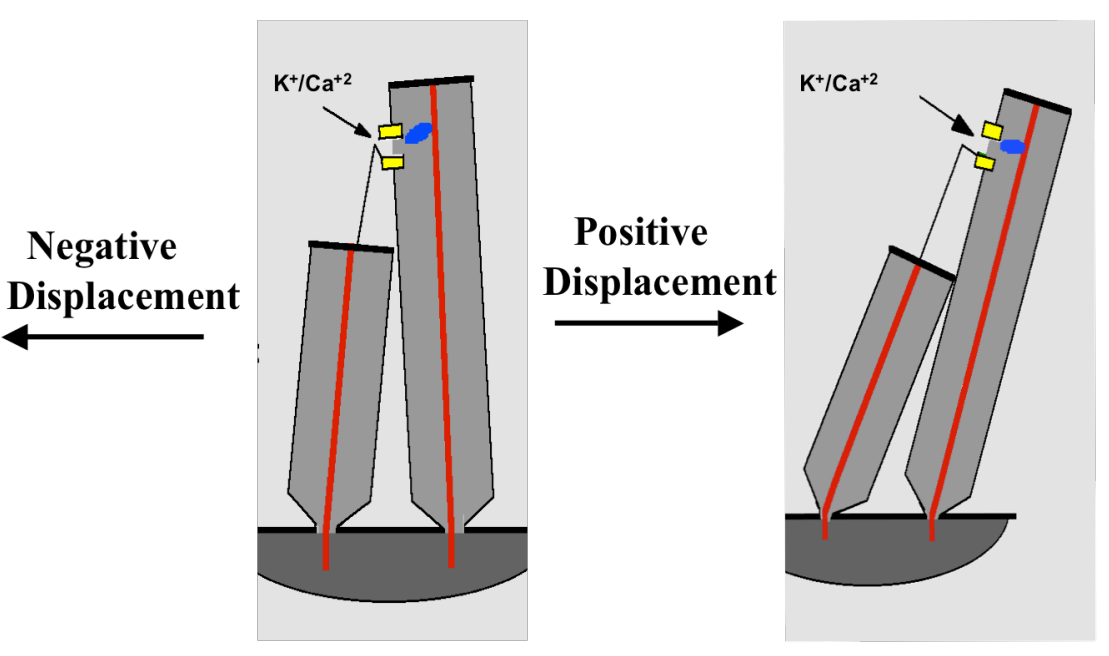

Resting State
Channel Opens

Figure 3. Model for hair cell transduction. A short and a tall stereocilium are depicted in light grey, connected by the gating spring. Red lines represent the actin cytoskeleton. The yellow boxes are the transduction channels and Myo1c is shown in blue. The cuticular plate is depicted in dark grey. Resting state refers to the absence of stimulus. Positive displacement pushes the shorter edge towards the taller edge of the stereocilia, tenses the tip links and opens transduction channels in the membrane. Negative displacement pushes the taller edge of the stereocilia towards the shorter edge, slackens the tip links and closes the channels. Adapted by permission from Macmillan Publishers Ltd: Nature 431. (C) 1999. 


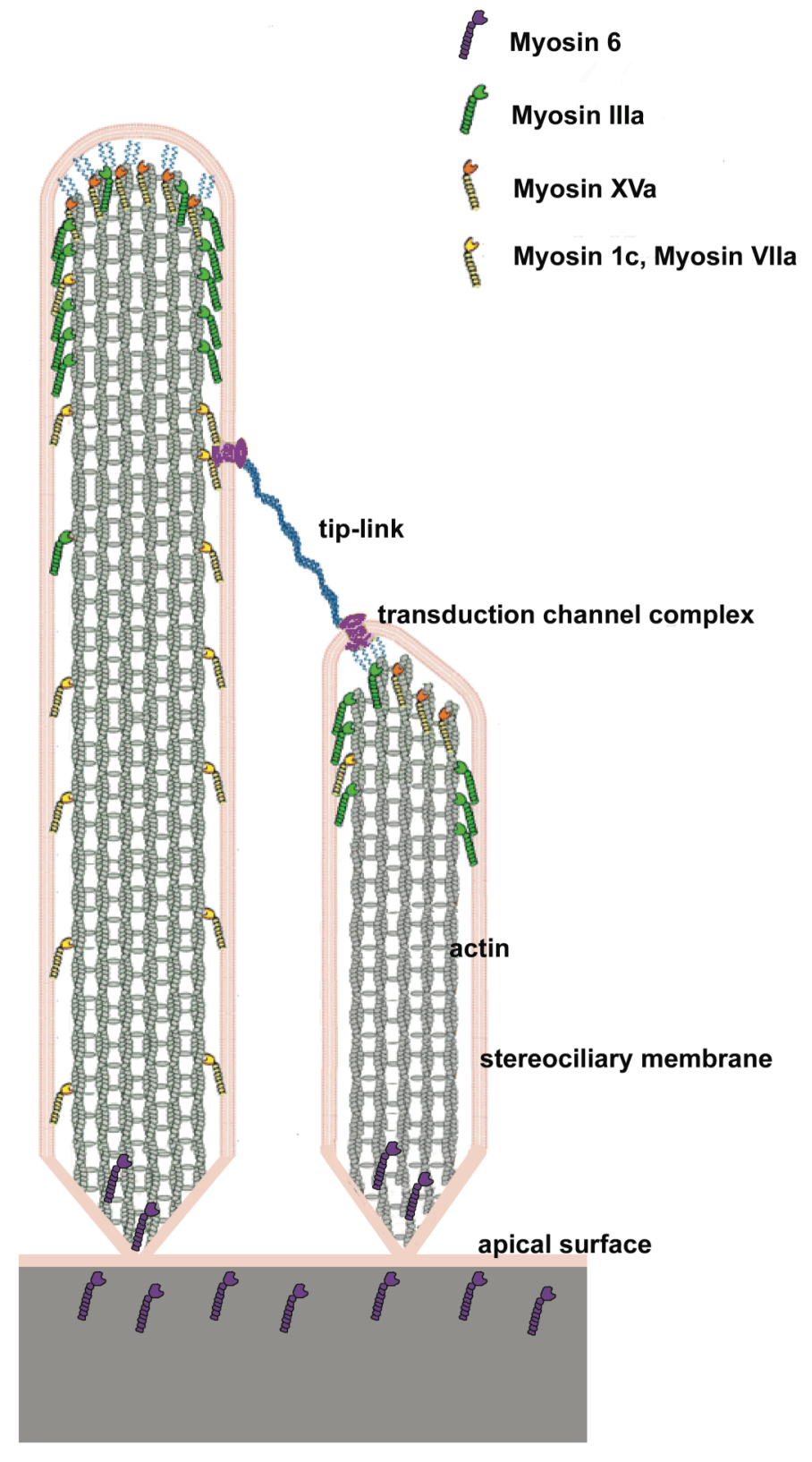

Figure 4. Distribution of myosins in the hair cell stereocilia : Cartoon of two neighboring stereocilia connected by the tip link in blue.The transduction channel complex is depicted in bright pink. Stereociliary membrane is in pink. The different myosin molecules are shown in the top right panel. MyoVI is localized to the cuticular plate region shown in purple. MyoVIIa and Myo1c are depicted in yellow and distributed throughout the stereocilia. Myo3a is localized in a thimble-like pattern at the tips show in green and Myo15a is also present at the tips depicted in orange. The actin cytoskeleton is shown in grey. Diagram is not drawn to scale Used with permission from Kelli R. Phillips, 2007, Characterization of Myosin I in the inner ear. 


\section{References}

Adato A, Michel V, Kikkawa Y, Reiners J, Alagramam KN, Weil D, Yonekawa H, Wolfrum U, El-Amraoui A, Petit C (2005) Interactions in the network of Usher syndrome type 1 proteins. Hum Mol Genet 14:347-356.

Ahmed ZM, Riazuddin S, Bernstein SL, Ahmed Z, Khan S, Griffith AJ, Morell RJ, Friedman TB, Riazuddin S, Wilcox ER (2001) Mutations of the protocadherin gene PCDH15 cause Usher syndrome type 1F. Am J Hum Genet 69:25-34.

Ahmed ZM, Riazuddin S, Ahmad J, Bernstein SL, Guo Y, Sabar MF, Sieving P, Riazuddin S, Griffith AJ, Friedman TB, Belyantseva IA, Wilcox ER (2003) PCDH15 is expressed in the neurosensory epithelium of the eye and ear and mutant alleles are responsible for both USH1F and DFNB23. Hum Mol Genet 12:3215-3223.

Ahmed ZM, Goodyear R, Riazuddin S, Lagziel A, Legan PK, Behra M, Burgess SM, Lilley KS, Wilcox ER, Riazuddin S, Griffith AJ, Frolenkov GI, Belyantseva IA, Richardson GP, Friedman TB (2006) The tip-link antigen, a protein associated with the transduction complex of sensory hair cells, is protocadherin-15. J Neurosci 26:7022-7034.

Alagramam KN, Yuan H, Kuehn MH, Murcia CL, Wayne S, Srisailpathy CR, Lowry RB, Knaus R, Van Laer L, Bernier FP, Schwartz S, Lee C, Morton CC, Mullins RF, Ramesh A, Van Camp G, Hageman GS, Woychik RP, Smith RJ (2001) Mutations in the novel protocadherin PCDH15 cause Usher syndrome type 1F. Hum Mol Genet 10:1709-1718.

Allen RD, Metuzals J, Tasaki I, Brady ST, Gilbert SP (1982) Fast axonal transport in squid giant axon. Science 218:1127-1129.

Anderson DW, Probst FJ, Belyantseva IA, Fridell RA, Beyer L, Martin DM, Wu D, Kachar B, Friedman TB, Raphael Y, Camper SA (2000) The motor and tail regions of myosin $\mathrm{XV}$ are critical for normal structure and function of auditory and vestibular hair cells. Hum Mol Genet 9:1729-1738.

Aschenbrenner L, Naccache SN, Hasson T (2004) Uncoated endocytic vesicles require the unconventional myosin, Myo6, for rapid transport through actin barriers. Mol Biol Cell 15:2253-2263.

Assad JA, Shepherd GMG, Corey DP (1991) Tip-link integrity and mechanical transduction in vertebrate hair cells. Neuron 7:985-994.

Assad JA, Corey DP (1992) An active motor model for adaptation by vertebrate hair cells. J Neurosci 12:3291-3309.

Avraham KB, Hasson T, Steel KP, Kingsley DM, Russell LB (1995) The mouse Snell's waltzer deafness gene encodes an unconventional myosin. Nature Genetics 11:369-375.

Bahler M, Rhoads A (2002) Calmodulin signaling via the IQ motif. FEBS Lett 513:107113.

Bahloul A, Chevreux G, Wells AL, Martin D, Nolt J, Yang Z, Chen LQ, Potier N, Van Dorsselaer A, Rosenfeld S, Houdusse A, Sweeney HL (2004) The unique insert in myosin VI is a structural calcium-calmodulin binding site. Proc Natl Acad Sci U S A 101:4787-4792. 
Barylko B, Wagner MC, Reizes O, Albanesi JP (1992) Purification and characterization of a mammalian myosin I. Proc Natl Acad Sci USA 89, 490-494.

Bautista DM, Jordt SE, Nikai T, Tsuruda PR, Read AJ, Poblete J, Yamoah EN, Basbaum AI, Julius D (2006) TRPA1 mediates the inflammatory actions of environmental irritants and proalgesic agents. Cell 124:1269-1282.

Belyantseva IA, Boger ET, Naz S, Frolenkov GI, Sellers JR, Ahmed ZM, Griffith AJ, Friedman TB (2005) Myosin-XVa is required for tip localization of whirlin and differential elongation of hair-cell stereocilia. Nat Cell Biol 7:148-156.

Boeda B, El-Amraoui A, Bahloul A, Goodyear R, Daviet L, Blanchard S, Perfettini I, Fath KR, Shorte S, Reiners J, Houdusse A, Legrain P, Wolfrum U, Richardson G, Petit C (2002) Myosin VIIa, harmonin and cadherin 23, three Usher I gene products that cooperate to shape the sensory hair cell bundle. Embo J 21:66896699.

Bolz H, von Brederlow B, Ramirez A, Bryda EC, Kutsche K, Nothwang HG, Seeliger M, del CSCM, Vila MC, Molina OP, Gal A, Kubisch C (2001) Mutation of CDH23, encoding a new member of the cadherin gene family, causes Usher syndrome type 1D. Nat Genet 27:108-112.

Bork JM, Peters LM, Riazuddin S, Bernstein SL, Ahmed ZM, Ness SL, Polomeno R, Ramesh A, Schloss M, Srisailpathy CR, Wayne S, Bellman S, Desmukh D, Ahmed Z, Khan SN, Kaloustian VM, Li XC, Lalwani A, Riazuddin S, BitnerGlindzicz M, Nance WE, Liu XZ, Wistow G, Smith RJ, Griffith AJ, Wilcox ER, Friedman TB, Morell RJ (2001) Usher syndrome 1D and nonsyndromic autosomal recessive deafness DFNB12 are caused by allelic mutations of the novel cadherin-like gene CDH23. Am J Hum Genet 68:26-37.

Bose A, Robida S, Furcinitti PS, Chawla A, Fogarty K, Corvera S, Czech MP (2004) Unconventional myosin Myolc promotes membrane fusion in a regulated exocytic pathway. Mol Cell Biol 24:5447-5458.

Bose A, Guilherme A, Robida SI, Nicoloro SM, Zhou QL, Jiang ZY, Pomerleau DP, Czech MP (2002) Glucose transporter recycling in response to insulin is facilitated by myosin Myo1c. Nature 420:821-824.

Boyd-White J, Srirangam A, Goheen MP, Wagner MC (2001) Ischemia disrupts myosin I beta in renal tubules. Am J Physiol Cell Physiol 281:C1326-1335.

Brady ST (1985) A novel brain ATPase with properties expected for the fast axonal transport motor. Nature 317:73-75.

Brady ST, Lasek RJ, Allen RD (1985) Video microscopy of fast axonal transport in extruded axoplasm: a new model for study of molecular mechanisms. Cell Motil 5:81-101.

Colclasure JC, Holt JR (2003) Transduction and adaptation in sensory hair cells of the mammalian vestibular system. Gravit Space Biol Bull 16:61-70.

Coluccio LM (1991) Identification of the microvillar 110-kDa calmodulin complex (myosin-1) in kidney. Eur J Cell Biol 56:286-294.

Corey DP (2006) What is the hair cell transduction channel? J Physiol 576:23-28.

Corey DP, Hudspeth AJ (1979) Ionic basis of the receptor potential in a vertebrate hair cell. Nature 281:675-677.

Corey DP, Hudspeth AJ (1983) Kinetics of the receptor current in bullfrog saccular hair cells. J Neurosci 3:962-976. 
Corey DP, Garcia-Anoveros J, Holt JR, Kwan KY, Lin SY, Vollrath MA, Amalfitano A, Cheung EL, Derfler BH, Duggan A, Geleoc GS, Gray PA, Hoffman MP, Rehm HL, Tamasauskas D, Zhang DS (2004) TRPA1 is a candidate for the mechanosensitive transduction channel of vertebrate hair cells. Nature 432:723730 .

Cuajungco MP, Grimm C, Heller S (2007) TRP channels as candidates for hearing and balance abnormalities in vertebrates. Biochim Biophys Acta 1772:1022-1027.

Cyr JL, Dumont RA, Gillespie PG (2002) Myosin-1c interacts with hair-cell receptors through its calmodulin-binding IQ domains. J Neurosci 22:2487-2495.

D'Adamo P, Pinna M, Capobianco S, Cesarani A, D'Eustacchio A, Fogu P, Carella M, Seri M, Gasparini P (2003) A novel autosomal dominant non-syndromic deafness locus (DFNA48) maps to 12q13-q14 in a large Italian family. Hum Genet 112:319-320.

Denk W, Holt JR, Shepherd GM, Corey DP (1995) Calcium imaging of single stereocilia in hair cells: localization of transduction channels at both ends of tip links. Neuron 15:1311-1321.

Deol MS, Green MC (1966) Snell's waltzer, a new mutation affecting behaviour and the inner ear in the mouse. Genet Res 8:339-345.

Di Palma F, Belyantseva IA, Kim HJ, Vogt TF, Kachar B, Noben-Trauth K (2002) Mutations in Mcoln3 associated with deafness and pigmentation defects in varitint-waddler (Va) mice. Proc Natl Acad Sci U S A 99:14994-14999.

Di Palma F, Holme RH, Bryda EC, Belyantseva IA, Pellegrino R, Kachar B, Steel KP, Noben-Trauth K (2001) Mutations in Cdh23, encoding a new type of cadherin, cause stereocilia disorganization in waltzer, the mouse model for Usher syndrome type 1D. Nat Genet 27:103-107.

Diefenbach TJ, Latham VM, Yimlamai D, Liu CA, Herman IM, Jay DG (2002) Myosin $1 \mathrm{c}$ and myosin IIB serve opposing roles in lamellipodial dynamics of the neuronal growth cone. J Cell Biol 158:1207-1217.

Donaudy F, Ferrara A, Esposito L, Hertzano R, Ben-David O, Bell RE, Melchionda S, Zelante L, Avraham KB, Gasparini P (2003) Multiple mutations of MYO1A, a cochlear-expressed gene, in sensorineural hearing loss. Am J Hum Genet $72: 1571-1577$.

Dose AC, Burnside B (2000) Cloning and chromosomal localization of a human class III myosin. Genomics 67:333-342.

Eatock RA (2000) Adaptation in hair cells. Annu Rev Neurosci 23:285-314.

Etournay R, Zwaenepoel I, Perfettini I, Legrain P, Petit C, El-Amraoui A (2007) Shroom2, a myosin-VIIa- and actin-binding protein, directly interacts with ZO-1 at tight junctions. J Cell Sci 120:2838-2850.

Etournay R, El-Amraoui A, Bahloul A, Blanchard S, Roux I, Pezeron G, Michalski N, Daviet L, Hardelin JP, Legrain P, Petit C (2005) PHR1, an integral membrane protein of the inner ear sensory cells, directly interacts with myosin 1c and myosin VIIa. J Cell Sci 118:2891-2899.

Foth BJ, Goedecke MC, Soldati D (2006) New insights into myosin evolution and classification. Proc Natl Acad Sci U S A 103:3681-3686.

Friedman TB, Sellers JR, Avraham KB (1999) Unconventional myosins and the genetics of hearing loss. Am J Med Genet 89:147-157. 
Garcia JA, Yee AG, Gillespie PG, Corey DP (1998) Localization of myosin-Ibeta near both ends of tip links in frog saccular hair cells. J Neurosci 18 : 8637-8647.

Gillespie PG, Hudspeth AJ (1993) Adenine nucleoside diphosphates block adaptation of mechanoelectrical transduction in hair cells. Proc Natl Acad Sci USA 90:27102714.

Gillespie PG, Corey DP (1997) Myosin and adaptation by hair cells. Neuron 19:955-958.

Gillespie PG, Walker RG (2001) Molecular basis of mechanosensory transduction. Nature 413:194-202.

Gillespie PG, Cyr JL (2004) Myosin-1c, the hair cell's adaptation motor. Annu Rev Physiol 66:521-545.

Gillespie PG, Wagner MC, Hudspeth AJ (1993) Identification of a 120 kd hair-bundle myosin located near stereociliary tips. Neuron 11:581-594.

Gillespie PG, Gillespie SK, Mercer JA, Shah K, Shokat KM (1999) Engineering of the myosin-I $\beta$ nucleotide-binding pocket to create selective sensitivity to $\mathrm{N}^{6}$-modified ADP analogs. J Biol Chem 274:31373-31381.

Glowatzki E (1997) Analysis of gene expression in the organ of Corti revealed by singlecell RT-PCR. Audiol Neurootol 2:71-78.

Gong Z, Son W, Chung YD, Kim J, Shin DW, McClung CA, Lee Y, Lee HW, Chang DJ, Kaang BK, Cho H, Oh U, Hirsh J, Kernan MJ, Kim C (2004) Two interdependent TRPV channel subunits, inactive and Nanchung, mediate hearing in Drosophila. J Neurosci 24:9059-9066.

Goodyear RJ, Richardson GP (2003) A novel antigen sensitive to calcium chelation that is associated with the tip links and kinocilial links of sensory hair bundles. $\mathrm{J}$ Neurosci 23:4878-4887.

Halliburton WD (1887) On Muscle-Plasma. J Physiol 8:133-202.

Hasson T, Gillespie PG, Garcia JA, MacDonald RB, Zhao Y, Yee AG, Corey DP (1997) Unconventional myosins in inner-ear sensory epithelia. J Cell Biol 137:12871307.

Harteneck C, Plant TD, Schultz G (2000) From worm to man: three subfamilies of TRP channels. Trends Neurosci 23:159-166.

Hasson T, Mooseker MS (1994) Porcine myosin-VI: characterization of a new mammalian unconventional. Journal of Cell Biology 127:425-440.

Hirono M, Denis CS, Richardson GP, Gillespie PG (2004) Hair cells require phosphatidylinositol 4,5-bisphosphate for mechanical transduction and adaptation. Neuron 44:309-320.

Hokanson DE, Ostap EM (2006) Myo1c binds tightly and specifically to phosphatidylinositol 4,5-bisphosphate and inositol 1,4,5-trisphosphate. Proc Natl Acad Sci U S A 103:3118-3123.

Holt JR, Corey DP (2000) Two mechanisms for transducer adaptation in vertebrate hair cells. Proc Natl Acad Sci U S A 97:11730-11735.

Holt JR, Corey DP, Eatock RA (1997) Mechanoelectrical transduction and adaptation in hair cells of the mouse utricle, a low-frequency vestibular organ. J Neurosci 17:8739-8748.

Holt JR, Gillespie SK, Provance DW, Shah K, Shokat KM, Corey DP, Mercer JA, Gillespie PG (2002) A chemical-genetic strategy implicates myosin-1c in adaptation by hair cells. Cell 108:371-381. 
Holton T, Hudspeth AJ (1983) A micromechanical contribution to cochlear tuning and tonotopic organization. Science 222:508-510.

Holton T, Hudspeth AJ (1986) The transduction channels of hair cells from the bull-frog characterized by noise analysis. J Physiol 375: 195-227.

Howard J, Hudspeth AJ (1988) Complianceof the hair-bundle associated with gating of mechanoelectrical transduction channels in the bullfrog's sacuular hair cell. Cell $108: 371-381$.

Howard J, Bechstedt S (2004) Hypothesis: a helix of ankyrin repeats of the NOMPC-TRP ion channel is the gating spring of mechanoreceptors. Curr Biol 14:R224-226.

Hudspeth AJ (1985) Models for mechanoelectrical transduction by hair cells. Prog Clin Biol Res 176:193-205.

Hudspeth AJ (1989a) Mechanoelectrical transduction by hair cells of the bullfrog's sacculus. Prog Brain Res 80:129-135.

Hudspeth AJ (1989b) How the ear's works work. Nature 341:397-404.

Hudspeth AJ (1992) Hair-bundle mechanics and a model for mechanoelectrical transduction by hair cells. Soc Gen Physiol Ser 47:357-370.

Hudspeth AJ (1997) How hearing happens. Neuron 19:947-950.

Hudspeth AJ, Jacobs R (1979) Stereocilia mediate transduction in vertebrate hair cells (auditory system/cilium/vestibular system). Proc Natl Acad Sci U S A 76:15061509.

Hudspeth AJ, Choe Y, Mehta AD, Martin P (2000) Putting ion channels to work: mechanoelectrical transduction, adaptation, and amplification by hair cells. Proc Natl Acad Sci U S A 97:11765-11772.

Imamura S, Adams JC (2003) Changes in cytochemistry of sensory and nonsensory cells in gentamicin-treated cochleas. J Assoc Res Otolaryngol 4:196-218.

Inoue A, Ikebe M (2003) Characterization of the motor activity of mammalian myosin VIIA. J Biol Chem 278:5478-5487.

Kachar B, Parakkal M, Kurc M, Zhao Y, Gillespie PG (2000) High-resolution structure of hair-cell tip links. Proc Natl Acad Sci U S A 97:13336-13341.

Kappler JA, Starr CJ, Chan DK, Kollmar R, Hudspeth AJ (2004) A nonsense mutation in the gene encoding a zebrafish myosin VI isoform causes defects in hair-cell mechanotransduction. Proc Natl Acad Sci U S A 101:13056-13061.

Kawamoto K, Sha SH, Minoda R, Izumikawa M, Kuriyama H, Schacht J, Raphael Y (2004) Antioxidant gene therapy can protect hearing and hair cells from ototoxicity. Mol Ther 9:173-181.

Kazmierczak P, Sakaguchi H, Tokita J, Wilson-Kubalek EM, Milligan RA, Muller U, Kachar B (2007) Cadherin 23 and protocadherin 15 interact to form tip-link filaments in sensory hair cells. Nature 449:87-91.

Kellerman KA, Miller KG (1992) An unconventional myosin heavy chain gene from Drosophila melanogaster. J Cell Biol 119:823-834.

Kelley MW, Ochiai CK, Corwin JT (1992) Maturation of kinocilia in amphibian hair cells: growth and shortening related to kinociliary bulb formation. Hear Res 59:108-115.

Kikkawa Y, Mburu P, Morse S, Kominami R, Townsend S, Brown SD (2005) Mutant analysis reveals whirlin as a dynamic organizer in the growing hair cell stereocilium. Hum Mol Genet 14:391-400. 
Kim J, Chung YD, Park DY, Choi S, Shin DW, Soh H, Lee HW, Son W, Yim J, Park CS, Kernan MJ, Kim C (2003) A TRPV family ion channel required for hearing in Drosophila. Nature 424:81-84.

Komaba S, Inoue A, Maruta S, Hosoya H, Ikebe M (2003) Determination of human myosin III as a motor protein having a protein kinase activity. J Biol Chem 278:21352-21360.

Kroese AB, Das A, Hudspeth AJ (1989) Blockage of the transduction channels of hair cells in the bullfrog's sacculus by aminoglycoside antibiotics. Hear Res 37:203217.

Kros CJ, Marcotti W, van Netten SM, Self TJ, Libby RT, Brown SD, Richardson GP, Steel KP (2002) Reduced climbing and increased slipping adaptation in cochlear hair cells of mice with Myo7a mutations. Nat Neurosci 5:41-47.

Kussel-Andermann P, El-Amraoui A, Safieddine S, Nouaille S, Perfettini I, Lecuit M, Cossart P, Wolfrum U, Petit C (2000) Vezatin, a novel transmembrane protein, bridges myosin VIIA to the cadherin-catenins complex. Embo J 19:6020-6029.

Kühne, W. (1859) Arch. f. Anat. Physiol. u. wissensch. Med. 748.

Kwan KY, Allchorne AJ, Vollrath MA, Christensen AP, Zhang DS, Woolf CJ, Corey DP (2006) TRPA1 contributes to cold, mechanical, and chemical nociception but is not essential for hair-cell transduction. Neuron 50:277-289.

Lagziel A, Ahmed ZM, Schultz JM, Morell RJ, Belyantseva IA, Friedman TB (2005) Spatiotemporal pattern and isoforms of cadherin 23 in wild type and waltzer mice during inner ear hair cell development. Dev Biol 280:295-306.

Liang Y, Wang A, Belyantseva IA, Anderson DW, Probst FJ, Barber TD, Miller W, Touchman JW, Jin L, Sullivan SL, Sellers JR, Camper SA, Lloyd RV, Kachar B, Friedman TB, Fridell RA (1999) Characterization of the human and mouse unconventional myosin XV genes responsible for hereditary deafness DFNB3 and shaker 2. Genomics 61: 243-258.

Liedtke W, Choe Y, Marti-Renom MA, Bell AM, Denis CS, Sali A, Hudspeth AJ, Friedman JM, Heller S (2000) Vanilloid receptor-related osmotically activated channel (VR-OAC), a candidate vertebrate osmoreceptor. Cell 103:525-535.

Lin T, Tang N, Ostap EM (2005) Biochemical and motile properties of myolb splice isoforms. J Biol Chem 280:41562-41567.

Lumpkin EA, Marquis RE, Hudspeth AJ (1997) The selectivity of the hair cell's mechanoelectrical-transduction channel promotes $\mathrm{Ca} 2+$ flux at low $\mathrm{Ca} 2+$ concentrations. Proc Natl Acad Sci U S A 94:10997-11002.

Manceva S, Lin T, Pham H, Lewis JH, Goldman YE, Ostap EM (2007) Calcium Regulation of Calmodulin Binding to and Dissociation from the Myolc Regulatory Domain. Biochemistry.

Markin VS, Hudspeth AJ (1995) Gating-spring models of mechanoelectrical transduction by hair cells of the internal ear. Annu Rev Biophys Biomol Struct 24 : 59-83.

Marquis RE, Hudspeth AJ (1997) Effects of extracellular $\mathrm{Ca}^{2+}$ concentration on hairbundle stiffness and gating-spring integrity in hair cells. Proc Natl Acad Sci U S A 94:11923-11928.

Mburu P, Liu XZ, Walsh J, Saw D, Jr., Cope MJ, Gibson F, Kendrick-Jones J, Steel KP, Brown SD (1997) Mutation analysis of the mouse myosin VIIA deafness gene. Genes Funct 1:191-203. 
Mburu P, Mustapha M, Varela A, Weil D, El-Amraoui A, Holme RH, Rump A, Hardisty RE, Blanchard S, Coimbra RS, Perfettini I, Parkinson N, Mallon AM, Glenister P, Rogers MJ, Paige AJ, Moir L, Clay J, Rosenthal A, Liu XZ, Blanco G, Steel KP, Petit C, Brown SD (2003) Defects in whirlin, a PDZ domain molecule involved in stereocilia elongation, cause deafness in the whirler mouse and families with DFNB31. Nat Genet 34:421-428.

Melchionda S, Ahituv N, Bisceglia L, Sobe T, Glaser F, Rabionet R, Arbones ML, Notarangelo A, Di Iorio E, Carella M, Zelante L, Estivill X, Avraham KB, Gasparini P (2001) MYO6, the human homologue of the gene responsible for deafness in Snell's waltzer mice, is mutated in autosomal dominant nonsyndromic hearing loss. Am J Hum Genet 69:635-640.

Metcalf AB (1998) Immunolocalization of myosin Ibeta in the hair cell's hair bundle. Cell Motil Cytoskeleton 39:159-165.

Michel V, Goodyear RJ, Weil D, Marcotti W, Perfettini I, Wolfrum U, Kros CJ, Richardson GP, Petit C (2005) Cadherin 23 is a component of the transient lateral links in the developing hair bundles of cochlear sensory cells. Dev Biol 280:281294.

Moore JR, Krementsova EB, Trybus KM, Warshaw DM (2004) Does the myosin V neck region act as a lever? J Muscle Res Cell Motil 25:29-35.

Mooseker MS (1985) Organization, chemistry, and assembly of the cytoskeletal apparatus of the intestinal brush border. Annu Rev Cell Biol 1:209-241.

Mooseker MS, Cheney RE (1995a) Unconventional myosins. Annu Rev Cell Dev Biol 11:633-675.

Mooseker MS, Cheney RE (1995b) Unconventional myosins. Ann Rev Cell Devel Biol 11:633-675.

Ng KP, Kambara T, Matsuura M, Burke M, Ikebe M (1996) Identification of myosin III as a protein kinase. Biochemistry 35:9392-9399.

Noben-Trauth K, Zheng QY, Johnson KR (2003) Association of cadherin 23 with polygenic inheritance and genetic modification of sensorineural hearing loss. Nat Genet 35:21-23.

Park H, Li A, Chen LQ, Houdusse A, Selvin PR, Sweeney HL (2007) The unique insert at the end of the myosin VI motor is the sole determinant of directionality. Proc Natl Acad Sci U S A 104:778-783.

Pestic-Dragovich L, Stojiljkovic L, Philimonenko AA, Nowak G, Ke Y, Settlage RE, Shabanowitz J, Hunt DF, Hozak P, de Lanerolle P (2000) A myosin I isoform in the nucleus. Science 290:337-341.

Phillips KR, Tong S, Goodyear R, Richardson GP, Cyr JL (2006) Stereociliary myosin1c receptors are sensitive to calcium chelation and absent from cadherin 23 mutant mice. J Neurosci 26:10777-10788.

Pickles JO, Comis SD, Osborne MP (1984) Cross-links between stereocilia in the guinea pig organ of Corti and their possible relation to sensory transduction. Hearing Res 15:103-112.

Pickles JO, Rouse GW, von Perger M (1991) Morphological correlates of mechanotransduction in acousticolateral hair cells. Scanning Microscopy 5:11151129. 
Pollard TD, Korn ED (1973a) Acanthamoeba myosin I. Isolation from Acanthamoeba castellanii of an enzyme similar to muscle myosin. J Biol Chem 248:4682-4690.

Pollard TD, Korn ED (1973b) Acanthamoeba myosin. II. Interaction with actin and with a new cofactor protein required for actin activation of $\mathrm{Mg} \mathrm{2}+$ adenosine triphosphatase activity. J Biol Chem 248:4691-4697.

Porter JA, Montell C (1993) Distinct roles of the Drosophila ninaC kinase and myosin domains revealed by systematic mutagenesis. J Cell Biol 122:601-612.

Purcell TJ, Morris C, Spudich JA, Sweeney HL (2002) Role of the lever arm in the processive stepping of myosin V. Proc Natl Acad Sci U S A 99:14159-14164.

Reizes O, Barylko B, Li C, Sudhof TC, Albanesi JP (1994) Domain structure of a mammalian myosin I beta. Proc Natl Acad Sci U S A 91:6349-6353.

Rhoads AR, Friedberg F (1997) Sequence motifs for calmodulin recognition. Faseb J 11:331-340.

Ricci A (2003) Active hair bundle movements and the cochlear amplifier. J Am Acad Audiol 14:325-338.

Ricci AJ, Fettiplace R (1997) The effects of calcium buffering and cyclic AMP on mechano-electrical transduction in turtle auditory hair cells. J Physiol (Lond) 501:111-124.

Ricci AJ, Crawford AC, Fettiplace R (2000) Active hair bundle motion linked to fast transducer adaptation in auditory hair cells. J Neurosci 20:7131-7142.

Ricci AJ, Kachar B, Gale J, Van Netten SM (2006) Mechano-electrical transduction: new insights into old ideas. J Membr Biol 209:71-88.

Rock RS, Rice SE, Wells AL, Purcell TJ, Spudich JA, Sweeney HL (2001) Myosin VI is a processive motor with a large step size. Proc Natl Acad Sci U S A 98:1365513659.

Rogat AD, Miller KG (2002) A role for myosin VI in actin dynamics at sites of membrane remodeling during Drosophila spermatogenesis. J Cell Sci 115:48554865.

Rusch A, Hummler E (1999) Mechano-electrical transduction in mice lacking the alphasubunit of the epithelial sodium channel. Hear Res 131:170-176.

Sakamoto T, Yildez A, Selvin PR, Sellers JR (2005) Step-size is determined by neck length in myosin V. Biochemistry 44:16203-16210.

Schnapp BJ, Vale RD, Sheetz MP, Reese TS (1985) Single microtubules from squid axoplasm support bidirectional movement of organelles. Cell 40:455-462.

Schneider ME, Dose AC, Salles FT, Chang W, Erickson FL, Burnside B, Kachar B (2006) A new compartment at stereocilia tips defined by spatial and temporal patterns of myosin IIIa expression. J Neurosci 26:10243-10252.

Schott DH, Collins RN, Bretscher A (2002) Secretory vesicle transport velocity in living cells depends on the myosin-V lever arm length. J Cell Biol 156:35-39.

Seiler C, Ben-David O, Sidi S, Hendrich O, Rusch A, Burnside B, Avraham KB, Nicolson T (2004) Myosin VI is required for structural integrity of the apical surface of sensory hair cells in zebrafish. Dev Biol 272:328-338.

Self T, Sobe T, Copeland NG, Jenkins NA, Avraham KB, Steel KP (1999) Role of myosin VI in the differentiation of cochlear hair cells. Dev Biol 214:331-341.

Sellers JR (1999) Myosins. Oxford University Press, Oxford.

Sellers JR (2000) Myosins: a diverse superfamily. Biochim Biophys Acta 1496:3-22. 
Senften M, Schwander M, Kazmierczak P, Lillo C, Shin JB, Hasson T, Geleoc GS, Gillespie PG, Williams D, Holt JR, Muller U (2006) Physical and functional interaction between protocadherin 15 and myosin VIIa in mechanosensory hair cells. J Neurosci 26:2060-2071.

Sheetz MP, Spudich JA (1983a) Movement of myosin-coated fluorescent beads on actin cables in vitro. Nature 303:31-35.

Sheetz MP, Spudich JA (1983b) Movement of myosin-coated structures on actin cables. Cell Motil 3:485-489.

Shin JB, Adams D, Paukert M, Siba M, Sidi S, Levin M, Gillespie PG, Grunder S (2005) Xenopus TRPN1 (NOMPC) localizes to microtubule-based cilia in epithelial cells, including inner-ear hair cells. Proc Natl Acad Sci U S A 102:12572-12577.

Sidi S, Friedrich RW, Nicolson T (2003) NompC TRP channel required for vertebrate sensory hair cell mechanotransduction. Science 301:96-99.

Siemens J, Lillo C, Dumont RA, Reynolds A, Williams DS, Gillespie PG, Muller U (2004) Cadherin 23 is a component of the tip link in hair-cell stereocilia. Nature 428:950-955.

Sollner C, Rauch GJ, Siemens J, Geisler R, Schuster SC, Muller U, Nicolson T (2004) Mutations in cadherin 23 affect tip links in zebrafish sensory hair cells. Nature 428:955-959.

Spudich JA (1994) How molecular motors work. Nature 372:515-518.

Stauffer EA, Scarborough JD, Hirono M, Miller ED, Shah K, Mercer JA, Holt JR, Gillespie PG (2005) Fast adaptation in vestibular hair cells requires myosin-1c activity. Neuron 47:541-553.

Stepanyan R, Belyantseva IA, Griffith AJ, Friedman TB, Frolenkov GI (2006) Auditory mechanotransduction in the absence of functional myosin-XVa. J Physiol 576:801-808.

Steyger PS, Gillespie PG, Baird RA (1998) Myosin Ibeta is located at tip link anchors in vestibular hair bundles. J Neurosci 18: 4603-4615.

Strassmaier M, Gillespie PG (2002) The hair cell's transduction channel. Curr Opin Neurobiol 12:380-386.

Takumida M, Kubo N, Ohtani M, Suzuka Y, Anniko M (2005) Transient receptor potential channels in the inner ear: presence of transient receptor potential channel subfamily 1 and 4 in the guinea pig inner ear. Acta Otolaryngol 125:929-934.

Tanaka H, Homma K, Iwane AH, Katayama E, Ikebe R, Saito J, Yanagida T, Ikebe M (2002) The motor domain determines the large step of myosin-V. Nature 415:192195.

Thompson RF, Langford GM (2002) Myosin superfamily evolutionary history. Anat Rec 268:276-289.

Tilney LG, Tilney MS, DeRosier DJ (1992a) Actin filaments, stereocilia, and hair cells: how cells count and measure. Annu Rev Cell Biol 8:257-274.

Tilney LG, Tilney MS, DeRosier DJ (1992b) Actin filaments, stereocilia, and hair cells: how cells count and measure. Ann Rev Cell Biol 8:257-274.

Tsuprun V, Goodyear RJ, Richardson GP (2004) The structure of tip links and kinocilial links in avian sensory hair bundles. Biophys J 87:4106-4112.

Tyska MJ, Mooseker MS (2002) MYO1A (brush border myosin I) dynamics in the brush border of LLC-PK1-CL4 cells. Biophys J 82:1869-1883. 
Tyska MJ, Mackey AT, Huang JD, Copeland NG, Jenkins NA, Mooseker MS (2005) Myosin-1a is critical for normal brush border structure and composition. Mol Biol Cell 16:2443-2457.

Udovichenko IP, Gibbs D, Williams DS (2002) Actin-based motor properties of native myosin VIIa. J Cell Sci 115:445-450.

Uyeda TQ, Abramson PD, Spudich JA (1996) The neck region of the myosin motor domain acts as a lever arm to generate movement. Proc Natl Acad Sci U S A 93:4459-4464.

Vale RD, Reese TS, Sheetz MP (1985a) Identification of a novel force-generating protein, kinesin, involved in microtubule-based motility. Cell 42:39-50.

Vale RD, Schnapp BJ, Reese TS, Sheetz MP (1985b) Movement of organelles along filaments dissociated from the axoplasm of the squid giant axon. Cell 40:449-454.

Wagner MC, Blazer-Yost BL, Boyd-White J, Srirangam A, Pennington J, Bennett S (2005) Expression of the unconventional myosin Myolc alters sodium transport in M1 collecting duct cells. Am J Physiol Cell Physiol 289:C120-129.

Walker RG, Willingham AT, Zuker CS (2000) A Drosophila mechanosensory transduction channel. Science 287:2229-2234.

Walsh T, Walsh V, Vreugde S, Hertzano R, Shahin H, Haika S, Lee MK, Kanaan M, King MC, Avraham KB (2002) From flies' eyes to our ears: mutations in a human class III myosin cause progressive nonsyndromic hearing loss DFNB30. Proc Natl Acad Sci U S A 99:7518-7523.

Wang A, Liang Y, Fridell RA, Probst FJ, Wilcox ER, Touchman JW, Morton CC, Morell RJ, Noben-Trauth K, Camper SA, Friedman TB (1998) Association of unconventional myosin MYO15 mutations with human nonsyndromic deafness DFNB3. Science 280:1447-1451.

Weil D, Kussel P, Blanchard S, Levy G, Levi-Acobas F, Drira M, Ayadi H, Petit C (1997) The autosomal recessive isolated deafness, DFNB2, and the Usher 1B syndrome are allelic defects of the myosin-VIIA gene. Nat Genet 16:191-193.

Weil D, Blanchard S, Kaplan J, Guilford P, Gibson F, Walsh J, Mburu P, Varela A, Levilliers J, Weston MD, et al. (1995) Defective myosin VIIA gene responsible for Usher syndrome type 1B. Nature 374:60-61.

Wells AL, Lin AW, Chen LQ, Safer D, Cain SM, Hasson T, Carragher BO, Milligan RA, Sweeney HL (1999) Myosin VI is an actin-based motor that moves backwards. Nature 401:505-508.

Wolenski JS (1995) Regulation of calmodulin-binding myosins. trends Cell Biol 5:310316.

Wu YC, Ricci AJ, Fettiplace R (1999) Two components of transducer adaptation in auditory hair cells. J Neurophysiol 82:2171-2181.

Xu S, Wang, Y, Zhao H, Zhang L, Xiong W, Yau K-W, Hiel H, Glowatzki E, Ryugo DK, Valle D (2004) PHRI, a PH domain -containing protein expressed in primary sensory neurons. Mol Cell Biol 24 (20): 9137-9151.

Yengo CM, Ananthanarayanan SK, Brosey CA, Mao S, Tyska MJ (2007) Human deafness mutation E385D disrupts the mechanochemical coupling and subcellular targeting of myosin-1a. Biophys J. 
Zhao Y, Yamoah EN, Gillespie PG (1996) Regeneration of broken tip links and restoration of mechanical transduction in hair cells. Proc Natl Acad Sci U S A 93:15469-15474.

Zheng L, Sekerkova G, Vranich K, Tilney LG, Mugnaini E, Bartles JR (2000) The deaf jerker mouse has a mutation in the gene encoding the espin actin-bundling proteins of hair cell stereocilia and lacks espins. Cell 102:377-385.

Zhu T, Sata M, Ikebe M (1996) Functional expression of mammalian myosin I beta: analysis of its motor activity. Biochemistry 35:513-522.

Zhu T, Beckingham K, Ikebe M (1998) High affinity Ca2+ binding sites of calmodulin are critical for the regulation of myosin Ibeta motor function. J Biol Chem 273:20481-20486. 


\section{Designing truncated constructs of Myosin 1c and purification of proteins}

\section{Introduction}

All unconventional myosins studied to date have IQ consensus sequences $\left(\mathrm{IQX}_{3} \mathrm{RGX}_{3} \mathrm{R}\right)$ (Rhoads and Friedberg, 1997) in their neck domains following the motor heads. These IQ domains bind the cellular protein calmodulin (CaM) either in the presence or absence of $\mathrm{Ca}^{+2}$ (Garcia et al., 1989; Espreafico et al., 1992; Bahler et al., 1994; Porter et al., 1995; Rhoads and Friedberg, 1997). The IQ domains regulate the functions of most of the myosin classes studied (Uyeda et al., 1996; Zhu et al., 1996; Zhu et al., 1998; Purcell et al., 2002; Schott et al., 2002; Moore et al., 2004; Sakamoto et al., 2005). The lever arm hypothesis (for review, Spudich, 1994) postulates that for all myosins, small movements of the head domain are amplified by the myosin neck regions to longer distances traveled along the actin molecules in the cell. This hypothesis is supported in the case of the conventional myosin or Myosin-II (MyoII). As the length of the neck domain of MyoII was shortened by successively deleting the regulatory domains in the protein, the velocity of its movement became slower (Uyeda et al., 1996). In contrast, addition of regulatory domains resulted in a faster moving MyoII compared to the wild type protein (Uyeda et al., 1996). This relationship between the neck length and velocity of myosins is also defined by the mathematical equation $v=\mathrm{d} / \mathrm{t}_{\mathrm{on}}$ (Huxley, 1990; Uyeda et al., 1996; Moore et al., 2004; Lin et al., 2005) where $v$ is the velocity, $d$ is the step size of the myosin along F-actin, and $\mathrm{t}_{\text {on }}$ is the time myosin is strongly bound to F- 
actin (Uyeda et al., 1996; Lin et al., 2005). Assuming $t_{\text {on }}$ to be constant, velocity is directly proportional to the step size that in turn is dependent on the lever arm length.

The unconventional myosin Myolb consists of several alternatively spliced isoforms that have varying numbers of IQ motifs (Ruppert et al., 1993; Lin et al., 2005). Biochemical characterization of these proteins revealed differential $\mathrm{CaM}$ binding affinities of the IQ domains among splice variants (Lin et al., 2005). While such differences did not cause a change in ATPase rate of Myolb isoforms, it was reported that the motility increased with more CaMs bound to Myolb (Lin et al., 2005). Thus the IQ domain is predicted to act as a lever arm for this myosin as well.

However this may not be the case in all unconventional myosins. Testing the lever arm hypothesis in Myosin V has been controversial. MyoV is a two-headed unconventional myosin (Cheney et al., 1993) consisting of one motor domain in each of the two heads and a large neck region consisting of six IQ motifs (Cheney et al., 1993). Laser trap studies using purified wild type and mutated MyoV with truncated IQ domains demonstrated similar step sizes along F-actin molecules (Tanaka et al., 2002). It was hypothesized that the neck of this myosin did not function as a lever region, instead the head domain was responsible for the large step sizes associated with the truncated molecules (Tanaka et al., 2002). Several other groups investigating the cell biological or biophysical properties of this myosin maintain that the neck domain of MyoV acts as an amplifier of the movements of the motor domains (Purcell et al., 2002; Schott et al., 2002; Moore et al., 2004; Sakamoto et al., 2005). In yeast, the movement of secretory 
vesicles is dependent on the presence of MyoV (Schott et al., 1999). Expression of mutant proteins lacking either two or four IQ domains showed reduced velocity of movement compared to the wild type or the mutant expressing eight IQ motifs (Schott et al., 2002). Subsequent studies with purified proteins using chicken MyoV or the murine isoform demonstrated the importance of the neck length in the step size of this myosin as well (Purcell et al., 2002; Moore et al., 2004; Sakamoto et al., 2005)

The importance of the lever arm in force production has not been investigated for Myo1c, although the CaM molecules have been clearly shown to confer rigidity on this myosin molecule (Zhu et al., 1996; Zhu et al., 1998). To further understand this regulation, the length of the neck region of Myolc was altered by generating truncated forms of the protein as outlined in the methods section. These truncated constructs, along with the wild-type Myo1c were used to generate recombinant baculoviruses that were subsequently used to infect $\mathrm{Sf} 9$ insect cells to produce wild type and truncated proteins.

\section{Materials and Methods}

\section{Generation of truncated constructs of Myo1c containing the head, tail and each} successively lacking IQ domains 4, 3 and 2: The truncated forms of Myo1c (Fig. 1 \& 4) were generated using high-fidelity polymerase chain reaction (PCR) with Pfu polymerase (Invitrogen, Carlsbad, CA) and PCR sewing techniques (Horton et al., 1989; Fig. 2) with the frog full-length Myo1c cDNA as the template. Due to lack of suitable restriction sites between the neck and tail regions of Myolc, PCR sewing allowed us to join the two regions without the use of restriction endonucleases. The annealing temperatures 
employed for each set of primers varied between $55^{\circ} \mathrm{C}-75^{\circ} \mathrm{C}$ as indicted in Table 1 and the inserts were amplified 1 minute for every kilobase pair for a total of 30 cycles. The steps in this reaction are briefly:

(1) The individual pieces (head-neck and tail) were amplified using high fidelity PCR and purified using PCR purification columns (Qiagen, Valencia, CA). The primers (Table 1) to the neck and tail regions have sequences that are complementary to the tail or the neck respectively (Fig. 3).

(2) The PCR products were analyzed on a gel (Fig. 4), purified by gel extraction and combined in a molar ratio of 1:1 for a second PCR reaction without added primers, to get one contiguous piece of "sewn" DNA.

(3) The sewn piece of DNA from step 2 acted as a template for an additional PCR reaction to obtain enough DNA for transforming bacterial cells. The DNA from this step and the pFastBac HTA plasmid (Invitrogen) are subjected to restriction enzyme digestion using restriction enzymes Bam H1 and Spe1 (New England Biolabs, Ipswich, MA). The plasmid is treated with calf intestinal phosphatase (New England Biolabs) to prevent reclosure of the DNA during ligation. The plasmid and the inserts were purified by gel extraction and ligated using T4 DNA ligase (New England Biolabs). The ligated plasmid was used to transform DH5 $\alpha$ cells (Invitrogen) according to the manufacturer's protocol. The constructs contain a $\mathrm{His}_{6}$ tag and an Xpress-tag at the N-terminus and were sequenced in their entirety to screen for any mutations in the open reading frame. Purified plasmids were used to obtain recombinant baculoviruses. Recombinant 
baculoviruses expressing CaM were co-infected along with Myolc for protein expression in Sf9 insect cells.

In addition, a second set of constructs were made that have a c-myc tag (Sundaresan et al., 1987) (amino acid sequence-EQKLISEEDL) after the tail domain (Fig.1). These constructs will enable us to use commercially available antibodies against c-myc for future in vitro motility assays. The c-myc constructs were generated as follows:

(1) A c-myc cassette was generated with the use of $5^{\prime}$ phosphorylated primers complementary to the c-myc sequence (Table 1 \& Fig. 3), also consisting of overhangs of the restriction sites for the enzymes Kpn 1 and Spe 1 as color coded in Table 1. Briefly, the two phosphorylated primers were incubated together at $94^{\circ} \mathrm{C}$ for 2 minutes, $37^{\circ} \mathrm{C}$ for 5 minutes and room temperature thereafter. This cassette was then ligated using T4 DNA ligase to the pFastBac plasmid digested with restriction enzymes Kpn1 and Spe1 (Table 1; New England Biolabs) and the plasmid was used to transform DH5 $\alpha$ cells using the manufacturer's protocol.

(2) The head-neck-tail region generated by PCR is ligated to the c-myc-plasmid, by the use of suitable restriction enzymes (Table 1). The constructs were sequenced in their entirety to ensure preservation of the reading frame and expressed as previously outlined.

Protein purification: The recombinant frog Myolc proteins, both wild type (baculovirus stock received from Dr. Peter Gillespie, OHSU) and truncated, were purified as described previously (Gillespie et al., 1999). Briefly, Sf9 cells infected with wild type Myolc and 
$\mathrm{CaM}$ viruses were sedimented and the cell pellets were resuspended in the lysis buffer containing $25 \mathrm{mM}$ Tris $\mathrm{pH} \quad 8, \quad 0.5 \mathrm{mM} \quad \mathrm{MgCl}_{2}, \quad 0.5 \mathrm{mM} \quad$ EGTA, $2.5 \mathrm{mM} \quad 2-$ mercaptoethanol, $0.2 \mu \mathrm{M}$ PMSF, $1 \mu \mathrm{M}$ leupeptin, and $1 \mu \mathrm{M}$ pepstatin, and lysed by passing twice each through 22-g and 25-g needles using a 10-ml luer lock syringe. The lysate was adjusted to final $\mathrm{NaCl}$ and ATP concentrations of $400 \mathrm{mM}$ and $1 \mathrm{mM}$ respectively and centrifuged at $\sim 400,000 \mathrm{~g}$ for 30 minutes at $4^{\circ} \mathrm{C}$ to sediment cellular debris. The supernatant containing the soluble protein was passed through a Nickel nitriloacetic acid $\left(\mathrm{Ni}^{2+}{ }^{2} \mathrm{NTA}\right)$ affinity column (Qiagen, $\left.\mathrm{CA}\right)$ at $4{ }^{\circ} \mathrm{C}$. His $\sigma_{-}$-tagged proteins were retained on the column bound to the $\mathrm{Ni}^{2+}$ and the other proteins were discarded as they flow through the column. The column was washed with wash buffer containing $300 \mathrm{mM} \mathrm{NaCl}, 25 \mathrm{mM}$ Tris $\mathrm{pH} 8,0.5 \mathrm{mM} \mathrm{MgCl}_{2}, 0.5 \mathrm{mM}$ EGTA, $2.5 \mathrm{mM} \mathrm{2-}$ mercaptoethanol, $0.2 \mu \mathrm{M}$ PMSF, $1 \mu \mathrm{M}$ leupeptin, and $1 \mu \mathrm{M}$ pepstatin to discard nonspecifically bound proteins. The bound proteins were eluted with an elution buffer containing $125 \mathrm{mM}$ imidazole $\mathrm{pH} 8,200 \mathrm{mM} \mathrm{KCl}, 15 \mathrm{mM}$ HEPES $\mathrm{pH} 8,1 \mathrm{mM} \mathrm{MgCl}_{2}$, $0.1 \mathrm{mM}$ EGTA, $2.5 \mathrm{mM}$ 2-mercaptoethanol, $0.2 \mu \mathrm{M}$ PMSF, $1 \mu \mathrm{M}$ leupeptin, and $1 \mu \mathrm{M}$ pepstatin, which replaced the protein with the imidazole on the column. Several fractions were eluted and protein concentration was assayed using Bradford reagent (Bradford, 1976) using BSA as a standard. Fractions with the highest concentration of protein were combined together. Gel-filtration chromatography was used to check for aggregation of a part of the protein, using $25 \mathrm{ml}$ Superdex 200HR 10/300 column with an AKTA/FPLC system (Amersham, NJ) in a buffer consisting of $15 \mathrm{mM}$ HEPES, $400 \mathrm{mM} \mathrm{KCl}, 1 \mathrm{mM}$ $\mathrm{MgCl}_{2}, 1 \mathrm{mM}$ EGTA, based on the elution profile at $\mathrm{A}_{280}$. 
Actin purification from rabbit muscle acetone powder: The wild type and the truncated Myolc proteins were used in ATPase assays as outlined in chapter III. These assays require purified F-actin protein. Actin was purified from rabbit muscle acetone powder (Pel Freez, Rogers, AR) according to the protocol of Pardee and Spudich (1982) with modifications. Briefly, the acetone powder was dissolved in buffer A containing 2 $\mathrm{mM}$ Tris $\mathrm{pH}$ 8, $0.2 \mathrm{mM}$ ATP $\mathrm{pH} 7,0.5 \mathrm{mM}$ DTT, $0.1 \mathrm{mM} \mathrm{CaCl}_{2}$ and $1 \mathrm{mM}$ sodium azide and subjected to high speed centrifugation at $300,000 \mathrm{~g}$ for 20 minutes to separate non-actin binding proteins in the preparation. The actin present in the supernatant was polymerized by the addition of $\mathrm{KCl}$ to a final concentration of $800 \mathrm{mM}$ and $2 \mathrm{mM} \mathrm{MgCl} 2$ centrifuged at $400,000 \mathrm{~g}$ for 30 minutes at $4^{\circ} \mathrm{C}$ to sediment the F-actin. This actin was depolymerized by dialyzing into buffer $\mathrm{A}$ devoid of $\mathrm{KCl}$ and $\mathrm{MgCl}_{2}$ at $4{ }^{\circ} \mathrm{C}$ over a period of 2 days. The G-actin thus formed was centrifuged at $400,000 \mathrm{~g}$ for 30 minutes to sediment co-purifying proteins, polymerized with the addition of $50 \mathrm{mM} \mathrm{KCl}$ and $1 \mathrm{mM} \mathrm{MgCl}$ and dialyzed into the ATPase buffer containing $15 \mathrm{mM} \mathrm{HEPES} \mathrm{pH} \mathrm{7.5,}$ $50 \mathrm{mM} \mathrm{KCl}, 1 \mathrm{mM} \mathrm{MgCl} 2$ and $1 \mathrm{mM}$ sodium azide. The dialyzed protein was sedimented at $400,000 \mathrm{~g}$ for 30 minutes at $4^{\circ} \mathrm{C}$ and resuspended in ATPase buffer and stored up to 2-3 weeks at $4^{\circ} \mathrm{C}$.

Actin cycling of the purified protein to assay the amount of functional Myo1c: A portion of the Myolc protein was further subjected to a second step of purification following elution from the $\mathrm{Ni}^{+2}$-NTA column to assess the percentage of functionally active enzyme molecules in the preparation. The purified protein was incubated with $10 \mu \mathrm{M}$ F-actin stabilized with $15 \mu \mathrm{M}$ unlabeled phalloidin (Invitrogen) on ice for 30 
minutes, followed by centrifugation at $400,000 \mathrm{~g}$ for 30 minutes at $4^{\circ} \mathrm{C}$. The F-actin pellet containing any bound Myolc was resuspended in a buffer containing 15 mM HEPES pH 7.5, $50 \mathrm{mM} \mathrm{KCl}, 1 \mathrm{mM} \mathrm{MgCl} 2,0.1 \mathrm{mM}$ EGTA, $2.5 \mathrm{mM}$ 2-mercaptoethanol, $0.2 \mu \mathrm{M}$ PMSF, $1 \mu \mathrm{M}$ leupeptin, and $1 \mu \mathrm{M}$ pepstatin, $0.3 \%$ Tween-20 and $5 \mathrm{mM}$ ATP. This step removed enzymatically dead Myo1c that was not released by the ATP and remains bound to F-actin and was discarded (Gillespie et al., 1999). The solution was centrifuged at $400,000 \mathrm{~g}$ for 30 minutes at $4^{\circ} \mathrm{C}$ and the supernatant consisted of the enzymatically active Myo1c protein. Actin-cycling and subsequent release by ATP ensured that the recovered protein preparation was enzymatically active (Gillespie et al., 1999).

Analysis of protein purity: The proteins were run on 12\% SDS polyacrylamide gels and stained with colloidal blue (Invitrogen). Gels were destained and scanned using Personal Densitometer SI (Molecular Dynamics, Sunnyvale, CA) equipped with ImageQuant software (v5.2; Molecular Dynamics). As well, densitometry was performed on scanned gels to compare the percentage of Myolc that bound and released from F-actin after resuspension in an ATP-containing buffer with the Myolc eluted from the $\mathrm{Ni}^{2+}$-NTA column. Thus the protein concentration of the $\mathrm{Ni}^{2+}-\mathrm{NTA}$ elute obtained by Bradford reagent was normalized for percentage purity and percentage of active Myo1c. This normalized Myo1c protein concentration was used in all subsequent assays performed with the purified proteins. Details on the analysis of purity and determination of functional Myolc are discussed in the appendix. 
Western blot analysis: Protein samples were run on a $12 \%$ SDS-PAGE gel in trisglycine buffer and transferred overnight onto Immobilon PVDF membrane (Millipore, Bedford, MA). The membranes were blocked with 5\% nonfat dry milk in Tris-buffered saline-Tween 20 (TBS-T; 1.5M NaCl, 0.5 M Trizma base, 0.1\% Tween-20, $\mathrm{pH} 8.0$ ) for 1 hour at RT. Primary antibody (anti-Xpress, Invitrogen) was added at a 1:2500 dilution in 5\% nonfat dry milk in TBS-T for 1 hour. Membranes were washed 3X10 minutes in TBS-T and incubated with goat anti-mouse secondary antibody conjugated to horseradish peroxidase at a 1:20,000 dilution (Jackson Laboratoreies Inc, West Grove, PA) for 1 hour at RT. The proteins were detected by ECL plus Western Blotting Detection system (GE Healthcare, Piscataway, NJ). 
Table 1: Primer sequences for amplification of truncated Myo1c proteins

\begin{tabular}{|c|c|c|c|}
\hline \# & Primer name & $\begin{array}{l}\text { Sequence } 5 '-3 ' \\
\text { (Overhangs) }\end{array}$ & $\begin{array}{l}\text { Melting } \\
\text { temperature } \\
\text { used }\left({ }^{\circ} \mathrm{C}\right)\end{array}$ \\
\hline 1 & HeadFwdBamH1 & TAACGGATCCAGGTATGGCTAGCATGACTGGTGGA & 74 \\
\hline 2 & TailRevSTOPSpe1 & CATGACTAGTTCATCGTGAATTCAGACGAGGAGC & 72 \\
\hline 3 & IQ2RevTail & CAGGACTTGTCCAGCACACTTGCAGCTTTTCGTCTGCC & 50 \\
\hline 4 & TailFwdIQ2 & GGCAGACGAAAAGCTGCAAGTGTGCTGGACAAGTCCTG & 50 \\
\hline 5 & IQ3RevTail & CAGGACTTGTCCAGCACACTACGGGGTTGATTGCGGTA & 50 \\
\hline 6 & TailFwdIQ3 & ATTTACCGCAATCAACCCCGTAGTGTGCTGGACAAGTCC & 50 \\
\hline 7 & IQ1RevTail & GGACTTGTCCAGCACACTCAGGAATTTCTGTCGTTGATG & 60 \\
\hline 8 & TailFwdIQ1 & CAACGACAGAAATTCCTGAGTGTGCTGGACAAGTCC & 50 \\
\hline \multirow[t]{2}{*}{9} & Spe1c-mycKpn1 & $\begin{array}{l}\mathrm{P}^{-} \text {-CTAGTGAGCAGAAGCTGATCAGCGAGGAAGACCTGTGAGGA } \\
\text { TC }\end{array}$ & 55 \\
\hline & & $\mathrm{P}^{-}$-CTCACAGGTCTTCCTCGCTGATCAGCTTCTGCTCA & \\
\hline
\end{tabular}




\section{Results and Discussion}

Analysis of protein purity: To obtain purified Myo1c protein from Sf9 insect cells we employed affinity chromatography using $\mathrm{Ni}^{2+}$-NTA agarose beads (Qiagen, CA). Myolc has a $\mathrm{His}_{6}$ tag at the $\mathrm{N}$-terminus that binds to the $\mathrm{Ni}^{2+}$ in the affinity column, thus enabling selective purification of the protein over other proteins in the insect cell homogenate. The purified Myolc as shown in Fig. 5 co-purified with a number of other contaminating proteins. As a result, determination of protein concentration by Bradford assay is not reflective of solely Myo1c in the preparation. To account for this, we have determined the percentage of purity of our protein of interest compared to other nonspecific proteins. CaM co-purifies with Myolc, hence the CaM molecules were included in determination of protein purity of the sample. In addition, the percentage of functional enzyme in the protein preparation was estimated based on the amount of Myolc that bound and released F-actin in the presence of ATP. It is evident from our results that a substantial fraction of the purified protein was not enzymatically active. It has also been reported previously that for the rat Myo1c isoform, about 50\% of the protein that bound F-actin released in the presence of ATP (Gillespie et al., 1999). Our analyses suggest that nearly $12 \%$ of the frog enzyme was active, which is lower than that reported for the rat isoform. This could be because the frog isoform is less stable and the protein loses activity faster than other isoforms. Another possibility is that the protein expression in Sf9 insect cells is low resulting in decreased yield of functional protein.

Purification of mutated Myo1c constructs: To determine the effect of truncation of Myo1c neck domains on its function, we generated several constructs successively 
lacking IQ domains 4, 3 and 2. As well, other constructs were generated by mutating key residues in the IQ domains responsible for binding CaM. One of these is FL2 consisting of the mutation IQ $\rightarrow$ AA in the $2^{\text {nd }}$ IQ domain of Myolc (K.R. Phillips, unpublished data). All of these mutated proteins have a $\mathrm{His}_{6}$ tag at the $\mathrm{N}$-terminus for protein purification by $\mathrm{Ni}^{2+}$-NTA affinity chromatography, similar to the wild type protein. The truncated proteins HIQ12T (Fig. 1; Row B; left) and FL2 were purified as outlined in the methods section and run on 12\% SDS-PAGE. Both HIQ12T and FL2 had low expression in the insect cell culture systems and we were unable to definitively identify the myosin protein on the stained gel. To examine if the proteins were being expressed at all, we performed immunoblots on the high speed supernatant, flow through and the $\mathrm{Ni}^{2+}$-NTA elute of the HIQ12T and FL2 proteins. As indicated in Fig. 6, HIQ12T and FL2 could only be detected in the elutes at very low levels. It is possible that the proteins are being expressed at very low levels in the insect cells and require further optimization of expression for each construct. 


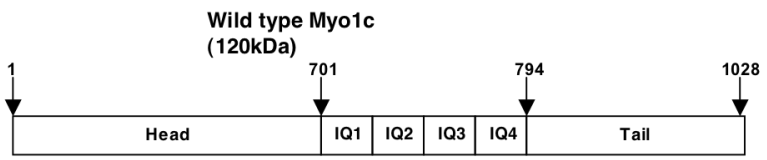

\begin{tabular}{|l|r|r|r|c|}
\hline H HIQ123T ( 113kDa) \\
\hline Head & 101 & 102 & 103 & Tail \\
\hline
\end{tabular}

B

\begin{tabular}{|l|l|l|l|}
\hline \multicolumn{4}{|c|}{ HIQ12T $(\sim 110 \mathrm{kDa})$} \\
\hline Head & IQ1 & IQ2 & Tail \\
\hline
\end{tabular}

C HIQ1T ( 108kDa)

\begin{tabular}{|l|l|l|}
\hline \multicolumn{3}{|c|}{ HIQ1T $(\sim 108 \mathrm{kDa})$} \\
\hline Head & IQ1 & Tail \\
\hline
\end{tabular}

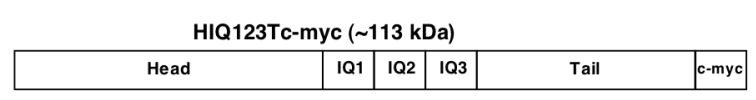

HIQ12Tc-myc ( 110kDa)

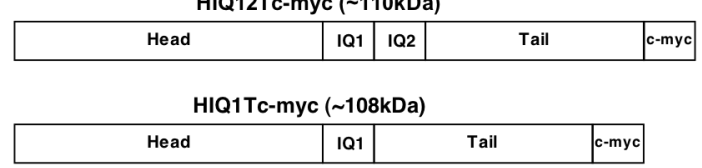

D

FL2 (120 kDa)
\begin{tabular}{|c|c|c|c|c|c|}
\hline Head & IQ1 & IQ2 & IQ3 & IQ4 & Tail \\
\hline \\
\\
$\qquad$ \\
\hline
\end{tabular}

Figure. 1. Deletion constructs of Myo1c. The wild-type construct is shown at the top. The numbers indicate the positions of the amino acids in the protein. Approximate molecular weights are indicated in parentheses. Each of the constructs has a $\mathrm{His}_{6}$-tag for purification and a Xpress tag at the $\mathrm{N}$-terminus for detection. The constructs in rows $A, B$ and $C$ lack IQ domains 4,3 or 2. Each of the constructs in the left panel has a c-myc tag after the tail for immobilization. Construct in row $D$ has mutation in the $2^{\text {nd }}$ IQ domain (isoluecine/glutamine to alanine residues). Diagram is not drawn to scale. 
Wild type construct

\begin{tabular}{|c|c|c|c|c|c|}
\hline Head & IQ1 & IQ2 & IQ3 & IQ4 & Tail \\
\hline
\end{tabular}

Step 1: Amplification of the head up to IQ2. Add primers complementary to head ( $R S 5^{\prime}$ ) and IQ2 (with overhangs complementary to 5 ' region of tail as color coded)

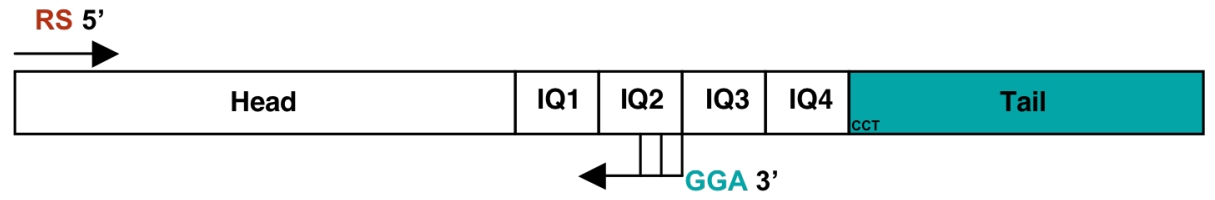

Step 2: Amplification of the tail. Add primers complementary to 3' end of tail (3'RS) and $5^{\prime}$ end of tail (with overhangs complementary to $3^{\prime}$ end of IQ2 as color coded)

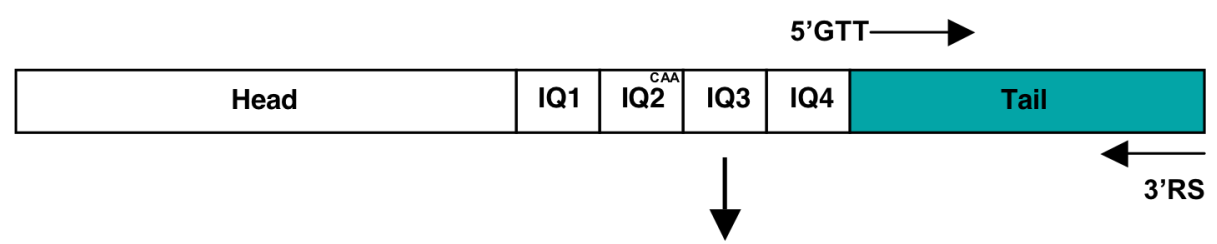

Step 3: PCR sewing: The overhangs on each insert can act as primers in the subsequent PCR reaction 5'RS

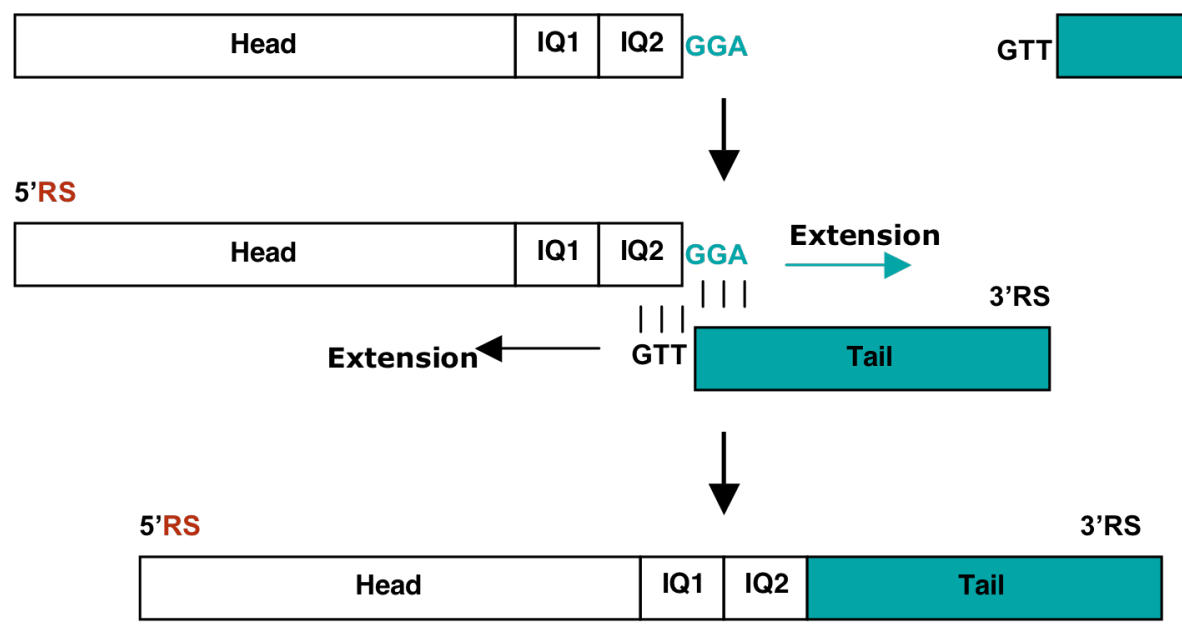

Figure 2. Outline of PCR sewing technique. The two DNA strands are amplified in separate reactions with primers that have sequences complementary to the other strand as shown in step 1. RS, restriction site. In step 2 the two amplified fragments with overhangs at 5 ' and 3 ' ends are combined in another PCR reaction without added primers. This results in the joining of the two fragments as one contiguous piece of DNA. In the last step this DNA strand is amplified with the 5' primer of the head and the 3' primer of the tail from the very first step. Diagram is not drawn to scale. 
5' CAT CAC CAT CAC CAT CAC GAT TAC GAT ATC CCA ACG ACC GAA AAC

$\begin{array}{lllllllllllllll}\mathbf{H} & \mathbf{H} & \mathbf{H} & \mathbf{H} & \mathbf{H} & \mathbf{H} & \mathrm{D} & \mathrm{Y} & \mathrm{D} & \mathrm{I} & \mathrm{P} & \mathrm{T} & \mathrm{T} & \mathrm{E} & \mathrm{N}\end{array}$ CTG TAT TTT CAG GGC GCC ATG GAT CCA GGT ATG GCT AGC ATG ACT $\begin{array}{lllllllllllllll}L & Y & F & Q & G & A & M & D & P & G & M & A & S & M & T\end{array}$ GGT GGA CAG CAA ATG GGT CGG GAT CTG TAC GAC GAT GAC GAT AAG $\begin{array}{lllllllllllllll}G & G & Q & Q & M & G & R & D & L & Y & D & D & D & D & K\end{array}$ GAT TCC ATG GAg AGT GCC TTA ACA GCC CGA GAT CGG GTT GGT GTC $\begin{array}{lllllllllllllll}\mathrm{D} & \mathrm{S} & \mathrm{M} & \mathrm{E} & \mathrm{S} & \mathrm{A} & \mathrm{L} & \mathrm{T} & \mathrm{A} & \mathrm{R} & \mathrm{D} & \mathrm{R} & \mathrm{V} & \mathrm{G} & \mathrm{V}\end{array}$ CAG GAC TTT GTC CTG CTG GAA AAC TAC ACC AGT GAA GCT GCA TTT $\begin{array}{lllllllllllllll}Q & D & F & V & L & L & E & N & Y & T & S & E & A & A & F\end{array}$ ATA GAA AAC CTG AGg AAg CGA TTT AAA GAA AAT CTC ATA TAT ACG $\begin{array}{lllllllllllllll}I & E & N & L & R & K & R & F & K & E & N & L & I & Y & T\end{array}$ TAC ATT GGG TCA GTC TTG GTA TCT GTC AAT CCT TAC AAA GAG TTA $\begin{array}{llllllllllllllll}Y & I & G & S & V & L & V & S & V & N & P & Y & K & E & L\end{array}$ GAG ATT TAC AGC AAG CAA CAC ATG GAG AGA TAT CGT GGA GTT AGT $\begin{array}{lllllllllllllll}E & I & Y & S & K & Q & H & M & E & R & Y & R & G & V & S\end{array}$ TTC TAT GAA GTG TCT CCT CAT ATA TAT GCC ATA GCA GAT AAC TCC $\begin{array}{lllllllllllllll}\mathrm{F} & \mathrm{Y} & \mathrm{E} & \mathrm{V} & \mathrm{S} & \mathrm{P} & \mathrm{H} & \mathrm{I} & \mathrm{Y} & \mathrm{A} & \mathrm{I} & \mathrm{A} & \mathrm{D} & \mathrm{N} & \mathrm{S}\end{array}$ TAC CGC TCC TTG CGC ACA GAg AgG AAA GAC CAg TGT ATT CTT AtA $\begin{array}{lllllllllllllll}Y & R & S & L & R & T & E & R & K & D & Q & C & I & L & I\end{array}$ TCT GGT GAG AGT GGG GCT GGG AAG ACT GAG GCC AGC AAG AAA ATC $\begin{array}{llllllllllllllll}S & G & E & S & G & A & G & K & T & E & A & S & K & K & I\end{array}$ CTA CAG TAC TAT GCT GTG ACG TGT CCT GTC AGT GAC CAG GTG GAG $\begin{array}{llllllllllllllllllllllll}\mathrm{L} & \mathrm{Q} & \mathrm{Y} & \mathrm{Y} & \mathrm{A} & \mathrm{V} & \mathrm{T} & \mathrm{C} & \mathrm{P} & \mathrm{V} & \mathrm{S} & \mathrm{D} & \mathrm{Q} & \mathrm{V} & \mathrm{E}\end{array}$ ACT GTG AAA GAC CGA CTT CTG CAG TCC AAT CCT GTT TTG GAg GCA $\begin{array}{lllllllllllllllllllllll}T & V & K & D & R & L & L & Q & S & N & P & V & L & E & A\end{array}$ TTT GGC AAT GCA AAA ACC TTA CGA AAT GAT AAT TCC AGC CGC TTC $\begin{array}{llllllllllllllll} & \mathrm{G} & \mathrm{N} & \mathrm{A} & \mathrm{K} & \mathrm{T} & \mathrm{L} & \mathrm{R} & \mathrm{N} & \mathrm{D} & \mathrm{N} & \mathrm{S} & \mathrm{S} & \mathrm{R} & \mathrm{F}\end{array}$ GGA AAA TAT ATG GAT GTG CAA TTT GAT TAC AAG GGA GCT CCT GTC $\begin{array}{llllllllllllllll}G & K & Y & M & D & V & Q & F & D & Y & K & G & A & P & V\end{array}$ Ggt GGA CAT ATt tTA AAC TAT CTC TTG GAA AAg TCC CGT GTG GTA $\begin{array}{llllllllllllllll}G & G & H & I & L & N & Y & L & L & E & K & S & R & V & \text { V }\end{array}$ CAT CAG AAC CAC GGA GAg AgA AAC tTC CAT ATt tTT tAC CAg CTT $\begin{array}{lllllllllllllll}\mathrm{H} & \mathrm{Q} & \mathrm{N} & \mathrm{H} & \mathrm{G} & \mathrm{E} & \mathrm{R} & \mathrm{N} & \mathrm{F} & \mathrm{H} & \mathrm{I} & \mathrm{F} & \mathrm{Y} & \mathrm{Q} & \mathrm{L}\end{array}$ CTT GAG GGT GGA GAA GAg GAT TTG CTA CGG AGg CTG GGg CTG GAT $\begin{array}{lllllllllllllll}L & E & G & G & E & E & D & L & L & R & R & L & G & L & D\end{array}$ AAA AAT GCC CAA AAT TAC CAG TAC TTG ATT AAG GGT CAG TGT GCC $\begin{array}{lllllllllllllllllllll}K & N & A & Q & N & Y & Q & Y & L & I & K & G & Q & C & A\end{array}$ AGg GTT AGC TCA ATC AAT GAT AAA AAT GAC TGG AAG GTT GTT AGG $\begin{array}{lllllllllllllll}R & \mathrm{~V} & \mathrm{~S} & \mathrm{~S} & \mathrm{I} & \mathrm{N} & \mathrm{D} & \mathrm{K} & \mathrm{N} & \mathrm{D} & \mathrm{W} & \mathrm{K} & \mathrm{V} & \mathrm{V} & \mathrm{R}\end{array}$ CGA GCC TTG tCA ATt AtA AAC tTC AAT GAT GAT GAt AtA GAg GAA $\begin{array}{lllllllllllllll}R & A & L & S & I & I & N & F & N & D & D & D & I & E & E\end{array}$ TTG CTG AGC ATT GTT GCT AGT GTA CTA CAT TTG GGA AAT GTG CAG $\begin{array}{llllllllllllllll}L & L & S & I & V & A & S & V & L & H & L & G & N & V & Q\end{array}$ TTT GCC ACA GAT GAG CAT GGA CAT GCC CAA GTC ACA ACA GAA AAC $\begin{array}{llllllllllllllll}F & A & T & D & E & H & G & H & A & Q & V & T & T & E & N\end{array}$ CAG ATT AAA TAC CTC GCC AGG CTC CTC TCT GTA GAC TCT ACT GTA

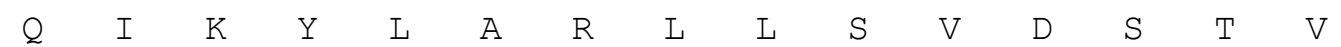
CTA CGg GAg tCt CtC AtT CAC AAA AAg AtT Att gCt AAA GgA GAA $\begin{array}{lllllllllllllll}\mathrm{L} & \mathrm{R} & \mathrm{E} & \mathrm{S} & \mathrm{L} & \mathrm{I} & \mathrm{H} & \mathrm{K} & \mathrm{K} & \mathrm{I} & \mathrm{I} & \mathrm{A} & \mathrm{K} & \mathrm{G} & \mathrm{E}\end{array}$ 
GAG CTG AAC AGT CCA CTT AAC CTG GAg CAA GCT GCT TAT GCT CGA $\begin{array}{lllllllllllllll}E & \mathrm{~L} & \mathrm{~N} & \mathrm{~S} & \mathrm{P} & \mathrm{L} & \mathrm{N} & \mathrm{L} & \mathrm{E} & \mathrm{Q} & \mathrm{A} & \mathrm{A} & \mathrm{Y} & \mathrm{A} & \mathrm{R}\end{array}$ GAT GCC TTG GCC AAA GCA ATC TAT GGC CGT ACC TTC TCC TGG CTT $\begin{array}{lllllllllllllll}D & A & L & A & K & A & I & Y & G & R & T & F & S & W & L\end{array}$ GTT AGC AAG ATT AAC AAA TCT CTG GCA TAC AAg GGT ACA GAT ATG $\begin{array}{lllllllllllllll}V & S & K & I & N & K & S & L & A & Y & K & G & T & D & M\end{array}$ CAC AAg CTT GGg AGC GCA TCT GTC AtA GGA CTT TTG GAC ATA tAT $\begin{array}{lllllllllllllll}H & K & L & G & S & A & S & V & I & G & L & L & D & I & Y\end{array}$ GGT TTT GAA GTT TTT CAA CAT AAC AGC TTC GAA CAA TTT TGC ATT $\begin{array}{lllllllllllllllllllll}G & F & E & V & F & Q & H & N & S & F & E & Q & F & C & I\end{array}$ AAT tTT tGC AAT GAA AAA CTG CAg CAg tTG tTT AtA GAg Ctg ACG $\begin{array}{lllllllllllllll}N & F & C & N & E & K & L & Q & Q & L & F & I & E & L & T\end{array}$ TTG AAG TCT GAG CAG GAT GAA TAT GAA TCT GAA GGG ATT GCA TGG $\begin{array}{lllllllllllllll}L & K & S & E & Q & D & E & Y & E & S & E & G & I & A & W\end{array}$ GAG CCA GTC CAG TAT TTT AAT AAC AAA ATA ATC TGC GAT CTG GTC $\begin{array}{llllllllllllllll}E & P & V & Q & Y & F & N & N & K & I & I & C & D & L & V\end{array}$ GAA GAG AAA TTC AAA GGC ATC ATT TCC ATT CTG GAT GAA GAA TGT $\begin{array}{lllllllllllllll}E & E & K & F & K & G & I & I & S & I & L & D & E & E & C\end{array}$ TTA CGT CCA GGA GAA GCC ACA GAT ATG ACA TTC CTG GAG AAg TTG $\begin{array}{llllllllllllllllllllllllll}L & R & P & G & E & A & T & D & M & T & F & L & E & K & L\end{array}$ GAG GAC ACT GTG AAA AAC CAC CCA CAC TTT GTG ACA CAC AAA CTT $\begin{array}{lllllllllllllllllllllll}E & D & T & V & K & N & H & P & H & F & V & T & H & K & L\end{array}$ GGA GAC CAG AAA ACC CGA AAA GTG CTT GGC AGA GAT GAA TTC CGT $\begin{array}{lllllllllllllll}G & D & Q & K & T & R & K & V & L & G & R & D & E & F & R\end{array}$ TTG CTG CAT TAT GCT GGG GAA GTG AAC TAC AGT GTA GCA GGG TTC $\begin{array}{lllllllllllllllllllllll}\mathrm{L} & \mathrm{L} & \mathrm{H} & \mathrm{Y} & \mathrm{A} & \mathrm{G} & \mathrm{E} & \mathrm{V} & \mathrm{N} & \mathrm{Y} & \mathrm{S} & \mathrm{V} & \mathrm{A} & \mathrm{G} & \mathrm{F}\end{array}$ CTT GAT AAA AAC AAT GAT CTG CTG TTT CGC AAT CTG AAG GAg GTA $\begin{array}{llllllllllllllll}\mathrm{L} & \mathrm{D} & \mathrm{K} & \mathrm{N} & \mathrm{N} & \mathrm{D} & \mathrm{L} & \mathrm{L} & \mathrm{F} & \mathrm{R} & \mathrm{N} & \mathrm{L} & \mathrm{K} & \mathrm{E} & \mathrm{V}\end{array}$ ATG TGC GAC TCT GGA AAC CCG ATt GCA CAT CAG TGT TTT AAT CGG $\begin{array}{llllllllllllllll}M & C & D & S & G & N & P & I & A & H & Q & C & F & N & R\end{array}$ TCT GAA CTG ACG GAC AAG AAA AGg CCA GAG ACG GCA GCA ACA CAG $\begin{array}{lllllllllllllll}\mathrm{S} & \mathrm{E} & \mathrm{L} & \mathrm{T} & \mathrm{D} & \mathrm{K} & \mathrm{K} & \mathrm{R} & \mathrm{P} & \mathrm{E} & \mathrm{T} & \mathrm{A} & \mathrm{A} & \mathrm{T} & \mathrm{Q}\end{array}$ TTT AAA AAT AGC CTC TCA AAg CTG ATG GAA ATT CTT ATG tCC AAg $\begin{array}{lllllllllllllll}F & K & N & S & L & S & K & L & M & E & I & L & M & S & K\end{array}$ CAG CCT TCA TAC GTA CGG TGC ATA AAG CCC AAT GAT GCC AAA CAA $\begin{array}{lllllllllllllll}\mathrm{Q} & \mathrm{P} & \mathrm{S} & \mathrm{Y} & \mathrm{V} & \mathrm{R} & \mathrm{C} & \mathrm{I} & \mathrm{K} & \mathrm{P} & \mathrm{N} & \mathrm{D} & \mathrm{A} & \mathrm{K} & \mathrm{Q}\end{array}$ CCA GCT CGT TTT GAT GAA GTG CTG ATC AGA CAC CAG GTG AAA TAT $\begin{array}{llllllllllllllll}P & A & R & F & D & E & V & L & I & R & H & Q & V & K & Y\end{array}$ CTG GGA CTT ATT GAA AAT GTG CGC GTA CGC CGA GCT GGA TTT GCA $\begin{array}{lllllllllllllllllllllllll}L & G & L & I & E & N & V & R & V & R & R & A & G & F & A\end{array}$ TAT AgG CGA AAA TAT GAg ATC TTC TTA CAA AgG TAC AAA TCT CTT $\begin{array}{lllllllllllllll}Y & R & R & K & Y & E & I & F & L & Q & R & Y & K & S & L\end{array}$ TGC CCT GAT ACT TGG CCT AAC TGG GAT GGC CGT GCA ATG GAT GGT $\begin{array}{lllllllllllllll}C & P & D & T & W & P & N & W & D & G & R & A & M & D & G\end{array}$ GTG GCT GTT TTG GTC AAg AGC CTG GGG TAT AAA CCA GAg GAg tAC $\begin{array}{lllllllllllllll}\mathrm{V} & \mathrm{A} & \mathrm{V} & \mathrm{L} & \mathrm{V} & \mathrm{K} & \mathrm{S} & \mathrm{L} & \mathrm{G} & \mathrm{Y} & \mathrm{K} & \mathrm{P} & \mathrm{E} & \mathrm{E} & \mathrm{Y}\end{array}$ AAA ATG GGC AGg ACA AAg ATA TTC ATT CGG TTT CCC AAA ACC CTC $\begin{array}{lllllllllllllllllllll}K & M & G & R & T & K & I & F & I & R & F & P & K & T & L\end{array}$ TTT GCA ACA GAG GAT GCT TTA GAA GTG AGG AAG CAC AGC ATA GCA $\begin{array}{llllllllllllllll}\mathrm{F} & \mathrm{A} & \mathrm{T} & \mathrm{E} & \mathrm{D} & \mathrm{A} & \mathrm{L} & \mathrm{E} & \mathrm{V} & \mathrm{R} & \mathrm{K} & \mathrm{H} & \mathrm{S} & \mathrm{I} & \mathrm{A}\end{array}$ 
ACA TTC CTC CAG GCT AGg TGG AGA GGA TAT CAT CAA CGA CAG AAA

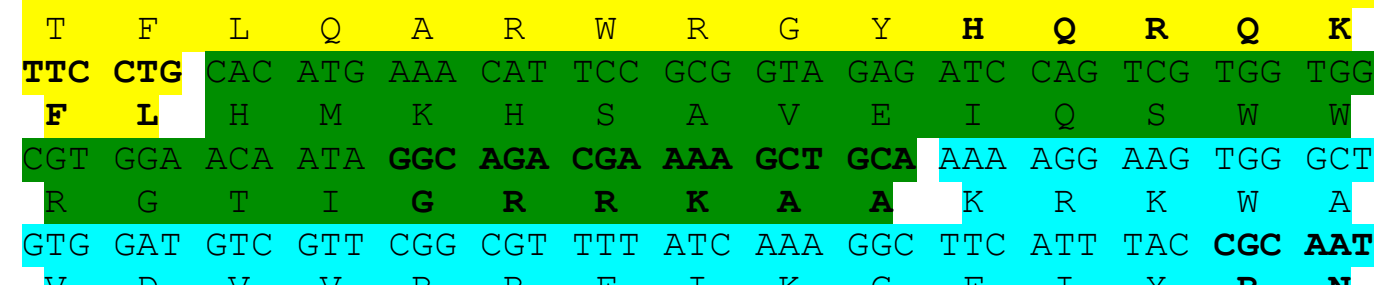

$\begin{array}{ccccccccccccccc}\mathrm{V} & \mathrm{D} & \mathrm{V} & \mathrm{V} & \mathrm{R} & \mathrm{R} & \mathrm{F} & \mathrm{I} & \mathrm{K} & \mathrm{G} & \mathrm{F} & \mathrm{I} & \mathrm{Y} & \mathbf{R} & \mathbf{N} \\ \mathrm{CAA} & \mathrm{C} & \mathrm{C} & \mathrm{C} & & \end{array}$

$\begin{array}{lllllllllllllll}\mathbf{Q} & \mathbf{P} & \mathbf{R} & \mathrm{C} & \mathrm{T} & \mathrm{E} & \mathrm{N} & \mathrm{E} & \mathrm{Y} & \mathrm{F} & \mathrm{L} & \mathrm{D} & \mathrm{Y} & \mathrm{I} & \mathrm{R}\end{array}$

TAC TCA TTC CTT ATG ACC CTC TAT CGG AAT CAG CCA AAG AGT GTG $\begin{array}{llllllllllllll}Y & S & F & L & M & T & L & Y & R & N & Q & K & S & V\end{array}$


TCT GAG CTC CTG AgG GAA ATG TGC ATG AAC AAC ATG GTG TGG AAG $\begin{array}{llllllllllllllll}S & E & L & L & R & E & M & C & M & N & N & M & V & W & K\end{array}$ TAT TGC CGC AGA ATT AAC CCT GAA TGG AAG CAA CAG TTG GAA CAG

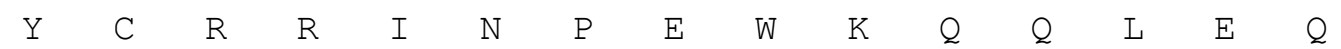
AAA GTT GTT GCC AGT GAA ATA TTC AAG GAC AAA AAA GAC AAT TAT $\begin{array}{lllllllllllllll}K & V & V & A & S & E & I & F & K & D & K & K & D & N & Y\end{array}$ CCG CAG AGT GTT CCA CGG CTT TTT ATA AAC ACA CGA CTT GGA AAT $\begin{array}{llllllllllllllll}P & Q & S & V & P & R & L & F & I & N & T & R & L & G & N\end{array}$ GAT GAA ATC AAC ACT AAA ATT CTT CAG CAA TTG GAA AGC CAG ACA $\begin{array}{llllllllllllllllllllllll}D & E & I & N & T & K & I & L & Q & Q & L & E & S & Q & T\end{array}$ TTA ACG TAT GCA GTG CCT GTA GTG AAG TAT GAC AGA AAG GGG TAC $\begin{array}{lllllllllllllll}\mathrm{L} & \mathrm{T} & \mathrm{Y} & \mathrm{A} & \mathrm{V} & \mathrm{P} & \mathrm{V} & \mathrm{V} & \mathrm{K} & \mathrm{Y} & \mathrm{D} & \mathrm{R} & \mathrm{K} & \mathrm{G} & \mathrm{Y}\end{array}$ AAG CCC CGG AGA AGA CAA CTT CTG CTC ACT CAA AAT GCT GCC TAT $\begin{array}{lllllllllllllll}K & P & R & R & R & Q & L & L & L & T & Q & N & A & A & Y\end{array}$ CTT GTT GAG GAA GCC AAA ATG AAG CAG AGG ATT GAC TAT GCT AAC $\begin{array}{lllllllllllllll}\mathrm{L} & \mathrm{V} & \mathrm{E} & \mathrm{E} & \mathrm{A} & \mathrm{K} & \mathrm{M} & \mathrm{K} & \mathrm{Q} & \mathrm{R} & \mathrm{I} & \mathrm{D} & \mathrm{Y} & \mathrm{A} & \mathrm{N}\end{array}$ CTG ACA GGA ATt TCC GTC AGC AGT CTA AGT GAC AAC CTG TTT GTT $\begin{array}{lllllllllllllll}\mathrm{L} & \mathrm{T} & \mathrm{G} & \mathrm{I} & \mathrm{S} & \mathrm{V} & \mathrm{S} & \mathrm{S} & \mathrm{L} & \mathrm{S} & \mathrm{D} & \mathrm{N} & \mathrm{L} & \mathrm{F} & \mathrm{V}\end{array}$ CTC CAT GTT AAA TGT GAA GAC AAC AAA CAA AAG GGA GAT GCA ATT

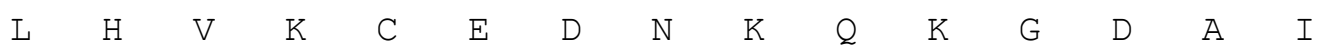
CTG CAG AGC GAT CAT GTG ATT GAA ACA CTG ACA AAA GTT GCC ATA $\begin{array}{lllllllllllllll}\mathrm{L} & \mathrm{Q} & \mathrm{S} & \mathrm{D} & \mathrm{H} & \mathrm{V} & \mathrm{I} & \mathrm{E} & \mathrm{T} & \mathrm{L} & \mathrm{T} & \mathrm{K} & \mathrm{V} & \mathrm{A} & \mathrm{I}\end{array}$ ACT GCT GAG AAA ATC AAT AAT ATC AAC ATT AAT CAG GGC AGC ATC $\begin{array}{llllllllllllllllllllllllll}T & A & E & K & I & N & N & I & N & I & N & Q & G & S & I\end{array}$ AAG TTT ACA GTT GGT CCA GGT AAA GAA GGA ATC ATT GAC TTT ACT $\begin{array}{lllllllllllllll}K & F & T & V & G & P & G & K & E & G & I & I & D & F & T\end{array}$ GCG GGC TCT GAg TTA CTA ATA GCC AAA GCA AAA AAT GGA CAC TTG $\begin{array}{llllllllllllllll}A & G & S & E & L & L & I & A & K & A & K & N & G & H & L\end{array}$ TCT GTG GTT GCT CCT CGT CTG AAT TCA CGA TGA

$\begin{array}{lllllllllll}\mathrm{S} & \mathrm{V} & \mathrm{V} & \mathbf{A} & \mathbf{P} & \mathbf{R} & \mathbf{L} & \mathbf{N} & \mathbf{S} & \mathbf{R} & \text { * }\end{array}$

Primer \# 2

GCT CCT CGT CTG AAT TCA CGA ACT AGT GAG CAG AAG CTG ATC $\begin{array}{llllllllllllll}\text { A } & \text { P } & \text { R } & \text { L } & \text { N } & \text { S } & \text { R } & \text { T } & \text { S } & \text { E } & \text { Q } & \text { K } & \text { L } & \text { I } \\ \text { AGC } & \text { GAG } & \text { GAA } & \text { GAC } & \text { CTG } & \text { TGA } & & & & & & & & \\ \text { S } & \text { E } & \text { E } & \text { D } & \text { L } & * & & & & & & & & \end{array}$

Primer \# 9 
Figure 3. Sequence of frog wild type Myosin 1c. Highlighted regions represent the primer sequences used to amplify the various truncations as outlined in Fig. 1. The numbers correspond to the primers in Table 1 in the text. The wild type and the truncated constructs have a $\mathrm{His}_{6}$ tag indicated in bold at the start of the sequence. The start codon for Myo1c is indicated in green. c-myc constructs represent the insertion of the $\mathbf{1 0}$ amino acid c-myc tag (in violet) before the stop codon in the wild type construct. 

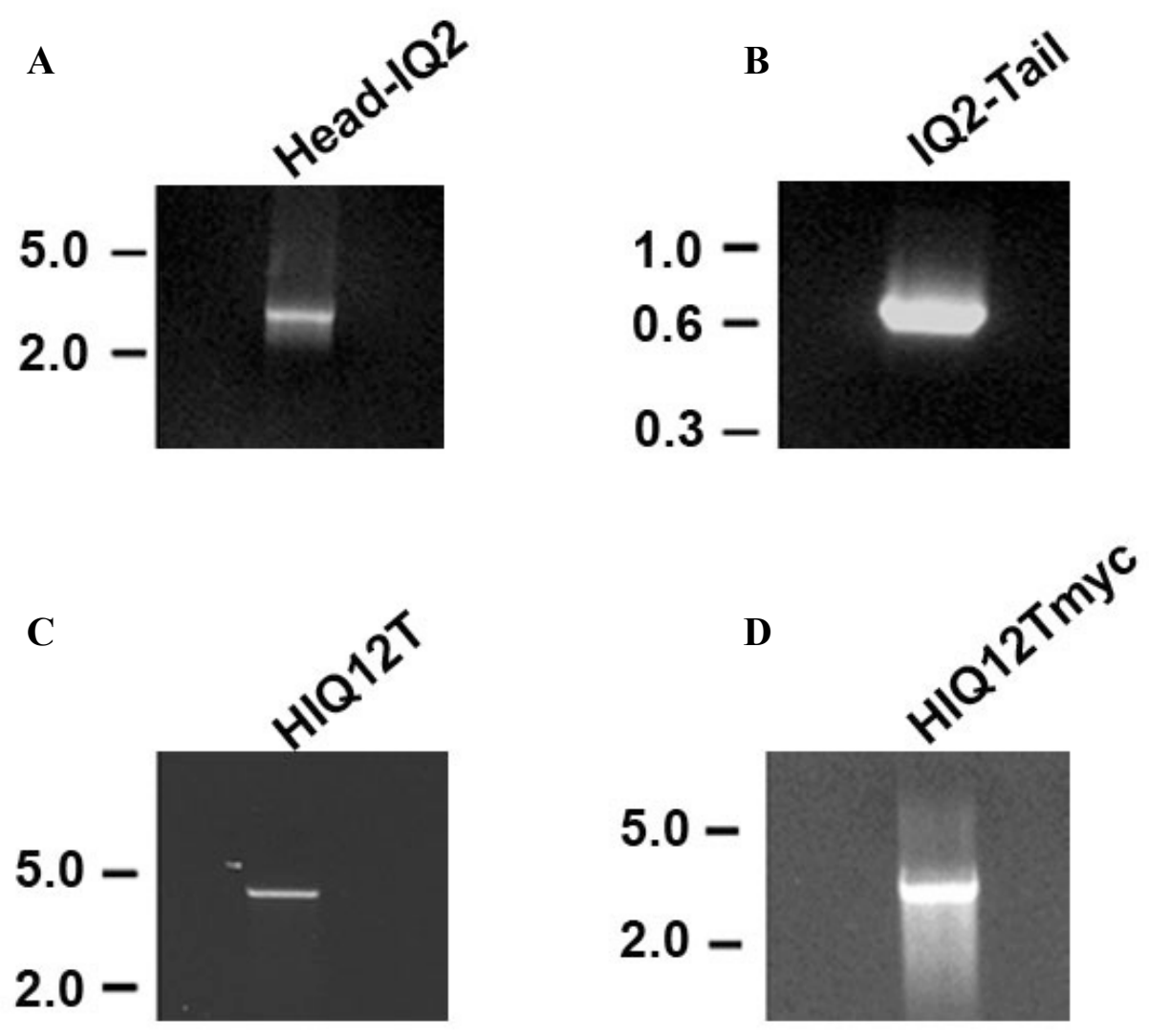

Figure 4. Ethidium bromide stained DNA gels of the truncated construct HIQ12T. HIQ12T construct consists of the head domain of Myo1c followed by IQ domains 1 and 2. A. Head-IQ2, PCR amplification of the head through IQ2 domains. Reverse primers consist of overhangs complementary to the tail; B. IQ2-tail, PCR amplification of the tail consisting of nucleotide overhangs in the forward primer complementary to the IQ2 domain; C. Purified products shown in panels A and B are combined in the PCR sewing reaction without added primers, followed by addition of primers to amplify the full insert (HIQ12T); D. To generate HIQ12Tc-myc, the HIQ12T construct is ligated to a plasmid containing the c-myc tag. The c-myc tag is inserted after the tail in the HIQ12T construct. DNA mass markers (kbp) are indicated to the left of each gel. 


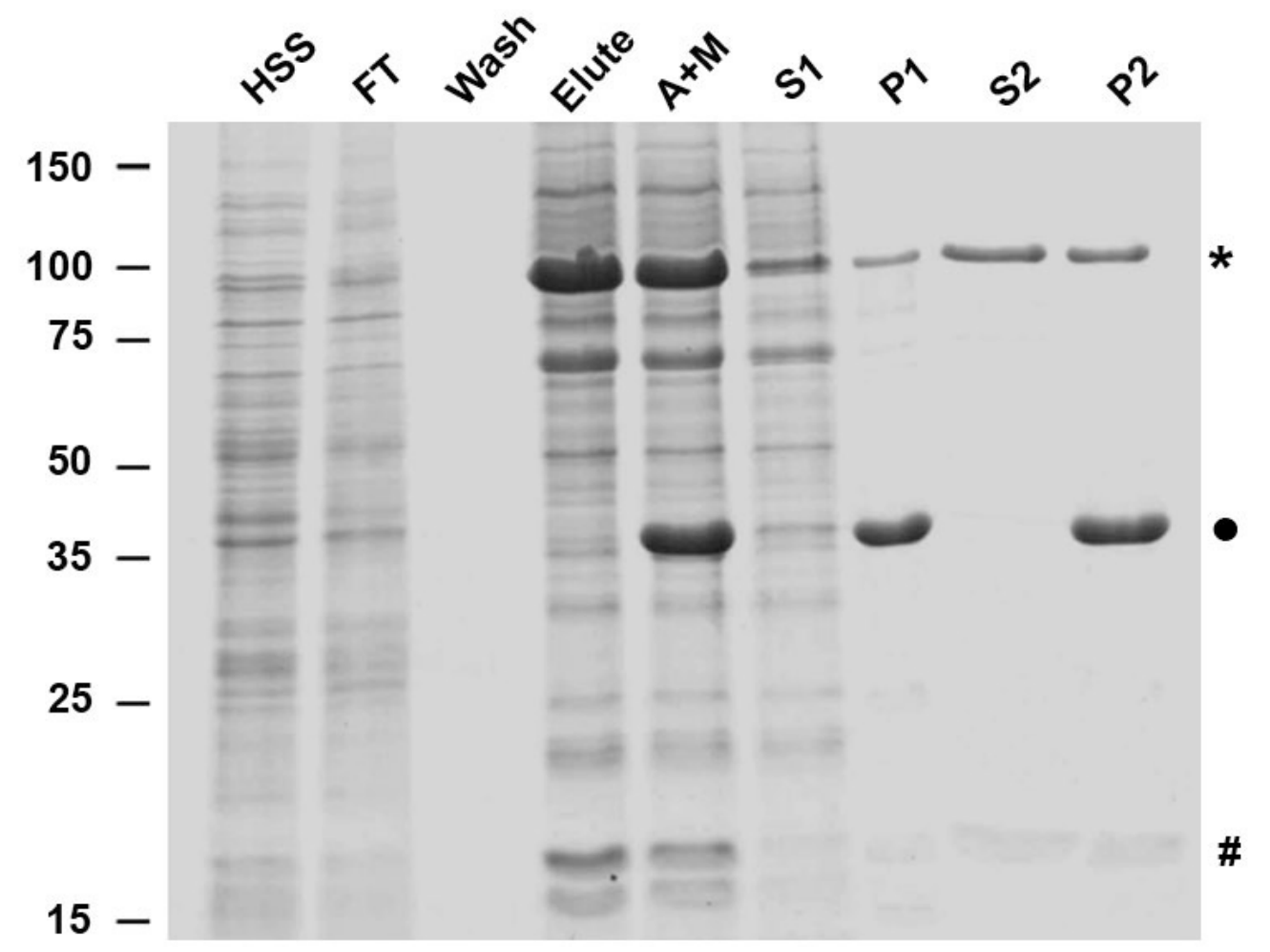

Figure 5. Purification of frog wild type Myolc: Colloidal blue stained 12\% SDSPAGE gel of wild-type Myo1c. Proteins were purified on a $\mathrm{Ni}^{2+}-\mathrm{NTA}$ column. HSS, total cell lysate after high-speed centrifugation; FT, flow through containing proteins that do not bind to the $\mathrm{Ni}^{2+}$-NTA column; Wash, proteins non-specifically bound to the column; Elute, protein from $\mathrm{Ni}^{2+}$-NTA column; $A+M$, Elute $+10 \mu M$ F-actin-Phalloidin; S1, Supernatant after centrifugation of $A+M$; P1, actomyosin pellet after centrifugation of $A+M$; S2, Myo1c released after P1 is dissolved in 5mM ATP; P2, Myo1c molecules not released by resuspension in ATP. $\left({ }^{*}\right)$ indicates Myo1c, $\left({ }^{\bullet}\right)$ indicates actin and (\#) indicates CaM. Molecular weight markers (kDa) are indicated to the left. 
A

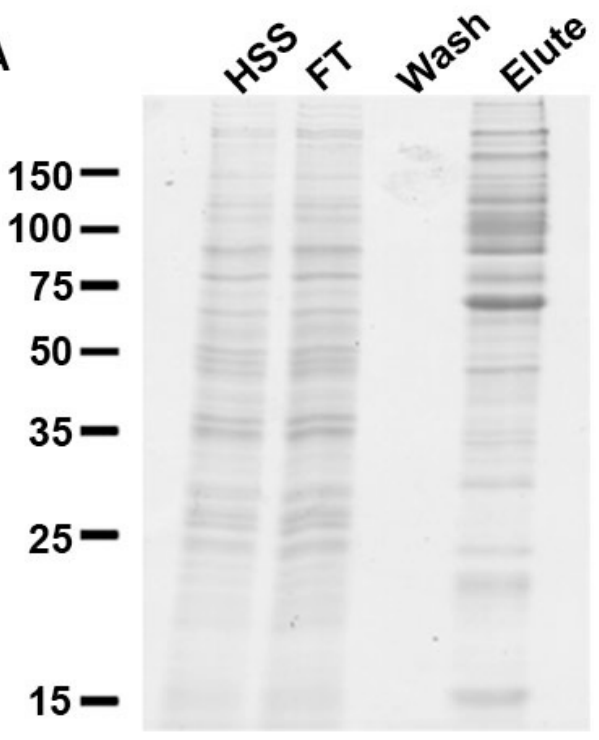

B

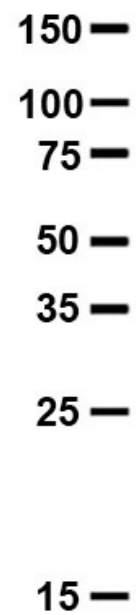

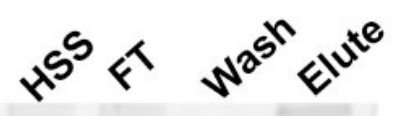

$100=$

$75-$

$50-$

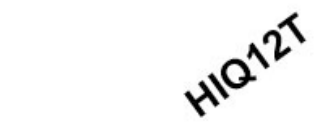

तi

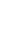




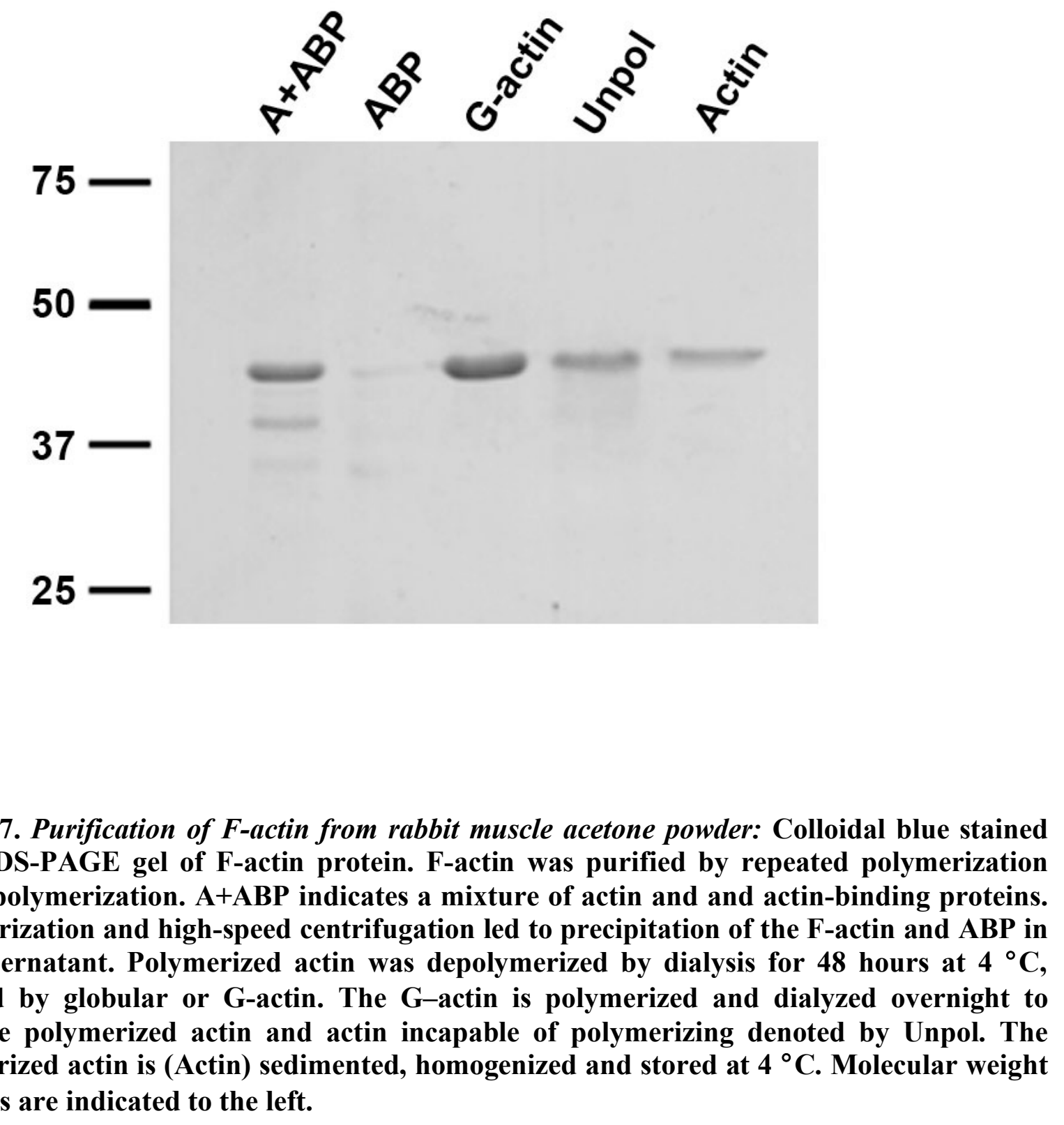

Figure 7. Purification of F-actin from rabbit muscle acetone powder: Colloidal blue stained $12 \%$ SDS-PAGE gel of $\mathrm{F}$-actin protein. $\mathrm{F}$-actin was purified by repeated polymerization and depolymerization. $\mathrm{A}+\mathrm{ABP}$ indicates a mixture of actin and and actin-binding proteins. Polymerization and high-speed centrifugation led to precipitation of the F-actin and ABP in the supernatant. Polymerized actin was depolymerized by dialysis for 48 hours at $4{ }^{\circ} \mathrm{C}$, denoted by globular or G-actin. The G-actin is polymerized and dialyzed overnight to separate polymerized actin and actin incapable of polymerizing denoted by Unpol. The polymerized actin is (Actin) sedimented, homogenized and stored at $4{ }^{\circ} \mathrm{C}$. Molecular weight markers are indicated to the left. 


\section{References}

Bahler M, Kroschewski R, Stoffler HE, Behrmann T (1994) Rat myr 4 defines a novel subclass of myosin I: identification, distribution, localization, and mapping of calmodulin-binding sites with differential calcium sensitivity. J Cell Biol 126:375-389.

Bradford MM (1976) A rapid and sensitive method for the quantitation of microgram quantities of protein utilizing the principle of protein-dye binding. Anal Biochem 72:248-254.

Cheney RE, O'Shea MK, Heuser JE, Coelho MV, Wolenski JS, Espreafico EM, Forscher P, Larson RE, Mooseker MS (1993) Brain myosin-V is a two-headed unconventional myosin with motor activity. Cell 75:13-23.

Espreafico EM, Cheney RE, Matteoli M, Nascimento AA, De Camilli PV, Larson RE, Mooseker MS (1992) Primary structure and cellular localization of chicken brain myosin-V (p190), an unconventional myosin with calmodulin light chains. J Cell Biol 119:1541-1557.

Garcia A, Coudrier E, Carboni J, Anderson J, Vandekerkhove J, Mooseker M, Louvard D, Arpin M (1989) Partial deduced sequence of the 110-kD-calmodulin complex of the avian intestinal microvillus shows that this mechanoenzyme is a member of the myosin I family. J Cell Biol 109:2895-2903.

Gillespie PG, Gillespie SK, Mercer JA, Shah K, Shokat KM (1999) Engineering of the myosin-Ib nucleotide-binding pocket to create selective sensitivity to $\mathrm{N}^{6}$-modified ADP analogs. J Biol Chem 274:31373-31381.

Horton RM, Hunt HD, Ho SN, Pullen JK, Pease LR (1989) Engineering hybrid genes without the use of restriction enzymes: gene splicing by overlap extension. Gene 77:61-68.

Huxley HE (1990) Sliding filaments and molecular motile systems. J Biol Chem 265:8347-8350.

Lin T, Tang N, Ostap EM (2005) Biochemical and motile properties of Myolb splice isoforms. J Biol Chem 280:41562-41567.

Moore JR, Krementsova EB, Trybus KM, Warshaw DM (2004) Does the myosin V neck region act as a lever? J Muscle Res Cell Motil 25:29-35.

Pardee JD, Spudich JA (1982) Purification of muscle actin. Methods Cell Biol 24: 271289

Porter JA, Minke B, Montell C (1995) Calmodulin binding to Drosophila NinaC required for termination of phototransduction. Embo J 14:4450-4459.

Purcell TJ, Morris C, Spudich JA, Sweeney HL (2002) Role of the lever arm in the processive stepping of myosin V. Proc Natl Acad Sci U S A 99:14159-14164.

Rhoads AR, Friedberg F (1997) Sequence motifs for calmodulin recognition. Faseb J 11:331-340.

Ruppert C, Kroschewski R, Bahler M (1993) Identification, characterization and cloning of myr 1, a mammalian myosin-I. J Cell Biol 120:1393-1403.

Sakamoto T, Yildez A, Selvin PR, Sellers JR (2005) Step-size is determined by neck length in myosin V. Biochemistry 44:16203-16210. 
Schott D, Ho J, Pruyne D, Bretscher A (1999) The COOH-terminal domain of Myo2p, a yeast myosin $\mathrm{V}$, has a direct role in secretory vesicle targeting. J Cell Biol 147:791-808.

Schott DH, Collins RN, Bretscher A (2002) Secretory vesicle transport velocity in living cells depends on the myosin-V lever arm length. J Cell Biol 156:35-39.

Spudich JA (1994) How molecular motors work. Nature 372:515-518.

Sundaresan V, Forgacs IC, Wight DG, Wilson B, Evan GI, Watson JV (1987) Abnormal distribution of c-myc oncogene product in familial adenomatous polyposis. J Clin Pathol 40:1274-1281.

Tanaka H, Homma K, Iwane AH, Katayama E, Ikebe R, Saito J, Yanagida T, Ikebe M (2002) The motor domain determines the large step of myosin-V. Nature 415:192195.

Uyeda TQ, Abramson PD, Spudich JA (1996) The neck region of the myosin motor domain acts as a lever arm to generate movement. Proc Natl Acad Sci U S A 93:4459-4464.

Zhu T, Sata M, Ikebe M (1996) Functional expression of mammalian myosin I beta: analysis of its motor activity. Biochemistry 35:513-522.

Zhu T, Beckingham K, Ikebe M (1998) High affinity $\mathrm{Ca}^{2+}$ binding sites of calmodulin are critical for the regulation of myosin Ibeta motor function. J Biol Chem 273:20481-20486. 


\section{Determination of ATPase activity of Myo1c}

\section{Introduction}

All known myosin proteins bind F-actin and ATP in their N-terminal motor domains and their interaction with actin is modulated by ATP binding (Barylko et al., 1992). Binding of ATP in the ATP binding cleft in the head domain causes the myosin to release the bound F-actin molecules and hydrolyze ATP to ADP and inorganic phosphate $\left(\mathrm{P}_{\mathrm{i}}\right)$. Subsequent release of the $\mathrm{P}_{\mathrm{i}}$ reorients its motor head domain exerting the powerstroke and the myosin reattaches to a new site on the actin (Lymn and Taylor, 1971). It has been shown for a number of myosins that the power stroke leads to a conformational change in the myosin lever domain that aids in the forward motion of myosins (Uyeda et al., 1996; Schott et al., 2002; Moore et al., 2004; Lin et al., 2005; Sakamoto et al., 2005).

Determination of ATPase activity of members of the myosin-1 family is fairly common and provides important insights into the enzymatic characteristics as well as regulation of this class of unconventional myosins. Among one of the well-characterized myosin-1 proteins is myosin-1b (Myo1b). It is expressed in a large variety of tissues and plays a role in membrane trafficking (Ruppert et al., 1993; Lin et al., 2005). It has six alternatively spliced isoforms containing varying numbers of IQ domains that bind CaM (Lin et al., 2005). It was found that the ATPase activities of each of theses isoforms were independent of the number of bound CaMs, however the motility along actin was linearly related to the number of CaMs associated with the IQ domains of Myolb (Lin et al., 2005), thus implying a role of the IQ domains in Myolb function. Studies in rat myosin- 
1d, another unconventional myosin containing two IQ motifs with two bound CaMs, revealed that the actin-activated and basal ATPase rates of this protein were inhibited by an increase in $\mathrm{Ca}^{+2}$ concentration (Kohler et al., 2005). Another rat Myo1 isoform termed Myole (previously called Myr 3), containing a single bound CaM, also showed decreased ATPase activity in the presence of $\mathrm{Ca}^{+2}$ (Stoffler and Bahler, 1998). Thus the regulation of motor activity for various members of the myosin-1 family varies widely and a comprehensive explanation for the basis of such variation is still lacking.

Myo1c, another widely-studied member of the myosin-1 family was first purified from the bovine brain medulla and found to have characteristics similar to other members of the myosin-1 family (Barylko et al., 1992). Its lever arm consists of four IQ consensus sequences that bind CaM (Barylko et al., 1992; Zhu and Ikebe, 1994). This was further confirmed by western blot analysis of the purified protein with anti-CaM antibodies (Barylko et al., 1992). Gel-filtration analysis of the purified protein revealed that it was a single subunit protein with 4 bound CaM light chains (Barylko et al., 1992). Because medullary tissue is also enriched in conventional MyoII, Myo1c was further purified by ion exchange chromatography followed by elution in a high potassium ion $\left(\mathrm{K}^{+}\right)$ containing buffer. Under these conditions the purified Myolc also demonstrated ATPase activity, consistent with it being an ATPase, like other myosins of its class (Barylko et al., 1992). The purified protein showed a low basal rate of $\mathrm{Mg}^{2+}$-activated ATPase reaction (1-3 nmol min$\left.{ }^{-1} \mathrm{mg}^{-1}\right)$. However the rate increased significantly upon addition of F-actin (50 $\mathrm{nmol} \mathrm{min}^{-1} \mathrm{mg}^{-1}$ ) (Barylko et al., 1992). It was also observed that free $\mathrm{Ca}^{2+}$ 
ions $(100 \mu \mathrm{M})$ also increased the basal rate of ATP hydrolysis $\left(10 \mathrm{nmol} \mathrm{min}{ }^{-1} \mathrm{mg}^{-1}\right)$ in an actin-independent manner (Barylko et al., 1992).

In an attempt to express enzymatically active recombinant Myo1c, Sf9 insect cells were infected with baculoviruses containing a bovine Myo1c insert (Zhu et al., 1996). It was observed that soluble Myo1c could only be expressed if CaM was coexpressed in the insect cells, lending credence to the fact that it was indeed an associated light chain molecule (Zhu et al., 1996). It was also reported that the CaM molecules bound to Myo1c regulate its motor properties i.e. its ATPase activity and in vitro motility (Zhu et al., 1996; Zhu et al., 1998). Consistent with previous observations, the basal ATPase activity of the recombinant Myolc increased in the presence of $\mathrm{Ca}^{2+}$, however, the actin-activated ATPase activity remained unchanged in the presence $\left(0.189 \mu \mathrm{mol} \mathrm{min}^{-1} \mathrm{mg}^{-1}\right)$ or absence $\left(0.185 \mu \mathrm{mol} \mathrm{min} \mathrm{mg}^{-1}\right)$ of $\mathrm{Ca}^{+2}$. The movement of Myolc along actin was completely abolished under conditions of high $\mathrm{Ca}^{+2}$ (Zhu et al., 1996). However, this could be reversed by adding excess exogenous CaM to the in vitro motility preparation (Zhu et al., 1996). Thus it was hypothesized that this regulation was achieved by $\mathrm{Ca}^{+2}$ binding to the $\mathrm{CaM}$ molecules associated with Myo1c IQ domains. Further support for this comes from experiments where key $\mathrm{Ca}^{2+}$-binding residues in $\mathrm{CaM}$ were mutated (Zhu et al., 1998). These mutations abolished the $\mathrm{Ca}^{+2}$ binding of $\mathrm{CaM}$ completely and provided important insights into the regulation of Myo1c, when the mutant $\mathrm{CaM}$ and Myo1c recombinant baculoviruses were co-expressed in Sf9 insect cells. Under such conditions, Myolc basal ATPase activity was unaffected by increase in $\mathrm{Ca}^{+2}$ concentration and inhibition of motility along actin was also absent in the presence of excess $\mathrm{Ca}^{+2}$ (Zhu et al., 1998). 
Expression of recombinant rat Myolc in Sf9 cells also demonstrated the actin-activated ATPase rate $\left(1 \mathrm{~s}^{-1}\right)$ of Myolc compared to its basal ATPase rate $\left(0.1 \mathrm{~s}^{-1}\right)$ (Gillespie et al., 1999; Gillespie and Cyr, 2004).

The importance of the lever arm of Myo1c has not been investigated thus far. The aim of the following experiments was to investigate the role of the lever arm length in Myo1c function. The long-term goal of these studies is to measure the basal and actinactivated ATPase assays of the mutant Myolc proteins generated in chapter II, to determine the role played by each IQ domain in Myo1c function. In the present work, analysis of the ATPase activity of frog wild type protein was performed, which acts as a control for comparing the rates of the mutants. These experiments will help us to assess the importance of the neck domain of Myolc as a lever arm. In addition, constructs were made consisting of mutations in putative CaM-binding amino acids in the individual IQ domains. These constructs will enable us to address the role of CaM bound to individual IQ domains in Myo1c function.

\section{Materials and Methods}

ATPase assay: Myolc ATPase activity was determined as described previously (Gillespie et al., 1999) in a buffer containing $15 \mathrm{mM}$ HEPES pH 7.5, $1 \mathrm{mM} \mathrm{MgCl} 2,0.1$ mM EGTA and a final $\mathrm{KCl}$ concentration of $50 \mathrm{mM}$, in the presence or absence of $25 \mu \mathrm{M}$ F-actin. Assays also included $250 \mu \mathrm{M}$ ATP (Roche, IL) containing $\gamma-{ }^{32} \mathrm{P}$ ATP (6000 $\mathrm{Ci} / \mathrm{mmol}$, GE Healthcare, NJ) to a total count of $\sim 300000 \mathrm{cpm} / \mathrm{sample}$. Each reaction was carried out in a total volume of $10 \mu \mathrm{l}$, in a siliconized $1.7 \mathrm{ml}$ microfuge tube, initiated by 
the addition of ATP. Each tube was centrifuged briefly for 5 seconds, followed by incubation at $30^{\circ} \mathrm{C}$ for 10 minutes and the reaction was terminated by the addition of a mixture of silicotungstic and sulphuric acids. The released $\gamma_{-}{ }^{32} \mathrm{P}$ was extracted into $250 \mu 1$ of a solution of benzene and isobutanol (1:1) followed by the addition of ammonium molybdate (Pollard and Korn, 1973). $100 \mu 1$ of the organic layer was counted for $\gamma_{-}{ }^{32} \mathrm{P}$ in a scintillation counter (LS 5000TD Liquid Scintillation Systems, Beckman Coulter, Fullerton, CA). Figure 1 represents the enzymatic reaction for ATP hydrolysis by Myolc. Control samples included F-actin only and ATP only in the absence of any added proteins. Myolc ATPase activity is represented as data \pm SE of at least 9 samples done in triplicates. Details of the calculation for the rates of hydrolysis are discussed in the appendix.

\section{Results and Discussion}

ATPase activity of frog wild type Myo1c: Myo1c is a mechanoenzyme that hydrolyzes ATP to produce ADP and Pi. The energy of hydrolysis is used to power movement along F-actin molecules. The goal of the present experiment was to determine the rate of ATP hydrolysis of frog wild type Myolc. We have used the recombinant wild type frog isoform of Myolc to determine its rate of hydrolysis in the presence and absence of 25 $\mu \mathrm{M}$ F-actin filaments. The $\mathrm{Ni}^{2+}$-NTA elute from the purification of wild type Myolc protein as the starting enzyme to hydrolyze ATP added was added in excess to each reaction. The number reported here is the turnover number defined as number of moles of ATP hydrolyzed per unit time per mole of enzyme. The basal Myo1c ATPase activity is

$0.15 \pm 0.03 \mathrm{~s}^{-1}$ (Table 1). In the presence of $25 \mu \mathrm{M} \mathrm{F}$-actin this increases about 8 fold to 
$1.26 \pm 0.30 \mathrm{~s}^{-1}$, thus demonstrating that the recombinant frog protein is an actin-activated ATPase. It has been demonstrated previously that Sf9 cells do not express any other actin-activated ATPase proteins (Zhu et al., 1996). Also in our hands two of the expressed mutant Myo1c proteins had no actin-activation of their ATPase rates, although they were expressed at low levels. Thus the actin-activation of Myo1c ATPase rates that we observe in our experiments is due to the functional expression of the recombinant protein.

The actin-activated rate of Myo1c reported here is slightly higher than that reported for the rat isoform $\left(1 \mathrm{~s}^{-1}\right)$ (Gillespie et al., 1999; Gillespie and Cyr, 2004) or that reported for other myosins of the same class e.g. Myo1b $\left(0.6 \mathrm{~s}^{-1}\right)$ (Lin et al., 2005). This could be due to the normalization of Myo1c concentration to the amount of active enzyme in each protein sample. We consider active Myolc to be the protein that can bind and release actin in the presence of excess ATP. Since the $\mathrm{Ni}^{2+}$-NTA elute consists of a mixture of enzymatically active and inactive Myolc molecules, the normalization of protein concentration to the amount of active enzyme is a better way to represent the data when reporting the rate of enzyme hydrolysis. It is possible that some amount of active enzyme was lost in the process of recovering active Myolc through several cycles of sedimentation. As a result these numbers are not representative of absolute rates, rather they are wild type controls which will be compared to the rates of mutant Myolc proteins as discussed in chapter II. 
ATPase activity of mutant Myo1c proteins: We analyzed a mutant Myolc protein HIQ12T as discussed in chapter II. The basal ATPase rates for this protein was very low and there was no activation of ATPase rates in the presence of $25 \mu \mathrm{M}$ F-actin. In the case of HIQ12T, it is possible that deletion of the IQ domain 3 resulted in loss of stability of the protein and thus loss of activity. It has also been shown that IQ3 domain of Myo1c binds tightly to CaM (Manceva et al., 2007). However, since the yield of HIQ12T protein was very low, it is also possible that the absence of activity was due to very low amounts of active protein initiating the reaction. At this point we decided to analyze another mutant protein FL2 as described in chapter II. This recombinant protein has mutations in key residues in the IQ2 that are predicted to cause dissociation of CaM from IQ2. It has been shown that CaM-free IQ2 domain of Myo1c can bind intracellular receptors, in a truncated Myo1c protein lacking the head domain (Phillips et al., 2006). As such we did not expect FL2 to have considerably different rates than the wild type protein, since the bound $\mathrm{CaM}$ is capable of dissociation and reassociation. However, analysis of at least two such FL2 protein pellets did not demonstrate any actin-activation of the ATPase rates. The yield of this protein was low as well and that could be a potential reason why we had no activity. Thus further optimization of expression is necessary for both of these proteins to increase the yields. Once we have satisfactory expression of these mutant proteins, we can process them similarly to the wild type control to obtain their ATPase rates. 
Table 1. ATPase activity of recombinant Myo1c

\begin{tabular}{|c|c|}
\hline Parameter & Turnover number for wild type Myo1c \\
& \\
& \\
\hline $\begin{array}{c}\text { Basal ATPase rate } \pm \text { SE } \\
+ \text { EGTA }\end{array}$ & $0.15 \pm 0.03 \mathrm{~s}^{-1}$ \\
\hline $\begin{array}{c}\text { Actin-activated ATPase rate } \pm \text { SE } \\
\text { EGTA }\end{array}$ & \\
\hline
\end{tabular}

Assayed with $250 \mu \mathrm{M}$ ATP; $25 \mu \mathrm{M}$ F-actin for actin activation 


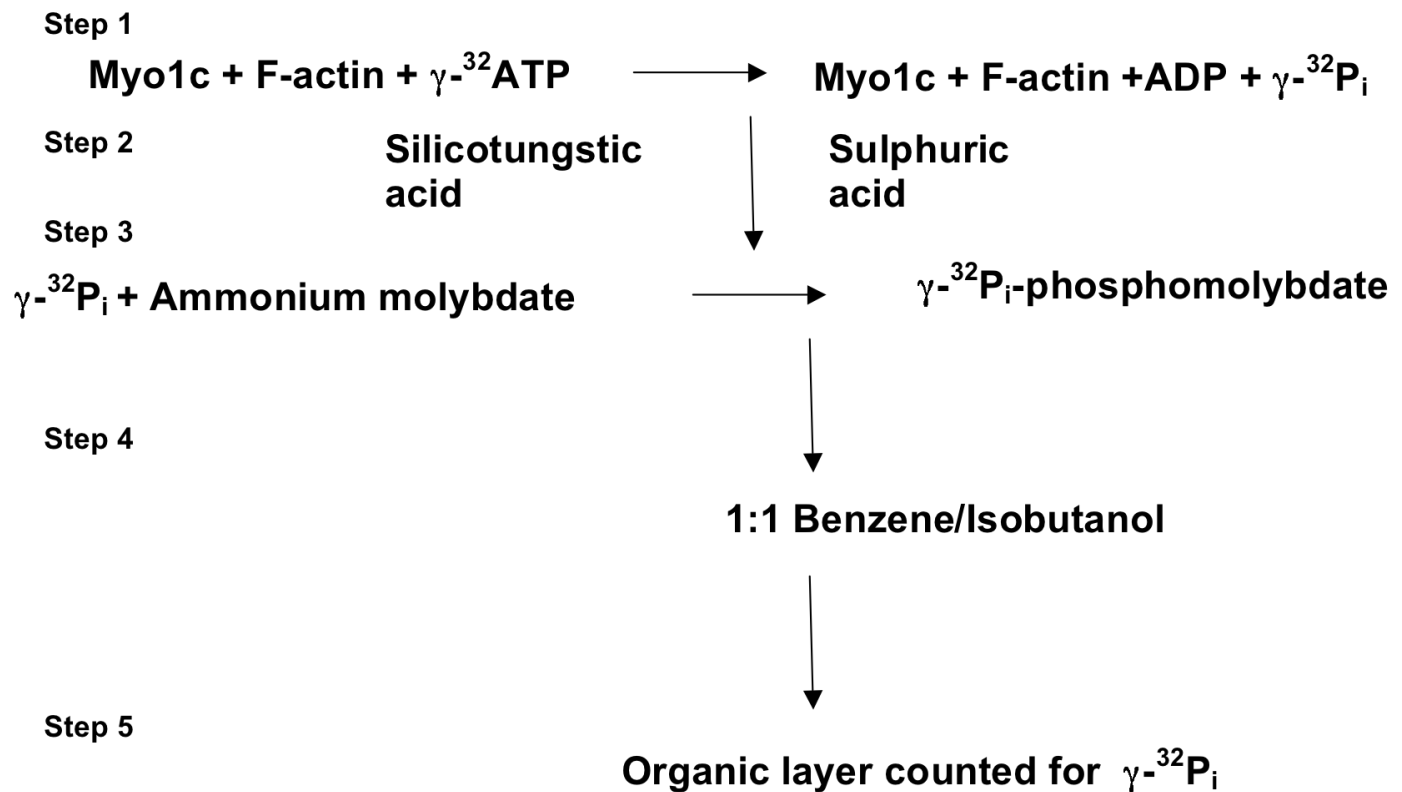

Figure 1. Hydrolysis of ATP by Myosin-1c: ATP hydrolysis is initiated by the addition of $\gamma-{ }^{32} \mathrm{P}$ ATP to a mixture of F-actin and Myo1c, forming the products ADP and $\gamma-{ }^{32} \mathrm{P}_{\mathrm{i}}$, while the enzyme Myo1c and F-actin remain unchanged step 1). The enzymatic reaction is stopped by the addition of silicotungstic and sulphuric acids (step 2). The released $\gamma-{ }^{32} \mathbf{P}_{\mathrm{i}}$ formed in step 1 is converted to $\gamma-{ }^{32} \mathbf{P}$-phosphomolybdate by the addition of ammonium molybdate solution. The $\gamma-{ }^{32} \mathrm{P}-\mathrm{phosphomolybdate} \mathrm{thus} \mathrm{formed}$ is extracted into a solution of isobutanol and benzene (step 4) and counted in a scintillation counter (step 5). 


\section{References}

Barylko B, Wagner MC, Reizes O, Albanesi JP (1992) Purification and characterization of a mammalian myosin I. Proc Natl Acad Sci USA 89, 490-494.

Gillespie PG, Gillespie SK, Mercer JA, Shah K, Shokat KM (1999) Engineering of the myosin-Ib nucleotide-binding pocket to create selective sensitivity to $\mathrm{N}^{6}$-modified ADP analogs. J Biol Chem 274:31373-31381.

Gillespie PG, Cyr JL (2004) Myosin-1c, the hair cell's adaptation motor. Annu Rev Physiol 66:521-545.

Kohler D, Struchholz S, Bahler M (2005) The two IQ-motifs and $\mathrm{Ca}^{2+} /$ calmodulin regulate the rat myosin 1d ATPase activity. Febs J 272:2189-2197.

Lin T, Tang N, Ostap EM (2005) Biochemical and motile properties of myolb splice isoforms. J Biol Chem 280:41562-41567.

Lymn RW, Taylor EW (1971) Mechanism of adenosine triphosphate hydrolysis by actomyosin. Biochemistry 10:4617-4624.

Manceva S, Lin T, Pham H, Lewis JH, Goldman YE, Ostap EM (2007) Calcium Regulation of Calmodulin Binding to and Dissociation from the Myolc Regulatory Domain. Biochemistry.

Moore JR, Krementsova EB, Trybus KM, Warshaw DM (2004) Does the myosin V neck region act as a lever? J Muscle Res Cell Motil 25:29-35.

Phillips KR, Tong S, Goodyear R, Richardson GP, Cyr JL (2006) Stereociliary myosin1c receptors are sensitive to calcium chelation and absent from cadherin 23 mutant mice. J Neurosci 26:10777-10788.

Pollard TD, Korn ED (1973) Acanthamoeba myosin. II. Interaction with actin and with a new cofactor protein required for actin activation of $\mathrm{Mg}^{2+}$ adenosine triphosphatase activity. J Biol Chem 248:4691-4697.

Ruppert C, Kroschewski R, Bahler M (1993) Identification, characterization and cloning of myr 1, a mammalian myosin-I. J Cell Biol 120:1393-1403.

Sakamoto T, Yildez A, Selvin PR, Sellers JR (2005) Step-size is determined by neck length in myosin V. Biochemistry 44:16203-16210.

Schott DH, Collins RN, Bretscher A (2002) Secretory vesicle transport velocity in living cells depends on the myosin-V lever arm length. J Cell Biol 156:35-39.

Stoffler HE, Bahler M (1998) The ATPase activity of Myr3, a rat myosin I, is allosterically inhibited by its own tail domain and by $\mathrm{Ca}^{2+}$ binding to its light chain calmodulin. J Biol Chem 273:14605-14611.

Uyeda TQ, Abramson PD, Spudich JA (1996) The neck region of the myosin motor domain acts as a lever arm to generate movement. Proc Natl Acad Sci U S A 93:4459-4464.

Zhu T, Ikebe M (1994) A novel myosin I from bovine adrenal gland. FEBS Lett 339:3136.

Zhu T, Sata M, Ikebe M (1996) Functional expression of mammalian myosin I beta: analysis of its motor activity. Biochemistry 35:513-522.

Zhu T, Beckingham K, Ikebe M (1998) High affinity Ca2+ binding sites of calmodulin are critical for the regulation of myosin Ibeta motor function. J Biol Chem 273:20481-20486. 


\begin{abstract}
APPENDIX
Analysis of percentage purity of purified Myo1c: The wild-type Myolc $\mathrm{Ni}^{2+}$-NTA elute (region of interest ROI, Fig.1 app; denoted Elute in Fig. 5, chapter II) and the functional Myo1c (Functional Myo1c, Fig. 1 app; denoted S2 in Fig. 5, chapter II), obtained after binding and releasing F-actin in the presence of ATP, were resolved on a 12\% SDS-PAGE gel. The gel was stained with Colloidal blue (Invitrogen) and scanned using a laser-based scanner (Personal Densitometer SI, Molecular Dynamics). To determine the total protein, a region of interest (ROI) was analyzed (ImageQuant, v5.2, Molecular Dynamics) as shown in dotted lines in Fig. 1 app. A graph of ROI was generated depicting each band as a peak. The area under each peak was quantified and subsequently summed to determine the total area. The peaks for Myo1c and CaM were identified by exact positioning of the cursor on the Myolc and CaM bands on the gel. The percentage of total purity represented by the Myo1c: CaM complex:
\end{abstract}

Area under the peak for Myo1c + Area under the peak for CaM

Total area under the peaks for ROI

X 100

For example, as represented in Table $1 \mathrm{app}$, the calculated percentage purity is:

$\frac{3.857+2.022}{30.572} \times 100=19 \%$

Analysis of Functional Myo1c: Myolc band (Box 2) in the $\mathrm{Ni}^{2+}-\mathrm{NTA}$ elute was compared to functional Myolc (Box 3) directly to determine the percentage of functional or enzymatically active Myolc in the $\mathrm{Ni}^{2+}$-NTA elute. Boxes of identical dimensions were drawn around the Myo1c band (Box 2) and the functional Myo1c band (Box 3). A 
third box was placed in an empty lane for background correction (Box 4). The pixel intensity for each of the boxes were quantitated with ImageQuant (v5.2, Molecular Dynamics) and the percentage of functional Myo1c was calculated as:

$\frac{\text { Pixel intensity for Box } 3}{\text { Pixel intensity for Box } 2} \times 100$

For example, as represented in Table 2 app, percentage of functional Myolc is calculated as:

$$
\frac{266.37}{1788.34} \times 100=14.8 \%
$$

Total protein concentration by Bradford assay $=0.834 \mathrm{mg} / \mathrm{ml}$

Molecular weight of Myolc $=168000 \mathrm{Da}$

Corrected concentration for functional Myolc $=0.834 \mathrm{mg} / \mathrm{ml} \mathrm{X} 0.19$ (percentage pure

Myo1c) X 0.148 (percentage functional Myo1c) $=0.022 \mathrm{mg} / \mathrm{ml}$

Molarity of functional Myo1c in Ni-NTA elute $=(0.022 / 168000) \mathrm{M}$

$$
=130 \mathrm{nM}
$$

Table 1 app: Quantitation of area under the peak

\begin{tabular}{|c|c|}
\hline \multicolumn{2}{|c|}{ Area under the peak } \\
\hline Myo1c & 3.857 \\
\hline CaM & 2.022 \\
\hline Total & 30.572 \\
\hline
\end{tabular}


Table 2 app: Calculation of pixel intensity

\begin{tabular}{|c|c|}
\hline \multicolumn{2}{|c|}{ Pixel intensity } \\
\hline Box 2 & 1788.34 \\
\hline Box 3 & 266.37 \\
\hline
\end{tabular}

Calculation of ATPase rate for wild type Myo1c: To determine the rate of hydrolysis of ATP by Myo1c, the ATPase assay is performed as described in chapter III, fig. 1. Table 3 app represents the counts in cpm in triplicates obtained by the enzymatic hydrolysis of ATP by Myo1c and other controls as indicated in each row.

Table 3 app: Counts for ATP hydrolysis

\begin{tabular}{|l|l|l|l|}
\hline \multicolumn{5}{|c|}{ Counts in cpm } \\
\hline ATP & 8477.09 & 8911.4 & 9312.47 \\
\hline Actin & 9478.29 & 9341.8 & 10307 \\
\hline Myolc & 10749 & 9783.7 & 10394 \\
\hline Actin+ Myo1c & 15518 & 14260 & 15675 \\
\hline Total counts & 332889.1 & 345936.2 & 345936.2 \\
\hline
\end{tabular}

Average (Avg) Total counts $=339413$

Total organic layer of each ATPase reaction $=250 \mu 1$

Total organic layer read $=100 \mu 1$

Total ATP in the reaction $=250 \mu \mathrm{M}$

Volume of each reaction $=10 \mu 1$

$$
\begin{array}{r}
\text { Total count }=\frac{339413 \mathrm{cpm} \mathrm{X} 1000}{250 \mu \mathrm{M} \times 10 \mu \mathrm{l}} \quad \mathrm{X} \quad \frac{100 \mu \mathrm{l}}{250 \mu \mathrm{l}} \\
=54306 \mathrm{cpm} / \mathrm{nmol} \text { of ATP }
\end{array}
$$


Avg ATP count $=8900 \mathrm{cpm}$

Avg actin count $=($ Actin counts - Avg ATP counts $)$

$$
=809 \mathrm{cpm}
$$

ATP hydrolysed (in nmol) by Myo1c alone (basal/ no Actin):

Avg Myolc counts in cpm - 8900 cpm $54306 \mathrm{cpm} / \mathrm{nmol}$

ATP hydrolysed (in nmol) by Myo1c + Actin (actin-activated):

Avg Actin + Myo1c counts in cpm - 8900 cpm - 809 cpm $54306 \mathrm{cpm} / \mathrm{nmol}$

Total reaction time $=10 \mathrm{~min}$

The Ni-NTA elute was diluted 1:1 with elution buffer without $\mathrm{KCl}=0.022 \mathrm{mg} / \mathrm{ml} / 2$

$$
=0.011 \mathrm{mg} / \mathrm{ml}
$$

Volume of Myo1c used per reaction $=2.5 \mu \mathrm{l}$

Molecular weight of Myo1c $=168000 \mathrm{Da}$

ATP hydrolysed (in nmol) per minute per mg of Myo1c (actin-activated)

$0.1002 \mathrm{nmol}$

$0.0025 \mu 1 \mathrm{X} 0.011 \mathrm{mg} / \mathrm{ml}$ X $10 \mathrm{~min}$

Turnover number or moles of ATP hydrolysed per second per mole of Myo1c

$$
\begin{aligned}
\frac{364.4 \mathrm{nmol} / \mathrm{min} / \mathrm{mg} \mathrm{X} 10^{-9} \times 10^{-3} \times 168000 \mathrm{~g}}{60 \mathrm{sec}} & =1.02 \mathrm{~mol} / \mathrm{sec} / \mathrm{mol} \\
& =1.02 \mathrm{~s}^{-1}
\end{aligned}
$$






Figure 1 app: Determination of percentage purity and percentage functional Myo1c. Colloidal blue stained 12\% SDS-PAGE gel of wild type Myo1c. Myo1c $\mathrm{Ni}^{2+}$-NTA elute is denoted as ROI in the text. The Myo1c band is denoted as Box 2. Box 3 depicts the functional Myo1c band and Box 4 represents the background correction for boxes 2 and 3. $\mathrm{CaM}$ is indicated to the right of the gel. Molecular weight markers are indicated (in $\mathrm{kDa}$ ) to the left. 


\title{
Curriculum Vitae
}

\author{
Anindita Biswas
}

\section{Home address}

1056 Van Voorhis Road

Apt K120

Morgantown, WV 26505

telephone: (304) 2933848

(304) 3760243

Citizenship: India

\section{University address}

Department of Biochemistry

West Virginia University School of

Medicine

1 Medical Center Drive

Morgantown, WV 26506

telephone: (304) 2935253

email: abiswas1@mix.wvu.edu

\section{Educational Qualifications:}

- 2003-Present: Graduate student, Laboratory of Dr. Janet L. Cyr

Department of Biochemistry, WVU School of Medicine

Tentative graduation date: Fall (Dec) 2007.

GPA 3.74

Research Project: Analysis of motor activity of recombinant Myosin-1c

- 2000-2002: MS, Biochemistry, University of Calcutta, India.

- 1997-2000: BS, Chemistry (major) with Physics and Mathematics (minors), University of Calcutta, India.

\section{Appointments:}

- 2002-2003: Research assistant, Department of Biochemistry, University of Calcutta, India. 


\section{Abstracts presented:}

- Kelli Phillips, Anindita Biswas, Janet Cyr* (2005). The role of Myosin-1c's calmodulin-binding domains in binding to hair bundle receptors. Assoc. Res. in Otolaryngol. Abs. \#895

- Anindita Biswas*, Song Tong, Janet Cyr (2006). Designing truncated constructs of myosin-1c to test their ATPase activities. WVU Center for Neuroscience Annual Retreat.

\section{Technical skills:}

- PCR

- General cell culture techniques

- Insect cell culture

- Cloning using bacterial systems

- Transient transfection in tissue culture cells

- Expression of proteins in bacteria

- Purification of recombinant proteins using nickel-nitriloacetic acid column

- Gel filtration chromatography

- SDS PAGE

- Western blotting

- Limited experience in immunofluorescence using confocal microscopy

- Immunoprecipitation/Pull down assays

- Enzyme assay

\section{Teaching Experience:}

Biochemistry 339 laboratory (Introduction to Biochemistry; \# of contact hours: 2) CCMD 730 Human function (First year Medical Students; \# of contact hours: 1) 